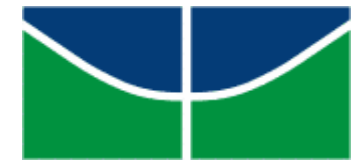

UNIVERSIDADE DE BRASÍLIA

INSTITUTO DE PSICOLOGIA

Programa de Pós-Graduação em Psicologia Clínica e Cultura - PPG PsiCC

ADOLESCENTES EM SITUAÇÃO DE OFENSA SEXUAL INTRAFAMILIAR:

CONHECER E INTERVIR PARA PREVENIR A REINCIDÊNCIA

Daniela Fontoura Domingues

Brasília, junho de 2016 


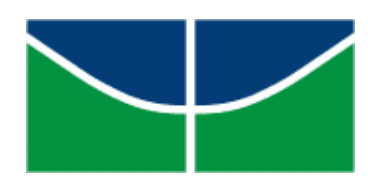

UNIVERSIDADE DE BRASÍLIA

INSTITUTO DE PSICOLOGIA

Programa de Pós-Graduação em Psicologia Clínica e Cultura - PPG PsiCC

\title{
ADOLESCENTES EM SITUAÇÃO DE OFENSA SEXUAL INTRAFAMILIAR: CONHECER E INTERVIR PARA PREVENIR A REINCIDÊNCIA
}

\author{
Daniela Fontoura Domingues
}

Tese de doutorado apresentada ao Programa de Pós-Graduação em Psicologia Clínica e Cultura PPG PsiCC - do Instituto de Psicologia da Universidade de Brasília - IP/UnB, como parte dos requisitos necessários à obtenção do título de Doutor em Psicologia.

Orientadora: Profa. Dra. Liana Fortunato Costa 
Ficha catalográfica elaborada automaticamente, com os dados fornecidos pelo(a) autor(a)

Domingues, Daniela Fontoura
Adolescentes em Situação de ofensa Sexual
Intrafamiliar: Conhecer e Intervir para Prevenir a
Reincidência / Daniela Fontoura Domingues;
orientador Liana F. Costa. - Brasilia, 2016.
175 p.
Tese (Doutorado - Doutorado em Psicologia Clínica
e Cultura) -- Universidade de Brasilia, 2016.
1. ofensa sexual. 2. adolescência. 3. sistema
familiar. 4. reinciência. 5. prevenção. I. Costa,
Liana F., orient. II. Título.




\section{Universidade de Brasília - UnB \\ Instituto de Psicologia - IP \\ Programa de Pós-graduação em Psicologia Clínica e Cultura}

Esta tese foi aprovada pela seguinte Banca Examinadora:

Profa. Dra. Liana Fortunato Costa
Presidente
Universidade de Brasília - UnB

Profa. Dra. Martha Giudice Narvaz

Membro externo

Universidade Estadual do Rio Grande do Sul - UERGS

Profa. Dra. Cristina Zackseski

Membro externo

Universidade de Brasília - Direito UnB
Prof. Dr. Anderson Pereira de Andrade
Membro externo

Promotor de Justiça - MPDFT

Profa. Dra. Silvia Renata M. Lordello

Membro interno

Universidade de Brasília - PPG PsiCC UnB

Profa. Dra. Maria Aparecida Penso

Membro suplente

Universidade Católica de Brasília - UCB 


\section{RESUMO}

A ofensa sexual, também denominada abuso sexual, cometida por adolescentes, é um fenômeno complexo e heterogêneo que atinge pessoas de diferentes credos, etnias, nível educacional e status socioeconômico. É um tema ainda pouco investigado no território brasileiro e desconhecido em termos estatísticos, diferentemente do contexto internacional. Assim, este estudo teve por objetivo conhecer características, ambientes e relações de adolescentes em situação sexual ofensiva intrafamiliar, bem como identificar os fatores de risco e a perspectiva de futuro destes jovens para prevenir a reincidência. Trata-se de um estudo qualitativo, construído com base na perspectiva sistêmica, cujos pressupostos são a complexidade, a intersubjetividade e a contextualização. A pesquisa foi conduzida com quatro adolescentes entre 12 e 18 anos de idade e suas famílias - mães ou responsáveis pelos jovens - atendidos em uma unidade de saúde mental infanto-juvenil, que compõe a Rede de Proteção a Crianças e Adolescentes do Distrito Federal. A coleta de dados ocorreu nas dependências desta unidade, que oferece atendimento e intervenção na modalidade de Grupo Multifamiliar (GM), tanto para vítimas, quanto para perpetradores de violência sexual. Três instrumentos foram empregados no estudo: 1) uma entrevista semiestruturada construída e já utilizada pela equipe de profissionais da instituição; 2) o checklist ERASOR - Estimativa de Risco de Reincidência de Agressão Sexual em Adolescentes (em versão adaptada para a língua portuguesa); e 3) um recurso gráfico para que o adolescente representasse, através de desenho e verbalmente, sua perspectiva de futuro. A entrevista se centrou em aspectos da história pregressa das famílias, circunstâncias em que ocorreram os eventos, consequências para o grupo familiar, medidas adotadas pelos responsáveis e instituições a que recorreram após o fato. O checklist focalizou diferentes fatores de risco para a reincidência, tais como o histórico de ofensas sexuais do adolescente, seu funcionamento psicossocial e o funcionamento familiar e ambiental. O recurso gráfico serviu para explorar a visão do adolescente sobre sua trajetória futura. A análise dos dados revelou que a violência, no contexto intra e extrafamiliar, favoreceu as situações de ofensa sexual, cuja responsabilidade pelo ato foi atribuída à vítima e minimizada pelo autor da ofensa. Quanto à reincidência, além dos fatores de risco do checklist, foi constatado que prévia vitimização sexual vivenciada por dois dos adolescentes contribuiu para a prática sexual ofensiva, tendo em vista que esta experiência não foi completamente elucidada e, tampouco, tratada. Em consonância a tais resultados, os jovens expressaram temor e ambivalência em relação ao processo de superação dos episódios ofensivos e à sua trajetória, especialmente pelo fato de pertencerem a famílias com pouca disponibilidade protetiva. Por outro lado, também foram detectadas perspectivas de futuro positivas e otimistas. Trata-se, portanto, de um problema que se refere a todos os membros do sistema familiar e que precisa ser trabalhado de forma integrada e global. Depreende-se que essa população necessite de políticas públicas eficientes, de serviços de saúde adequados e de um sistema de justiça juvenil ágil e apoiador, pois, o adolescente em situação de ofensa sexual intrafamiliar carece de atenção e intervenção especializada para prevenir a repetição do ato violento e trilhar um novo caminho.

Palavras-chave: ofensa sexual, adolescência, perspectiva sistêmica, reincidência, prevenção 


\begin{abstract}
Sexual offense, also called sexual abuse, committed by adolescents is a complex and heterogeneous phenomenon that affects people of different beliefs, ethnicities, educational backgrounds and socioeconomic status. It is a topic little explored in Brazil and which lacks statistical data, unlike what happens in the international scenario. This study was designed to examine the characteristics, environments and relationships of adolescents in intrafamily sexually abusive situations. It also aims at identifying the risk factors and the future prospects of these youths to prevent recidivism. This is a qualitative study, built on the systemic perspective, whose assumptions are complexity, intersubjectivity and contextualization. The research was conducted with four teenagers between 12 and 18 years of age, as well as with their mothers and/or guardians. The setting was a child and adolescent mental healthcare unit, which comprise the Children and Adolescent Protection Network of Brazil's Federal District. Data collection took place on the premises of this unit which provides Multi-family group therapy (MFGT), both for the victims and sexual offenders. Three instruments were used in the study: 1) a semi-structured interview that had been built and used by the professional staff of that unit; 2) the "ERASOR" - Estimative of Risk Adolescent Sexual Offense Recidivism checklist (Portuguese version); and 3) a graphic resource to elicit the teenagers' future prospects. The interview focused on the history of the family, circumstances in which the events occurred, consequences for the family group, measures adopted by the people responsible for the adolescents, and the institutions they resorted to after the abusive events. The ERASOR checklist was completed by the professionals focusing on different risk factors for reoffense, such as the history of sexual offenses committed by adolescents, as well as their psychosocial and family/environmental functioning. The graphic resource was meant to explore the teenagers' views through the drawing of their future perspectives. Data analysis revealed that violence, inside and outside the family, favored sexual offense situations, in which responsibility for the act was attributed to the victim and minimized by the perpetrator of the offense. As far as the reoffense potential is concerned, the analysis suggests that the offenders themselves had suffered sexual abuse. Such is the case of two subjects. Prior sexual abuse suffered by these offenders has not been completely unraveled, neither treated. In line with these results, young people's drawings expressed fear and ambivalence about the process of overcoming the prevailing offensive episodes and their history, especially because they belong to families with little protective availability. On the other hand, potential positive and optimistic outcomes were detected. Juvenile sexual offense is a problem that concerns all members of the family and requires to be dealt with in an integrated and comprehensive manner. These individuals need efficient public policies, adequate healthcare and an agile and supportive juvenile legal system. Adolescents in intrafamily sexual offense situation needs attention and specialized intervention to prevent reoffense and choose a new path.
\end{abstract}

Keywords: sexual offense, adolescence, systemic perspective, recidivism, prevention 


\section{AGRADECIMENTOS}

Agradeço, primeiramente, aos adolescentes e suas famílias que tornaram possível a realização desse estudo.

Aos profissionais do COMPP - Centro de Orientação Médico Psicopedagógica da Secretaria de Saúde do Governo Distrito Federal - pela colaboração e parceria: Denise Marreco, Eika Junqueira, Júlia de Barros, Lucy Mary Stroher e Marialice Chaves.

À minha orientadora, Profa. Dra. Liana Fortunato Costa, pela atenção, carinho e dedicação durante os quatro anos dessa jornada.

À minha orientadora do mestrado, Profa. Dra. Maria Auxiliadora Dessen, onde tudo começou.

Aos professores, Martha Giudice Narvaz, Cristina Zackseski, Silvia Renata M. Lordello, Maria Aparecida Penso e ao Dr. Anderson Pereira de Andrade, que aceitaram participar da banca e compartilhar seu conhecimento e experiência.

À Profa. Dra. Ângela Costa Maia e ao Professor Dr. Rui Abrunhosa Gonçalves, por terem gentilmente me recebido na Universidade do Minho, em Braga, Portugal.

À parceira e amiga Patrícia Cristina Campos-Ramos que esteve presente comigo durante todo o percurso. E por suas infinitas e maravilhosas contribuições...

À Amilcar D’Avila de Mello, por sua disponibilidade e colaboração.

Aos amigos, Beatriz Vargas, Lélia Almeida, Ana Carolina Villas Boas, Simone Cerqueira da Silva, Sylvia Senna, Iara Muller Portella, Roberto Castilhos, Ana Maria Kalil, Luiza Morais, Grabriela Nassif Azen, Nalva Clemente, Vânia Marques, Carol Velho, Carmen Souto, Mirna Petrovich, Ziza De Toni, Patrícia Markus e Mardiori Pinheiro, pela força e incentivo. 
Ao colega e às colegas, Marlene M. Marra, Márcia R. dos Santos, Juliana Castro, Mariana Juras, Andrea Lagares, Amanda Said e Wladimir Perreca, pelo apoio e pelas conquistas compartilhadas.

Ao Programa de Pós-graduação em Psicologia Clínica e Cultura da UnB e a todos os seus funcionários, que me auxiliaram nos diferentes momentos.

À Coordenação de Aperfeiçoamento de Pessoal de Nível Superior CAPES e à Universidade de Brasília, pelo apoio financeiro e institucional, respectivamente.

Aos queridos, Pedro Tirelli, Laura Tirelli, Guillermina Peñaloza e ao companheiro Mário César Tirelli, por todos os momentos!!!! 
"Mais do que nunca, sinto que a raça humana é somente uma. Há diferenças de cores, línguas, culturas e oportunidades, mas os sentimentos e reações das pessoas são semelhantes. Pessoas fogem das guerras para escapar da morte, migram para melhorar sua sorte, constroem novas vidas em terras estrangeiras, adaptam-se a situações extremas..." Sebastião Salgado 


\section{SUMÁRIO}

Apresentação

Introdução

Políticas de Enfrentamento à Violência Sexual para Vítimas e Autores _.................. 18

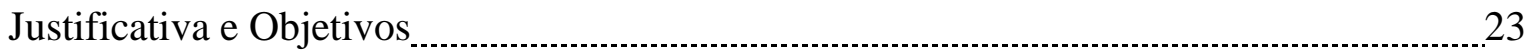

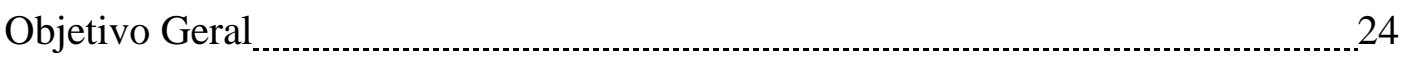

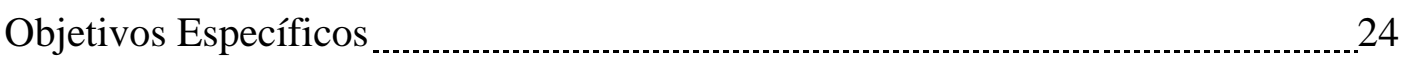

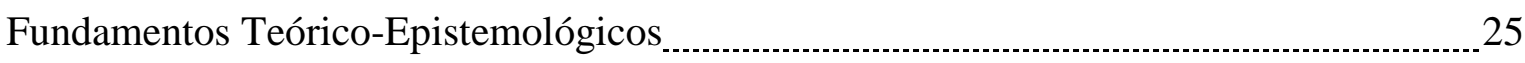

O Pensamento Sistêmico

Adolescência e Sexualidade: Da Prática Normativa ao Ato Sexual Ofensivo _........ 28

Ofensa Sexual/Abuso sexual 31

A Família do Adolescente que Comete Ofensa Sexual: Contexto e Adversidades 35

Adolescentes que Cometeram Ofensa Sexual: Análise Documental em

Processos Judiciais

Adolescente Considerado Autor de Ofensa Sexual: Proteção, Responsabilização

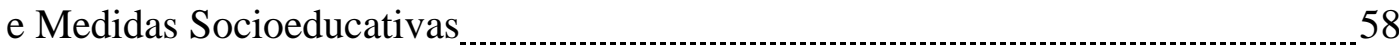

Ofensa sexual Perpetrada por Adolescentes: Percurso e Intervenção no

Contexto Português e no Brasileiro

Método

Pesquisa Qualitativa

O Contexto Institucional

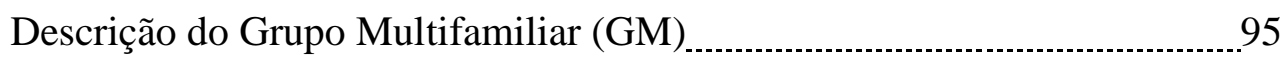

Fluxo do Grupo Multifamiliar

Critérios de Inclusão no Grupo Multifamiliar _..............................98

Participantes do Estudo.

Instrumentos $\quad 100$

Etapas da Pesquisa e Inserção no Ambiente Institucional _........................ 103

Limitações Institucionais para a Realização da Pesquisa _............... 104

Cuidados Éticos

Procedimentos para Análise dos Dados

Estágio Sanduíche

Resultados 
1. Entrevistas: História dos Adolescentes e Sistemas de Categorias 107

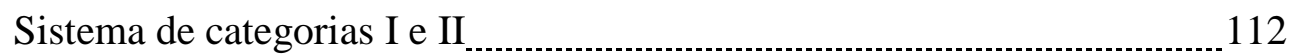

2. Checklist ERASOR 120

3. Figura 122

Discussão

Considerações Finais

Referências

Anexos 171

\section{Lista de Tabelas}

Tabela 1: Categorias definidas para a pesquisa nos processos _............................ 48

Tabela 2: Levantamento do número de processos entre 2008 e 2013

Tabela 3: Características dos adolescentes, das vítimas e do contexto _..................49

Tabela 4: Características do adolescente e dados sobre o ato sexual ofensivo ........99

Tabela 5: Caracterização das famílias do adolescente que cometeu ato sexual ofensivo ...99

Tabela 6: Dados sociodemográficos dos familiares/responsáveis pelo adolescente 100 ...

Tabela 7: Motivo do encaminhamento, instituições envolvidas, o tempo

entre a denúncia e o atendimento do adolescente e sua idade ............................. 111

Tabela 8: Sistema de categorias I e I 


\section{APRESENTAÇÃO}

A construção da presente tese é fruto de um processo de reflexão que teve início em 2002, época em que comecei a trabalhar como psicóloga em uma instituição prisional. Embora tivesse concluído a graduação nove anos antes, foi a partir desta oportunidade que passei a questionar uma série de aspectos da minha formação, o aprendizado acadêmico, as crenças sobre saúde $\mathrm{x}$ doença e, principalmente, os valores que norteavam o rumo da minha carreira. O relato que apresento nos próximos parágrafos mostra alguns episódios referentes a esse processo e os caminhos adotados desde então.

A referida instituição, localizada no Rio Grande do Sul, era de médio porte e destinada a presos do sexo masculino, que cumpriam pena em regime fechado. Mesmo sem ter planejado atuar em um estabelecimento carcerário e sem prévia experiência na área, o trabalho durou cerca de três anos e gerou, além de mudanças pessoais e profissionais, novos desafios. O primeiro deles disse respeito ao enfrentamento de adversidades, como condições de trabalho insalubres, carga horária excessiva, baixa remuneração e risco de vida.

Por outro lado, foi um local de trocas e crescimento. Nesse ambiente descobri, por exemplo, motivação para investigar dois assuntos inquietantes e pouco explorados pela literatura científica brasileira, sob o ponto de vista da Psicologia: a morte de jovens vitimados por homicídio - que resultou em minha dissertação de mestrado - e a ofensa sexual perpetrada por jovens, foco do presente estudo.

Mas nada aconteceu ao acaso. Quando ingressei como servidora fui designada para atender a ala de presos condenados por delito sexual, pelo fato de ter especialização na área de violência doméstica. Sabia que o conteúdo aprendido no curso seria insuficiente para lidar com a situação e que precisaria adquirir novas habilidades e conhecimento. Foi um começo bastante difícil e com muitas noites mal dormidas, pesadelos e vontade de abandonar o 
ofício. De qualquer modo, queria estar ali e me aproximar do assunto. Resolvi deixar de lado os preconceitos e o medo para tentar compreender a dinâmica daqueles homens, de diversas idades, que haviam cometido violência sexual em distintos contextos e contra vítimas de zero a 80 anos.

Todos eles, na minha imaginação, eram valentes, fortes, corajosos e com autoestima elevada. Deveriam, em princípio, ter um mesmo tipo de comportamento e estilo de comunicação. Porém, no dia a dia do trabalho e a cada novo encontro, muitas surpresas e decepções. Aquelas pessoas à minha frente não se pareciam com os vilões dos filmes e, tampouco, o enredo de suas vidas se assemelhavam às histórias dos jornais. Comecei a entender que nada sabia e a desconstruir noções equivocadas.

Deixei-me guiar pela escuta, pela vontade de ouvir o que eles tinham a dizer, sem exigências maiores, simplesmente estando ali. Naquela altura, a missão da Psicologia passava pelo acompanhamento de cada perpetrador com o intuito de auxiliar no cumprimento da pena. $\mathrm{O}$ profissional tinha a tarefa de preparar o sujeito para a progressão de regime (do meio fechado para o meio semiaberto ou aberto), de modo a promover sua reinserção social e evitar a reincidência.

Tal prática, todavia, foi se mostrando bastante complexa e, à medida que o tempo foi passando, entendi que a pessoa presa tem autonomia para decidir sua vida intramuros e liberdade para optar entre ser ouvida ou não. Muitos apenados, inclusive, evitavam a equipe e ficavam receosos de fornecer dados a seu respeito, de falar sobre o seu passado ou firmar qualquer vínculo com os funcionários.

Naquele espaço, o trabalho dos técnicos era realizado de modo lento e intercalado. O cenário não favorecia o diálogo, não permitia privacidade; pelo contrário, incentivava a desconfiança. Por medida de segurança, todos os presos compareciam algemados ao atendimento e a falta de mobilidade ajudava a criar um clima pesado e nada criativo. 
Aos poucos compreendi que havia um jogo de forças entre o indivíduo preso, o profissional e a instituição, cuja relação de poder delimitava a prática. Enfim, a rotina era organizada de um jeito muito distante ao do ideal. Dentro de mim uma voz falava baixinho: “deixa de ser exigente, cai na real, aqui não é o paraíso". Precisei rever minhas metas e me adaptar aos recursos disponíveis para as coisas começarem a acontecer.

Meu primeiro cliente foi um homem de 24 anos, muito magro e tímido, chamado M., condenado mais de uma vez por estupro. Tive uma conexão com ele logo de imediato; não tive receio, nem raiva, nem nojo. No primeiro dia expliquei quem eu era, o que fazia ali e apresentei a proposta de conversarmos quinzenalmente. Ele topou e o atendimento ocorreu durante muitos meses, ao contrário da minha expectativa inicial. Nesse período, falamos sobre sua vida, sobre episódios de violência, vivências de abandono, dor, medo e insegurança. M. permitiu que eu fizesse contato com sua única referência fora da prisão: sua avó materna. Interessou-se pela escola e voltou a estudar.

Depois de M., outros homens vieram para o atendimento. Todos muito diferentes e, ao mesmo tempo, parecidos. Dessa experiência, ficou a vontade de fazer mais, de recomeçar a estudar e agir precocemente na história destes "meninos". Entendi que se trata de uma população heterogênea e que no ambiente fechado, como em situação de privação de liberdade, é difícil abordar de modo eficiente a pessoa que comete crimes de natureza sexual.

Ainda assim, creio que um laço de humanidade estabelecido durante o processo interventivo pode gerar bons resultados e, o quanto antes isso for feito, melhor. As recordações dos atendimentos e o desejo de pesquisar sobre a história, a trajetória e o comportamento desses indivíduos, sobretudo na adolescência e na juventude, serviram de incentivo para a escolha do objeto de estudo desta tese: o adolescente em situação de ofensa sexual. A parceria firmada com a professora/orientadora Dra. Liana Fortunato Costa, 10 anos após o meu primeiro contato com o fenômeno da violência sexual, também foi 
decisiva para a construção da investigação e pelo percurso percorrido.

A tese, a seguir apresentada, é formada por duas partes: uma é composta pelas políticas de enfrentamento à violência sexual, pela introdução dos fundamentos teóricos que norteiam o trabalho, as justificativas, os objetivos e o método; outra parte, empírica, inclui os resultados, a discussão e as conclusões. O texto apresenta também três artigos - a serem submetidos a publicação. O primeiro deles mostra um levantamento realizado em processos na Vara da Infância e da Juventude no Distrito Federal; o segundo trata de questões relativas à proteção, responsabilização e às medidas socioeducativas destinadas a adolescentes autores de ofensa sexual; e o terceiro discute as possibilidades interventivas para adolescentes no contexto português e no brasileiro, após episódios ofensivos. Este último é fruto do período de estágio sanduíche realizado na Universidade do Minho, em Braga, Portugal. 


\section{INTRODUÇÃO}

Nas últimas décadas, uma combinação de fatores relativos à globalização, ao desemprego, às migrações e à escassez de recursos naturais tem gerado uma transformação social, econômica e ambiental de caráter mundial (Porto, 2010). A sociedade brasileira - a exemplo de outras do contexto internacional - vive um momento de crise que afeta não apenas as instituições, mas também diferentes grupos sociais, famílias e indivíduos. Os efeitos da crise são nítidos, particularmente entre a camada jovem. Chama a atenção, por exemplo, o número de adolescentes que, além de sofrer as pressões macrossociais, enfrenta uma série de dificuldades relativas à falta de cuidados básicos de saúde, segurança e proteção (Barber-Madden \& Saber, 2010).

Segundo documento do Fundo das Nações Unidas para a Infância - UNICEF (2011), o Brasil tem atualmente uma população de mais de 21 milhões de adolescentes entre 12 e 17 anos, sendo que $38 \%$ destes vivem expostos à pobreza. Tal condição está associada a variadas formas de violência, à exploração no trabalho, à exploração sexual, ao abuso de drogas, às doenças sexualmente transmissíveis e à gravidez precoce.

Essas adversidades, contudo, não atingem os jovens de maneira igual e uniforme. Um conjunto de fatores individuais, contextuais e socioespaciais, como a origem étnicaracial, a disponibilidade de recursos comunitários e a região de moradia torna alguns meninos e meninas mais suscetíveis do que outros, a privações e discriminações (UNICEF, 2011). A taxa de letalidade nesta faixa etária é também muito alta, conforme demonstra o levantamento feito entre 2006 e 2012 por Borges e Cano (2014). Segundo eles, cerca de 33.000 adolescentes perderam a vida em razão de homicídio no país, o que configura uma situação alarmante do ponto de vista da saúde pública.

Soma-se a isso, o fato de vivermos em um mundo extremamente competitivo e em 
desequilíbrio, cujas oportunidades de trabalho, bem-estar e lazer são restritas (BarberMadden \& Saber, 2010). A desigualdade social se faz presente no cotidiano daqueles que não conseguem ter suas necessidades básicas atendidas e, tampouco, desfrutar de uma vida digna e segura. Portanto, tornar-se autônomo, independente e apto a lidar com problemas é um enorme desafio a ser conquistado por jovens de todos os segmentos, especialmente os que vivem em situação de exclusão (UNICEF, 2011). Conforme destaca Porto (2010, p. 90), "os excluídos dos direitos tornam-se alvos, ou atores, mais imediatos da violência" e ora são vistos como algozes, ora como vítimas.

Neste cenário, Barber-Madden e Saber (2010) apontam que as assimetrias sociais presentes na contemporaneidade têm repercutido no processo de socialização dos adolescentes, no modo como eles respondem às adversidades e na maneira como interagem. Longe de ser uma etapa pacífica do desenvolvimento, a adolescência não existe independente de um contexto definido, e necessita dele para ser compreendida (Fishman, 1996). Assim, ela é marcada por uma série de mudanças biopsicossociais que podem ser atenuadas ou agravadas em função de aspectos ambientais, culturais e históricos (Outeiral, 2003).

Os comportamentos transgressores, típicos dessa fase, costumam ser transitórios e estão associados a fatores de risco e de proteção (Dell'Aglio \& Nardi, 2010). Entretanto, alguns jovens são mais suscetíveis a apresentar conduta transgressora, a depender de características pessoais, contextuais e circunstanciais. Esse tipo de comportamento provoca prejuízos para o próprio autor das ações, para sua família e para a sociedade, sendo que muitos deles acabam respondendo na justiça pelas infrações (Penso, Conceição, Costa \& Carreteiro, 2012).

Tais condutas, denominadas de atos infracionais, equivalem à pratica de crime ou contravenção penal, sendo que o abuso ou ofensa sexual executada por um adolescente se 
insere nesta categoria, conforme rege o Estatuto da Criança e do Adolescente, ECA (Brasil, 1990). Assim, o abuso sexual, tanto do ponto de vista de quem sofre a violência (Brasil, 2013) como de quem o pratica, é considerado um problema complexo de saúde pública, que necessita de planejamento e de políticas de enfrentamento (Penso et al., 2012). O próximo tópico será discutido com ênfase neste último conteúdo.

\section{Políticas de Enfrentamento à Violência Sexual para Vítimas e Autores}

O Plano Nacional de Enfrentamento à Violência Sexual contra Crianças e Adolescentes se constitui na principal política brasileira de combate à violência sexual infanto-juvenil, cujo objetivo é assegurar a proteção integral a indivíduos entre zero e 18 anos de idade que estejam em situação ou risco de sofrer violência sexual. O referido plano, em vigor desde o ano 2000, tem seis eixos estratégicos, a saber: (a) conhecimento da realidade, diagnóstico da situação de enfrentamento e divulgação de dados; (b) mobilização e articulação nacional, regional e local para eliminar a violência sexual; (c) defesa e responsabilização; (d) atendimento em rede às crianças, adolescentes e suas famílias; (e) prevenção e (f) protagonismo infanto-juvenil (Brasil, 2001).

Para colocar em execução as metas estabelecidas nesses eixos, foi criado o Programa Sentinela, pautado em uma concepção intergovernamental, de caráter intersetorial (Paixão \& Deslandes, 2010). O Programa foi implementado através de serviços e centros de referência com capacidade técnica e recursos humanos para disponibilizar atendimento especializado à população de diferentes regiões do país (Brasil, 2001).

As medidas demonstram empenho por parte das instituições, órgãos governamentais e da sociedade civil na luta contra o fenômeno da violência sexual. Por outro lado, questionase a operacionalização em nível estadual e municipal das medidas preconizadas, uma vez

que diversos municípios brasileiros são destituídos de recursos logísticos, técnicos e 
materiais. Conforme apontam Paixão e Deslandes (2010), há um descompasso entre as metas estabelecidas e os indicadores analisados. Segundo as autoras, o Plano Nacional é extremamente abrangente e não revela a maneira como é posta em prática a atenção integral a crianças e adolescentes vítimas - que moram em localidades desprovidas de infraestrutura - bem como as "formas de ajuizar sobre o atendimento aos autores da violência sexual" (p.120).

Em avaliação semelhante, realizada no Programa Sentinela de Blumenau/SC, Espindola e Batista (2013) constatam a falta de intervenções para perpetradores de abuso ou ofensa sexual e a fragmentação de informações sobre eles. O levantamento feito com base em dados de 2009 indica, por exemplo, que a idade do autor da violência era desconhecida ou não constava nos prontuários em $36 \%$ dos casos notificados.

Em contrapartida, naqueles casos em que a idade do abusador foi identificada, se verificou que $28 \%$ das situações haviam sido provocadas por adultos entre 25 e 59 anos; 25\%, por adolescentes entre 12 e 17 anos; e 5\%, por pré-adolescentes de 10 e 11 anos. A faixa etária dos 18 aos 24 anos foi responsável somente por 3\% dos episódios, índice igual ao de idosos com mais de 60 anos de idade (Espindola \& Batista, 2013). Logo, no estudo citado, os adolescentes compõem o segundo grupo com maior taxa de agressão sexual, mas podem ultrapassar a taxa de adultos se for somado ao índice de $5 \%$ que corresponde às violações cometidas por indivíduos de 10 e 11 anos. Ou seja, a pré-adolescência e a adolescência mostram-se momentos cruciais para a elaboração de políticas preventivas da prática de abuso sexual e para a execução de intervenções aos jovens perpetradores (Oliver, 2007).

Para tanto, é importante aprimorar e integrar a forma de notificação de casos em todo o território nacional, conforme destaca o Plano Nacional de Enfrentamento à Violência Sexual contra Crianças e Adolescentes (Brasil, 2013). Essa é uma das conclusões 
mencionadas na nova versão do referido Plano, que sofreu um longo processo de revisão e reformulação nos últimos anos.

Destaca-se, também, a necessidade de construção de indicadores com o propósito de viabilizar o acompanhamento das ações de enfrentamento à violência sexual (Paixão \& Deslandes, 2010), alinhadas às diretrizes da Organização das Nações Unidas, ONU (Brasil, 2013). Tal lacuna foi detectada em 2007, porém, até o momento, “o Brasil não produziu dados nessa área para que se possa estabelecer uma linha de base para o processo de monitoramento e avaliação" (p. 22). Esse processo se constitui em um enorme desafio, pois a inexistência de uma cultura de avaliação, em nosso país, impede o reconhecimento das políticas públicas mais eficazes (Brasil, 2013; Paixão \& Deslandes).

Mesmo com as limitações diagnosticadas, no Plano Nacional são recomendadas ações para melhoria do conhecimento na área da violência sexual. Destaca-se, por exemplo, o mapeamento e a elaboração de um banco de dados capaz de subsidiar a implantação de políticas e a "disseminação de metodologias nacionais e internacionais bem-sucedidas na prevenção e no enfrentamento do abuso e/ou exploração sexual de crianças e adolescentes, bem como à pessoa que comete violência sexual" (Brasil, 2013, p.47).

A partir dessa conclusão, percebe-se que há espaço e interesse em investigações relativas aos autores de violência, especialmente jovens e adolescentes que cometem ofensa sexual. Conforme apontam Costa, Junqueira, Meneses e Stroher (2013), neste quesito, a literatura nacional é incipiente e os contextos de atendimento reduzidos, o que torna o Brasil um campo fértil a novos projetos.

A ofensa/abuso sexual, perpetrado/a por adolescentes contra crianças ou outros adolescentes, é um tema ainda pouco explorado na realidade brasileira, tanto do ponto de vista acadêmico e científico, como de saúde pública (Costa, Ribeiro, Junqueira, Meneses \& Stroher, 2011). Apesar de envolver indivíduos em processo de desenvolvimento e suas 
famílias, a literatura da área está circunscrita às adversidades enfrentadas pelas vítimas, em detrimento às circunstâncias e consequências relativas à autoria dos episódios (Bianchini \& De Antoni, 2012). No que se refere às estatísticas de violência sexual contra crianças e adolescentes, percebe-se um fenômeno semelhante. Os dados disponíveis dizem respeito aos que sofrem a agressão e raramente mencionam as características sociodemográficas dos acusados.

Importante ressaltar, também, que as estatísticas publicadas sobre violência sexual utilizam um "macroconceito que envolve duas expressões: abuso sexual e exploração sexual” (SDH/PR, 2013, p. 21). A união dos dois conceitos se deve à necessidade de reforçar que ambos constituem uma afronta aos direitos humanos, embora precisem de políticas públicas de enfrentamento diferentes. Neste sentido, o termo violência sexual é definido como "todo ato, de qualquer natureza, atentatório ao direito humano, ao desenvolvimento sexual da criança e do adolescente, praticado por agente em situação de poder e de desenvolvimento sexual desigual em relação à criança e adolescente vítimas” (p.22).

O serviço nacional denominado Disque 100, por exemplo, criado pela Secretaria de Direitos Humanos da Presidência da República (SDH/PR, 2015) para receber denúncias de violações, aponta que entre janeiro e março de 2015 foram denunciadas 4.480 situações de violência sexual contra a população infanto-juvenil, sendo que $85 \%$ destas são relativas a situações de abuso sexual. Mesmo assim, não são disponibilizadas informações sobre o perfil dos suspeitos, como sexo, idade ou grau de parentesco.

Por outro lado, o levantamento realizado com base em dados consolidados de 2009 pelo CEREVS (Centro de Referência em Violência Sexual), pertencente à Vara da Infância e da Juventude do Distrito Federal (VIJ/DF, 2010), apresenta informações consistentes sobre os perpetradores. Dentre as informações, destaca-se a idade destes indivíduos. Segundo a pesquisa, jovens entre 12 e 17 anos foram responsáveis por 13,58\% dos casos de violência 
sexual no DF, percentual igual ao de adultos entre 40 e 44 anos de idade. O levantamento revela, também, que adultos entre 35 e 39 anos ocupam o terceiro lugar, com 11, 73\%, enquanto em uma parcela significativa de casos (18\%) não há referência à idade do autor. 


\section{JUSTIFICATIVA E OBJETIVOS}

Os números anteriormente apresentados nos permitem pensar que, para a construção de estratégias de enfrentamento à violência sexual e de programas interventivos, é imprescindível conhecer, em primeiro lugar, as características do público alvo. A elaboração de um plano de atendimento dirigido a agressores sexuais deve levar em consideração sua faixa etária e estágio de desenvolvimento, sob o risco de gerar mais prejuízos do que benefícios ao misturar pessoas de diferentes idades em um mesmo contexto (Barroso, 2012; Ryan, 2012; Worling \& Langton, 2012). Portanto, identificar o perfil dos autores é importante para promover uma reabilitação eficaz e prevenir novos casos (Penso et al., 2012).

Sensível a essa demanda, o SINAN - Sistema de Informação de Agravos de Notificação - que tem por objetivo registrar dados sobre agravos em todo o território nacional (IBGE, 2015), efetivou atualizações no modo de registro de casos de violência sexual. As mudanças dizem respeito à ficha de notificação utilizada para coleta de dados, que foi ampliada não somente para detalhar o tipo de agressão sofrida pela vítima, como também para colher informações acerca do provável protagonista da violência. O item 64, por exemplo, referente a quem praticou o ato violento, se destina a identificar a idade do acusado, conforme mostra o modelo de ficha do SINAN. O primeiro modelo (Anexo 1), que foi usado desde 2009 até o ano de 2014, não mencionava dados a esse respeito; o segundo modelo (Anexo 2), foi construído para substituir o modelo anterior, em contrapartida, busca captar informações sobre o provável autor e sua idade. Ressalta-se, contudo, que em alguns serviços de saúde ainda não houve substituição das fichas de notificação.

Parte-se do pressuposto que, para combater situações de ofensa/abuso sexual contra crianças e adolescentes, é preciso ampliar o conhecimento e incentivar ações integradas em 
todo o país, tanto às vítimas como aos perpetradores. Sobre estes últimos, são ainda modestos os locais de atendimento para pessoas jovens envolvidas na prática de abuso sexual e escassos os resultados sobre os programas interventivos. O Distrito Federal é uma exceção, pelo fato de contar com um projeto dessa natureza desde 2009, cuja experiência subsidiou o presente estudo.

\section{Objetivo Geral}

Conhecer os aspectos individuais, familiares e contextuais de adolescentes em situação de ofensa sexual, atendidos em um centro de referência que dispõe de intervenção para autores de ofensas/abusos sexuais, com o intuito de prevenir a reincidência.

\section{Objetivos Específicos}

1. Descrever as características sociodemográficas individuais e familiares de quatro adolescentes, bem como a dinâmica ofensa/abuso sexual;

2. Inserir instrumento (ERASOR) no contexto interventivo, para estimar as chances de reincidência do comportamento sexual ofensivo;

3. Identificar os fatores de risco para a reincidência do ato sexual ofensivo;

4. Conhecer a perspectiva de futuro dos adolescentes por meio de um recurso gráfico. 


\section{FUNDAMENTOS TEÓRICO-EPISTEMOLÓGICOS}

\section{O Pensamento Sistêmico}

Por tratar-se de um de objeto de estudo que engloba uma multiplicidade de fatores históricos, sociais, culturais e psicológicos, adotou-se o pensamento sistêmico para embasar teoricamente este trabalho. $\mathrm{O}$ referencial diz respeito a uma mudança de paradigma, iniciada a partir da segunda metade do século XX, que é utilizado na contemporaneidade como pano de fundo para a compreensão de vários fenômenos. Denominada de ciência pós-moderna ou ciência novo-paradigmática, se distingue da ciência tradicional em três dimensões principais: a complexidade, a instabilidade e a intersubjetividade (Esteves de Vasconcellos, 2012).

Quanto à primeira dimensão, Japiassú e Marcondes (2006, p. 49) explicam que a complexidade procura "(a) integrar no conhecimento do real a desordem, o incerto, o inesperado e o acaso e (b) superar as clivagens entre modelos rivais: sujeito/objeto, indivíduo/sociedade, natureza/cultura, ordem/desordem, explicação/compreensão". Trata-se de uma inovadora forma de entender os fenômenos, na qual as contradições são pertinentes e não precisam ser refutadas ou excluídas.

Ao contrário do paradigma da simplificação, usado na ciência tradicional, pensar complexamente é sinônimo de contextualização, cujo objeto ou problema têm seu foco ampliado e os sistemas tornam-se igualmente amplos. Neste sentido, o contexto diz respeito a todas as relações entre os elementos envolvidos e extrapola a noção de ambiente. Por fim, Esteves de Vasconcellos (2012, p. 114) salienta que "pensar o objeto em contexto significa pensar em sistemas complexos, cujas múltiplas interações e retroações não se inscrevem numa causalidade linear (...)", mas ocorrem de maneira circular.

A segunda dimensão ou pressuposto epistemológico é o da instabilidade, cuja ideia central é a de um mundo em transformação. Os seres, segundo Morin (2008), se encontram 
em movimento, em constante processo de autorregulação e desorganização, organização e reorganização. Esse pressuposto compreende as incertezas, as assimetrias e os paradoxos existentes nos fenômenos, ao abandonar a convicção na regularidade da repetição dos mesmos. Assim, a crença no controle e na estabilidade que ora determinava o entendimento do mundo é deixada de lado, e passa-se a admitir a imprevisibilidade de muitos eventos (Esteves de Vasconcellos, 2012).

A última dimensão se refere à intersubjetividade, que admite não ser possível um conhecimento objetivo do mundo, pois, a objetividade nada mais é que uma tentativa de constituir uma "ciência que se afaste da sensibilidade e da subjetividade, baseando suas conclusões em observações controladas, em verificações, medidas e experimentos, cuja validade seja garantida pela possibilidade de reproduzi-los e testá-los" (Japiassú \& Marcondes, 2006, p. 205). O pressuposto da intersubjetividade, por sua vez, reconhece uma multiplicidade de verdades a respeito de um determinado fenômeno, sendo que o conhecimento deste emerge da relação entre o pesquisador e o objeto. Assim, a realidade não está desconectada do observador, sendo o conhecimento científico uma construção social (Esteves de Vasconcellos, 2012).

Diante desses pressupostos, a noção de família é incluída em virtude de sua relevância para a compreensão do tema em estudo. Ela pode ser entendida como um sistema, ou seja, "vista em seu contexto (um sistema em relação com outros sistemas); em sua complexidade (com interações múltiplas e diversas); em sua instabilidade (articulações e mudanças em constante andamento) e em sua intersubjetividade (realidades múltiplas decorrentes de interações) " (Costa, 2010, p. 97).

Sob o enfoque da teoria sistêmica, família é:

"Um sistema social aberto em transformação, mantendo laços com o extra-familiar, possuindo uma capacidade de desenvolvimento e tendo 
uma estrutura organizacional composta por subsistemas. O indivíduo, que é ele próprio um subsistema da família, enfrenta diferentes tarefas e adquire diferentes habilidades interpessoais, nos diversos subsistemas" (Minuchin, 1982, p. 231).

A família, portanto, pode ser concebida como um contexto "em desenvolvimento", fundamental para a evolução da espécie humana por possuir propriedades e limitações diferentes de todos os outros sistemas (Carter \& McGoldrick, 1995). Seus subsistemas são separados por fronteiras rígidas ou flexíveis e constituídos por regras próprias que regulam as trocas e os intercâmbios estabelecidos entre eles, permitindo a manutenção de sua integridade e de seus padrões próprios. A falta ou o afrouxamento exacerbado dessas fronteiras e limites, por exemplo, caracteriza a disfuncionalidade em um sistema familiar (Minuchin, 1985).

Quando o grupo familiar tem dificuldade em se organizar, eleger prioridades e definir papéis, as formas de interação tendem a se cristalizar resultando em afastamento ou, ao contrário, se transformando em excessiva interferência por parte de um membro na vida de outro. Nesta situação, podem ocorrer alianças entre determinados indivíduos do grupo, do mesmo modo que comportamentos periféricos (Gomes, 1986). É comum o surgimento de problemas na comunicação, como falta de diálogo e duplas mensagens. Há risco de haver inversão de papéis por parte de pais e filhos, além da falta de planejamento e organização para atingir metas e objetivos. As negociações e adaptações às mudanças são também prejudicadas nestas famílias, enquanto a rigidez é uma característica que as acompanha (Weitzman, 1985).

No que diz respeito à prática de ato infracional, a exemplo da ofensa sexual cometida por adolescente, observa-se uma estreita relação entre comportamento transgressor e família com funcionamento disfuncional (Penso et al., 2012). Neste contexto, o ato pode ser 
interpretado como um sintoma, se tomarmos por base a concepção sistêmica. De acordo com Gomes (1986, p. 30), os sintomas têm "tanto uma função individual como social no grupo familiar e constituem-se numa denúncia de que algo vai mal nesse grupo”. O envolvimento em atos infracionais, por conseguinte, é um sinal que tem como função regular o sistema para suplantar a crise já instalada, sem, no entanto, efetivar de fato qualquer mudança (Fischman, 1996; Penso, Costa \& Sudbrack, 2008).

Assim sendo, toda interpretação para o fenômeno da ofensa sexual apresentada neste estudo tem como pano de fundo a perspectiva sistêmica. O adolescente autor de ofensa ou abuso sexual integra um sistema (família) que mantém contato com outros sistemas, e nesta conjuntura desempenha seus papéis. Situações de violência vividas pelo jovem, dentro e fora da família, conluios, rupturas e conflitos constituem parte de sua experiência, inserida em um contexto maior (Gomes, 1986).

A família é o meio social de origem do adolescente, sua primeira vivência de relações e sustento, dotada de recursos para realizar mudanças (Fischman, 1996). Por isso, a visão que se tem dele não pode ser apartada de seu contexto que inclui, invariavelmente, tanto adversidades como potencialidades. São estas últimas, as potencialidades, que necessitam ser ativadas para que ocorra uma efetiva transformação no funcionamento familiar, no sistema de crenças e, consequentemente, na trajetória do adolescente.

\section{Adolescência e Sexualidade: da Prática Normativa ao Ato Sexual Ofensivo}

De acordo com o Estatuto da Criança e do adolescente (ECA), o período da infância e a designação dada à categoria 'criança' diz respeito a indivíduos que têm entre zero e 12 anos incompletos, ao passo que adolescente é a pessoa na faixa dos 12 aos 18 anos de idade (Brasil, 1990; 2010). A adolescência é caracterizada por uma gama de transformações biológicas, sociais, psicológicas e emocionais que ocorrem neste período do 
desenvolvimento humano (Penso et al., 2012).

Por outro lado, não existe apenas uma adolescência ou um jeito específico de vivenciá-la, pois a heterogeneidade de realidades e ambientes a tornam uma experiência complexa, única e multidimensional. Assim, as mudanças que acontecem neste período se dão de forma contextual e os valores da cultura, do grupo e da família a qual pertence o adolescente interferem na incorporação de novos papéis e limites, nas manifestações de afeto, de intimidade e, sobretudo, no comportamento sexual (Penso et al., 2012).

A adolescência é também uma fase em que a pessoa experimenta o processo de individuação, adquire habilidades e expande seu repertório relacional, tornando delicado o estabelecimento de parâmetros de conduta como os que dizem respeito ao exercício sexual normativo (Barroso, 2012). Todas essas transformações têm início antes mesmo da adolescência, uma vez que o começo da puberdade é crucial para a sexualidade e marcado pelo aumento de fantasias e atividades sexuais exploratórias (Oliver, 2007).

A sexualidade, por sua vez, diz respeito a uma gama manifestações, podendo ser interpretada como "um processo simbólico e histórico, que expressa a constituição da identidade do sujeito, como ele vive a questão da intimidade (público versus privado), da significação das normas, da moral e da ética grupal" (Kahhale, 2001, p. 179). Na puberdade, a gradativa experimentação de comportamentos sexuais conduz à descoberta do que é socialmente tolerado. À medida que a pessoa cresce, tais comportamentos se tornam mais reservados e menos perceptíveis aos adultos em virtude da assimilação das regras e da distinção entre uma conduta aceita e uma conduta censurada (Murrie, 2012; Oliver, 2007). Logo depois, quando o indivíduo atinge a adolescência, uma parcela significativa dos jovens começa a ter contatos sexuais entre si (Murrie), cuja iniciação sexual se realiza sob a influência de modelos de comportamento, de permissividade e de concepções acerca do que é ser menino ou menina (Borges \& Nakamura, 2009). 
Crenças sobre masculinidade e feminilidade, frutos de uma determinada cultura, ajudam a balizar as atitudes e as posturas adotadas pelos adolescentes. Pensamentos a respeito de cada um desses universos constituem valores que, segundo Minayo (2005), podem perdurar ao longo de gerações e reforçar estereótipos sobre gênero. A autora enfatiza que do ponto de vista do patriarcado, o homem foi historicamente colocado no lugar da ação, das decisões, de sujeito da sexualidade e em oposição à condição de objeto designada à mulher, "investido significativamente com a posição social (naturalizada) de agente do poder da violência (...)" (p. 24).

O estudo de Borges e Nakamura (2009) sobre iniciação sexual de jovens entre 14 e 18 anos de idade, por exemplo, aponta diferentes interpretações para o exercício da sexualidade, a depender do sexo do adolescente. Participantes de quatro grupos focais realizados no contexto da pesquisa demonstraram estar fortemente atrelados às normas sociais e aos papéis de gênero, sem perceberem as desigualdades e assimetrias criadas por essas representações. A ideia de que sexo é um instinto físico e incontrolável está presente no discurso dos garotos, enquanto o binômio amor-sexo prepondera na fala das meninas. Segundo Borges e Nakamura, tais percepções são precocemente construídas, reproduzidas e norteiam as noções do grupo de pares no âmbito da iniciação sexual.

Uma outra vertente de investigação se refere ao diagnóstico de problemas de conduta sexual expressos ainda na infância. O relatório do grupo de trabalho americano sobre crianças com esse tipo de situação, denominado Task Force on Children with Sexual Behavior Problems (Association for the Treatment of Sexual Abusers [ATSA], 2006), aponta que para determinar se uma atitude é inapropriada deve-se considerar se esta é compatível ao período de desenvolvimento da criança, à cultura onde ela está inserida e ao tempo dedicado pela criança ao assunto. Além disso, é preciso avaliar se o comportamento implica um dano potencial, ou seja, se as idades entre as crianças envolvidas nos atos são 
discrepantes, se há presença de força ou coerção e indícios de lesões físicas, bem como de reações estressantes associadas aos comportamentos.

Especificamente sobre as questões contextuais, Murrie (2012) salienta que as avaliações pertinentes aos comportamentos sexuais problemáticos estão sujeitas a erro, quando há uma rigidez excessiva no momento de elencar o que é compatível ou não a determinada cultura. Em contrapartida, Murrie enfatiza que relativizar ou responsabilizar o ambiente de forma inadequada pode ser igualmente equivocado.

Por fim, é importante ressaltar que a metodologia utilizada nas pesquisas a esse respeito é, por vezes, limitada e sujeita a apresentar dados enviesados, conforme aponta Barroso (2012). O autor revela que alguns investigadores se baseiam na análise retrospectiva de informações provenientes de autorrelatos dirigidos a adolescentes, enquanto outros usam instrumentos dirigidos aos pais sobre o comportamento dos seus filhos, o que pode comprometer os resultados dos estudos. Trata-se, desta maneira, de um tema propenso a diversos estilos de investigação e interpretações. Ademais, as atitudes sexuais inapropriadas ocorrem em um continuum (Ryan, 2012) exigindo uma avaliação global que extrapola a mera constatação de sua presença ou ausência (Murrie, 2012).

Para minimizar possíveis controvérsias, Barroso (2012) reforça que é preciso discriminar as atitudes que fazem parte do desenvolvimento saudável daquelas entendidas como nocivas, dentre as quais está o comportamento sexual ofensivo, aqui denominado ofensa sexual ou abuso sexual, conceitos explorados no próximo tópico.

\section{Ofensa Sexual/Abuso sexual}

Ofensa sexual é uma expressão empregada por autores estrangeiros (Ryan 2012; Worling \& Langton, 2012) que equivale, no contexto nacional, ao abuso sexual (Hatzenberger, Habigzang \& Koller, 2012). Contudo, o termo ofensa sexual se refere à 
pessoa que praticou o ato, enquanto abuso sexual é empregado às vítimas. É um assunto relevante sob o ponto de vista da saúde pública e tem ganho destaque nas últimas décadas, sobretudo os casos cuja autoria é atribuída a adolescentes. Instituições internacionais, do porte da Organização Mundial da Saúde (OMS) e da União Europeia (EU) reconhecem a importância de investimentos na área, bem como de ações preventivas, e incentivam a prospecção de novos trabalhos (Barroso, 2012).

O fenômeno começou a ser abordado com afinco no contexto canadense e norteamericano a partir da década de 1990, com estudos cuja finalidade era explorar as características dos autores e os aspectos legais das agressões (Barbaree \& Marshall, 2006). Desde então, os estudos têm privilegiado a perspectiva da vítima e não do agressor, sobretudo quando este indivíduo está em estágio de desenvolvimento próximo ao daquele que é subjugado, como no caso de adolescentes que abusam sexualmente de crianças ou de jovens na mesma faixa etária (Bianchini \& De Antoni, 2012; Oliver, 2007; Worling \& Langström, 2003).

Embora a maioria das ofensas seja cometida por adultos (Vandiver, 2006; Worling \& Langton, 2012), estimativas internacionais apontam que cerca de $30 \%$ dos casos são protagonizados por pessoas menores de 18 anos de idade (Oliver, 2007). Esse número pode ultrapassar os $50 \%$ quando se referir a ofensas perpetradas exclusivamente contra crianças (Barbaree \& Marshall, 2006; Murphy \& Page, 2000; Ryan, 2012), o que explica as diferenças estatísticas sobre a ocorrência dos episódios.

Em outras palavras, os atos sexuais abusivos variam de acordo com as características da ofensa, com a idade da vítima, a história e a trajetória de vida do perpetrador da violência, as habilidades sociais e interpessoais deste indivíduo, a relação estabelecida com seus familiares e grupo de pares, a experiência e conhecimento sobre sexo, além de sua saúde mental (Ryan, 2012). A pesquisa realizada por Miner et al (2010), por exemplo, aponta 
diferenças entre aquele adolescente que abusa sexualmente de crianças, daquele que escolhe como vítimas pessoas de sua faixa etária ou adulta. Os resultados demonstram que o primeiro grupo apresenta sentimentos de inadequação e sexualidade exacerbada e, ao mesmo tempo, atitudes mais positivas no que diz respeito às relações interpessoais. O segundo grupo, composto por adolescentes que abusam de pares ou adultos, evidencia um maior número de comportamentos delinquentes e agressivos, menos competência social e baixa autoestima.

Investigação semelhante empreendida por Seto e Lalumière (2010), uma metaanálise que envolveu cerca de 3000 adolescentes agressores sexuais e 13393 agressores não sexuais, apontou que aqueles que haviam cometido ofensa sexual tinham pior histórico de vitimização sexual, de abuso físico e negligência do que os demais. Além disso, exposição precoce a sexo e pornografia, bem como interesses sexuais atípicos foram revelados com elevada frequência por este grupo. Os jovens que se engajam em situações dessa natureza constituem, portanto, uma categoria heterogênea em virtude da diversidade de variáveis associadas à prática (Butler \& Seto, 2002; Hunter, 2012a; Mines et. al. 2010) e se assemelham muito mais aos adolescentes que cometem outros tipos de atos abusivos, do que à população adulta envolvida em crimes sexuais (Ryan, 2012).

A ofensa/abuso sexual é definido como todo o ato sexual que empregue violência física e verbal, além de estratégias de manipulação e coerção contra as vítimas (American Psychiatric Association, 1999). A prática pode incluir diversas atitudes sexualizadas, com ou sem contato físico, que causam danos e prejuízos à vítima e cuja ocorrência se dá em ambiente intra ou extrafamiliar (Hatzenberger, Habigzang \& Koller, 2012).

Trata-se, resumidamente, de qualquer prática sexual que ocorra sem consentimento, sem igualdade e como resultado de uma coerção (ATSA, 2006; Barroso, 2012). Todavia, não constitui em si um diagnóstico, um transtorno ou uma condição, mas um comportamento produzido pelo indivíduo (Worling \& Langton, 2012) que diz respeito a complexas 
dinâmicas entre quem é submetido à violência e quem a protagoniza. Também não deve ser confundido com pedofilia, cujo protagonista das ofensas deve ter pelo menos 16 anos de idade e ter cinco anos a mais que sua vítima (Ryan, 2012).

Quando se refere, por exemplo, à ofensa praticada por um adulto contra uma criança, a simples diferença de idade é um indicativo do problema, ao contrário das interações que ocorrem entre indivíduos da mesma faixa etária. De acordo com Ryan (2012), o consentimento é um dos principais aspectos a serem considerados nos episódios ofensivos. Para a autora, a pessoa precisa ter, entre outros atributos, plena capacidade para entender o que lhe é proposto, competência para decidir, consciência de potenciais riscos e das consequências implicadas na decisão.

No que tange à compreensão do fenômeno sexual ofensivo praticado por jovens ou adolescentes, é preciso levar em conta o momento do desenvolvimento em que se encontra este indivíduo em termos cognitivos, emocionais e comportamentais. As mudanças pelas quais passam os adolescentes têm impacto em todos os aspectos da sua sexualidade e na forma como processam as informações (Worling, 2012). Ao contrário do que se possa presumir, a maioria daqueles que cometem ofensas na adolescência não voltam a repeti-la (Ryan, 2012; Vandiver, 2006; Worling \& Langström, 2003), muito embora seja comum o adulto ofensor sexual ter iniciado sua carreira de abusos na juventude (Oliver, 2007). A experiência pode estar mais relacionada à imaturidade cognitiva e ao próprio processo de amadurecimento do que a um padrão de comportamento específico (Worling).

Trabalhos que têm abordado as origens do comportamento sexual ofensor apontam que o primeiro episódio costuma ocorrer na adolescência (Marshall \& Marshall, 2000; Smith, Wampler, Jones \& Reifman, 2005; Worley, Church \& Clemmons, 2012) e que a partir dele o problema ganha visibilidade. Por esta razão, conhecer as características da família, do contexto e as adversidades que compõem a trajetória de cada adolescente é um 
importante passo para compreender seu comportamento e suas escolhas, como veremos no próximo tópico.

\section{A Família do Adolescente que Comete Ofensa Sexual: \\ Contexto e Adversidades}

Pensar a família do adolescente que pratica um ato infracional, seja ele de que natureza for, é uma forma de entender o seu universo e a rede de relações que o circunda (Penso et al., 2012), uma vez que a família é o primeiro contexto de desenvolvimento do indivíduo. Segundo Dessen e Polônia (2007), os acontecimentos e as experiências vividas na família favorecem a estruturação de repertórios comportamentais, de padrões de conduta para a resolução de problemas que interferem nas formas de subjetivação e de interação social.

Assim, o casal parental tem um papel relevante na manutenção, na formação e na transferência de significados e crenças aos filhos. A pesquisa empreendida por LeVine (1988) com pessoas de diferentes culturas aponta, por exemplo, três objetivos a serem atingidos pelos pais ou cuidadores. O primeiro deles é garantir a sobrevivência física dos seus descendentes; o segundo, transmitir habilidades que os tornem autônomos; e o terceiro, se centra na difusão de valores culturais. $\mathrm{O}$ autor destaca que para conquistar essas metas é preciso que as famílias estabeleçam rotinas e atividades diárias que, por sua vez, variam de acordo com o estilo de organização dos genitores, das circunstâncias econômicas, laborais, sociais e do local onde vivem.

A variabilidade de situações das famílias interfere na forma como cumprem tarefas básicas do dia a dia, como a de cuidar de sua prole e protegê-la (Dessen \& Polônia, 2007). Significa dizer que, para muitos, a família pode não ser um reduto de segurança e bem-estar, mas constituir um ambiente conturbado, instável e de vínculos frágeis (Penso et al., 2012). 
Dentre os fatores que colaboram para o estabelecimento deste tipo de ligação, está a pobreza.

Tal adversidade é considerada um dos principais obstáculos a ser enfrentado pelas famílias, sobretudo as que vivem em contextos desprovidos de infraestrutura e recursos básicos. A pobreza influi diretamente na produtividade, restringe o acesso ao lazer, ao emprego, à moradia (De Antoni, Barone \& Koller, 2006) e limita, segundo Grisante e Aiello (2012), o "bem estar emocional, por aumentar os níveis de estresse e por provocar baixa autoestima; e, ainda, na interação familiar por gerar conflitos maritais sobre dinheiro, aumentar a responsabilidade de irmãos e por poder resultar em paternidade inconsistente e irresponsável” (p.196).

A pobreza, portanto, interfere na forma de criação dos filhos, contribuindo para que os pais se tornem menos disponíveis a manter interações positivas com suas crianças e adolescentes e propensos a utilizar a punição física (Cole \& Cole, 2004). Uma relação autoritária e controladora pode ser construída com o intuito de assegurar a subsistência da prole. Neste caso, a obediência costuma ser um atributo desejável e muitas mães desestimulam a curiosidade de seus dependentes ao exigir uma postura submissa para evitar que a proatividade os coloque em situações arriscadas, além das que enfrentam rotineiramente, conforme descrito no trabalho de McLoyd (1998).

Apesar deste modelo de prática disciplinar não ser utilizado exclusivamente pela população de baixa renda, observa-se que nestas famílias os meios de lidar com diferentes tipos de estresse são reduzidos e maiores as chances de ocorrer comportamentos abusivos (Cole \& Cole, 2004) ou negligentes, tendo em vista estudos que enfatizam que a pobreza potencializa outros fatores de risco (Pasian, Faleiros, Bazon \& Lacharité, 2013). Por isso, quando há famílias em situação de pobreza, conjugada à violência intrafamiliar, é preciso buscar alternativas dentro e fora deste ambiente para reverter a situação (De Antoni et al. 2006). 
Tal panorama, salienta Penso et al. (2012), é comum na trajetória de adolescentes que cometem ofensa sexual. De acordo com uma investigação das autoras, a história familiar de quatro jovens envolvidos em atos sexuais ofensivos contra crianças, no contexto brasileiro, abrange situações de negligência física e emocional, inconsistência ou ausência da relação entre o genitor do sexo masculino e o jovem, percurso com rompimentos e poucos vínculos efetivos, e uma figura materna dominadora e exigente. Todas as famílias pesquisadas tinham baixo poder aquisitivo e não dispunham de apoio comunitário, como creches e escolas em tempo integral.

Em relação às mães dos adolescentes daquele estudo, se caracterizavam pela rigidez e os mantinha sob vigilância constante. Elas demonstravam pouca tolerância a mudanças, dificuldade em aceitar o desenvolvimento sexual do adolescente e tendiam a reprimir qualquer manifestação ou impulso neste sentido. Para Penso et al. (2012), o desejo dessas mulheres seria o de conservar seus filhos na condição de dependentes, como seus auxiliares nos afazeres domésticos, no cuidado para com as crianças menores e nas demais tarefas da casa. Ou seja, são famílias em que as progenitoras são sobrecarregas e acabam por também sobrecarregar os adolescentes.

O trabalho de Rodgers e McGuire (2012) sobre adolescência e sexualidade, por sua vez, aponta que o impacto negativo da pobreza na vida de jovens oriundos de comunidades carentes pode ser atenuado por relações positivas com seus cuidadores. Segundo os autores, adolescentes que percebem um clima familiar amoroso e propenso ao diálogo estão menos suscetíveis a envolverem-se em comportamentos sexuais de risco como gravidez precoce na adolescência, sexo sem preservativos, múltiplos parceiros e relações abusivas no namoro. Os resultados sugerem que intervenções para prevenir a violência interpessoal e melhorar a habilidade parental são muito importantes na redução atitudes sexuais de risco na adolescência e no desenvolvimento de comportamentos ofensivos. 
Outro aspecto que contribui para reduzir as situações de ofensa sexual é evitar a repetição de um modelo baseado na violência para resolução de conflitos. A pesquisa realizada por McCuish, Cale e Corrado (2015), com adolescentes que praticaram ofensa sexual e adolescentes que cometeram outros tipos de infrações, demonstra que existe associação entre agressão física no contexto familiar, vivência de abuso sexual e transmissão transgeracional deste padrão. Embora exista, nos dois grupos, histórico de maus tratos físicos e sexuais, as famílias dos adolescentes que cometeram ofensa sexual apresentaram uma taxa maior de vitimização sexual. Os autores destacam que quando o abuso sexual se repete através das gerações, há uma tendência em "normatizar" esse ciclo, o que colabora para a prática sexual ofensiva e aumenta desproteção das prováveis vítimas.

A seguir são apresentados três artigos sobre o tema da ofensa sexual, elaborados a partir da revisão de literatura para esta pesquisa, que serão submetidos à publicação. O título do primeiro é "Adolescentes que cometeram ofensa sexual: Análise documental em processos judiciais"; do segundo, "Adolescente considerado autor de ofensa sexual: Proteção, responsabilização e medidas socioeducativas; e do terceiro e último é "Ofensa sexual perpetrada por adolescentes: Percurso e intervenção no contexto português e no brasileiro". 
Adolescentes que cometeram ofensa sexual: Análise documental em processos judiciais

\title{
Adolescents who have committed sexual offense: Documentary analysis in legal proceedings
}

\section{Adolescentes que han cometido delito sexual: Análisis documental en los procedimientos judiciales}

\begin{abstract}
Resumo. Este é um estudo exploratório que busca descrever características de adolescentes autores de ofensa sexual, de suas vítimas e o contexto em que os episódios ocorreram. A coleta de dados foi realizada por meio da análise documental de 15 processos judiciais relativos à prática de ofensa sexual, perpetrada por adolescentes, em uma região do Brasil. A análise foi feita com base em um protocolo contendo oito categorias referentes aos episódios ofensivos. Os achados revelam que as ofensas ocorreram no contexto intrafamiliar, extrafamiliar e institucional. As vítimas eram, em sua maioria, do sexo feminino. As ofensas sexuais contra crianças foram praticadas por adolescentes conhecidos das vítimas, ao contrário dos abusos cometidos contra indivíduos com 18 anos de idade ou mais. O estudo revela a necessidade de novas investigações para apoiar ações preventivas e ampliar o conhecimento na área.

Palavras-chave: abuso sexual, adolescente, vitimização
\end{abstract}

\begin{abstract}
This is an exploratory study that seeks to describe characteristics of adolescents who committed sexual offense, their victims and the context in which the events occurred. Data collection was conducted through document analysis of 15 lawsuits relating to the practice of sexual offense committed by teenagers in a region of Brazil. The analysis was based on a protocol containing eight categories relating to offensive episodes. The findings reveal that the offenses occurred in intrafamily, extra-familial and institutional contexts. The victims were mostly female. Sexual assaults against children were committed by teenagers known to the victims, unlike those perpetrated against individuals who were 18 or older. The study reveals the need for further research to support preventive actions and expand knowledge in the area.
\end{abstract}

Keywords: sexual abuse, adolescent, victimization

Resumen. Este estudio busca describir las características de los adolescentes que han cometido delitos sexuales, sus víctimas y el contexto en que ocurrieron. La recopilación de datos se realizó mediante examen teórico de 15 demandas relacionadas con la práctica de delito sexual, cometido por adolescentes, en una región de Brasil. El análisis se basa en un protocolo que contiene ocho categorías relacionadas con episodios ofensivos. Los resultados revelan que los delitos fueron cometidos dentro de la familia, fuera de la familia y en el contexto institucional. La mayoría de las víctimas eran mujeres. Los ataques contra los niños fueron cometidos por adolescentes conocidos, a diferencia de los abusos a personas de 18 años o mayores. El estudio revela la necesidad de nuevas investigaciones para apoyar las 
acciones preventivas y aumentar el conocimiento sobre el tema.

Palabras-clave: abuso sexual, adolescente, victimización

\section{Introdução}

O abuso sexual cometido por adolescentes é um grave problema de saúde pública que tem despertado o interesse de pesquisadores de várias nacionalidades, nas últimas décadas (Barroso, 2012; Ryan, 2012; Worling \& Langton, 2012). Também denominado de ofensa sexual em países de língua inglesa (Ryan; McCuish, Cale \& Corrado, 2015), é definido como todo o ato sexual que empregue violência física e/ou verbal, além de estratégias de manipulação e coerção contra as vítimas (American Psychiatric Association, 1999). Tal prática pode incluir diversas atitudes sexualizadas, com ou sem contato físico, que causem danos e prejuízos à pessoa vitimada (Hatzenberger, Habigzang \& Koller, 2012) e cuja ocorrência se dá em ambiente intrafamiliar, extrafamiliar ou institucional.

Por tratar-se de um fenômeno que abrange interações entre indivíduos da mesma faixa etária ou entre um adolescente e uma criança, os episódios ofensivos podem ser menos nítidos do que aqueles que envolvem um adulto e um pré-púbere, por exemplo. Por esta razão, o consentimento é um dos principais aspectos a serem considerados nas interações, tendo em vista que a pessoa necessita ter plena capacidade para entender o que lhe é proposto, competência para decidir, consciência dos potenciais riscos e das consequências implicadas nesta decisão (Barroso, 2012; Ryan, 2012).

Assim, é relevante observar a natureza das ofensas, o contexto em que elas ocorrem, as circunstâncias envolvidas e, sobretudo, as características dos ofensores (Seto \& Laumière, 2010). Quanto a este último item, percebe-se um incremento no número de estudos que abordam os perpetradores, suas condutas e a fase de desenvolvimento em que se encontram, 
pois, até recentemente, o comportamento sexual abusivo era atribuído apenas a pessoas adultas (Barroso, 2012).

A literatura atual indica uma realidade diversa (Barbaree \& Marshall, 2006). A participação de jovens nesse tipo de crime é frequente, como pôde ser detectado em um estudo realizado nos Estados Unidos, onde uma pesquisa demonstra que quase metade dos incidentes de agressão sexual registrados no país foram executados por menores de 20 anos de idade (Lowenstein, 2006). No contexto brasileiro, ao inverso de outras nações, há uma escassez de estatísticas sobre as situações ofensivas praticadas por adolescentes (Costa, et al., 2011). De acordo com o Plano Nacional de Enfrentamento à Violência Sexual contra Crianças e Adolescentes (2013) é preciso ampliar, aprimorar e integrar a notificação de casos em todo o território nacional, já que os dados disponíveis se referem predominantemente às denúncias e ao tipo de violência cometida, sem mencionar o perfil dos autores.

O serviço nacional denominado Disque 100, criado pela Secretaria de Direitos Humanos da Presidência da República (SDH/PR, 2015) para receber denúncias de violações, aponta que entre janeiro e março de 2015 foram registrados 4.480 casos de violência sexual contra a população infanto-juvenil, sendo que $85 \%$ destes são relativos a abuso sexual. Mesmo assim, não são disponibilizadas informações sobre os suspeitos, como sexo, idade ou grau de parentesco.

Na tentativa de ampliar o conhecimento acerca dos jovens perpetradores de violência sexual, Bianchini e De Antoni (2012) efetivaram uma pesquisa documental com base em 36 casos de ofensa registrados na Delegacia para o Adolescente Infrator (DPAI) em uma capital do sul do país, no ano de 2006. As autoras descreveram o perfil das vítimas, dos adolescentes que cometeram as ofensas e as situações de abuso, com o objetivo de apresentar algumas dessas dimensões. O levantamento apontou que a maioria das vítimas era do sexo masculino, 
coincidindo com o sexo dos ofensores, sendo que a agressão ocorria, preferencialmente, na residência ou na escola que as vítimas frequentavam.

São adolescentes, portanto, que precocemente veem-se envolvidos com o Sistema de Justiça e têm de arcar com as adversidades e consequências dos seus atos. Essas consequências tanto podem ser objetivas - como o cumprimento de medida socioeducativa - quanto subjetivas, que dizem respeito a estereótipos relacionados a pessoas em conflito com a lei.

No que tange aos efeitos objetivos, o ECA (Estatuto da Criança e do Adolescente) formado por um conjunto de normas de ordenamento jurídico, preconiza que o indivíduo entre 12 e 18 anos de idade que comete ato infracional está sujeito a receber desde uma medida protetiva, destinada a preservar ou recompor os seus direitos violados, até uma medida socioeducativa. Segundo o ECA, as medidas socioeducativas são aplicadas ao adolescente que é considerado responsável pelo cometimento de um ato infracional, ou seja, uma ação equivalente a um crime ou contravenção penal (Brasil, 1990).

O referido Estatuto, amparado na Constituição Federal Brasileira de 1988, deu início à doutrina de proteção integral para as crianças e os adolescentes, elevando-os à condição de sujeitos demandantes e não mais objetos da intervenção do Estado. Segundo Machado (2003, p. 411), "na base da noção de proteção integral está a ideia de efetivação de todos os direitos fundamentais de crianças e adolescentes, centrada na concepção de que estes direitos fundamentais formam um todo unitário e interdependente, que deve ser igualmente assegurado (...)".

A partir destas mudanças, passa a ser reconhecida a condição peculiar de desenvolvimento em que tais indivíduos se encontram. Compreende-se que, durante o período infanto-juvenil, o jovem esteja em processo de formação o que exige um tratamento diferenciado ao que é fornecido a uma pessoa adulta em casos que envolvem a aplicação de 
medidas socioeducativas. Machado (2003) enfatiza, também, o princípio da excepcionalidade e o da brevidade quanto ao sistema de responsabilização do adolescente que comete um delito, evitando ao máximo sua institucionalização. De acordo com a autora, esses princípios são extremamente relevantes tanto para os intérpretes da lei, como juízes, promotores e advogados, como para os aplicadores da mesma. Assim, o ECA prevê a responsabilização do adolescente infrator pelos atos cometidos, sem desconsiderar suas fragilidades, vulnerabilidades e potencialidades, promovendo espaços de reinserção pessoal e social.

Por outro lado, as consequências subjetivas para os autores de ofensa sexual abarcam fatores menos tangíveis, como rótulos e discriminações. Embora a literatura estrangeira recomende que o termo sexual offender seja utilizado apenas para se referir ao adulto ou ao jovem que já tenha passado por julgamento e recebido uma condenação (Ryan, 2012), esse princípio não isenta o acusado de enfrentar diferentes formas de preconceito ao ser considerado réu, ou até mesmo suspeito, de agressão sexual (Harris, Walfield, Shields \& Letourneau, 2015).

Além disso, para evitar prognósticos sombrios, é preciso adotar pelo menos duas precauções. A primeira é não comparar o comportamento do adolescente ao do adulto ofensor, uma vez que há mais diferenças do que similaridades entre ambos (Ryan, 2012). Depois, é desejável utilizar uma abordagem processual do desenvolvimento para compreender a conduta do jovem, bem como sua sexualidade, cujas escolhas ainda não estão cristalizadas (Murrie, 2012; Ryan). De acordo com Carpentier, Leclerc e Proulx (2011), somente alguns indivíduos que se envolveram na juventude em eventos sexuais ofensivos persistirão na mesma trajetória, apesar disso não significar a ausência de comportamentos criminais na vida adulta. 
Os adolescentes que se engajam em situações desse tipo constituem uma categoria heterogênea em virtude da diversidade de posturas associadas à prática, da época de início dos abusos, da história da sexualidade, dos traços de personalidade e das formas de atuação (Hunter, 2012a; Kemper \& Kistner, 2007; Kjellgren, Wassberg, Carlberg, Langström \& Svedin, 2006). Segundo Hunter (2012a), há subgrupos com características comuns, como aqueles que buscam exclusivamente vítimas na fase da infância e os que procuram pessoas de sua própria faixa etária ou adultas.

As razões para tais preferências residem em diversos aspectos e antecedentes dos jovens autores de ofensas sexuais e costumam ajudar na definição do tratamento mais adequado e na prevenção de recidivas (Hunter, 2012a; Kemper \& Kistner, 2007). Para Hunter, Hazelwood e Slescinger (2000) aqueles que cometem agressão contra seus pares ou contra adultos são mais suscetíveis a apresentar comportamentos violentos e envolvimento em outros tipos de delitos.

O estudo empreendido por Meng Chu e Thomas (2010) investigou as características, a versatilidade criminal e as taxas de reincidência de uma amostra de 156 adolescentes que cometeram ofensas sexuais e foram avaliados no contexto forense de Singapura, entre os anos de 1996 a 2007. Os adolescentes foram divididos em dois grupos. O primeiro, denominado de especialistas, reuniu apenas ofensores sexuais e o segundo, chamado de generalistas, era composto por adolescentes que haviam cometido diferentes tipos de crimes, além da ofensa sexual. Os resultados apontaram que houve reincidência em ambos; porém, no grupo dos generalistas verificou-se que 1 em cada 5 adolescentes cometeram crimes com uso exacerbado de violência em um período de dois anos e meio, diferentemente do grupo dos especialistas. Outra distinção disse respeito à escolha das vítimas: os generalistas escolheram pessoas fora do seu círculo familiar para a prática das ofensas sexuais, ao contrário dos especialistas. 
A meta-análise realizada por Seto e Lalumière (2010), por sua vez, aponta diferenças entre adolescentes que têm como alvo pessoas de sua faixa etária ou adultas e adolescentes que escolhem vítimas crianças. Os primeiros, apresentam histórico de prisões anteriores e vários fatores de risco associados a atos delinquentes, diferentemente do segundo grupo. Com base nessa constatação, Worling e Langton (2012) recomendam a construção de intervenções específicas para cada categoria de adolescentes. Conforme os autores, o tratamento deve ser personalizado com o intuito de evitar prejuízos àqueles que demonstram conduta menos comprometida.

Dessa forma, as implicações e consequências dos atos abusivos se estendem à prática clínica, à política instaurada nos serviços de atendimento, ao modo de organização das sociedades, além da instância judicial (Meng Chu \& Thomas, 2010). Com o objetivo de conhecer algumas características de adolescentes autores de ofensa sexual, o presente texto diz respeito a uma análise documental efetuada em processos disponibilizados pela Vara da Infância e da Juventude (VIJ) de uma cidade brasileira. Tal análise se refere a processos instaurados contra adolescentes do sexo masculino que foram denunciados por prática de ofensa sexual entre o início de 2008 e abril de 2013. O estudo descritivo tem como objetivo investigar as características desses adolescentes, de suas vítimas, colher informações sobre o ambiente em que os abusos foram cometidos e o tipo de vínculo existente entre os perpetradores das agressões e as pessoas abusadas. Em seguida é apresentada uma discussão a respeito dos procedimentos efetuados, das medidas preventivas e das políticas dirigidas aos adolescentes.

\section{Método}

\section{Procedimentos para a coleta de dados}

Primeiramente foi solicitada autorização para a realização da pesquisa junto à Vara 
da Infância e da Juventude (VIJ), órgão vinculado ao Tribunal de Justiça do Distrito Federal, localizado na região centro-oeste do Brasil. Após deferimento do termo, em 1/4/2013, foi feito contato com a seção encarregada pelas medidas socioeducativas da referida Vara. Por intermédio dos funcionários desta, solicitou-se junto ao cartório da instituição providências quanto aos processos. Em seguida, a repartição disponibilizou dois relatórios com dados estatísticos: um deles com os processos que estavam em tramitação, e outro com a lista geral dos documentos que foram registrados desde janeiro de 2008 até abril de 2013.

Para fins da pesquisa, foi separada uma amostra de 15 processos no total, sendo três de cada ano. Esse número foi definido pelo funcionário responsável pela seção da VIJ. Em razão do intenso fluxo de trabalho, das demandas na repartição e do curto período de tempo para atendimento à população, somente 15 processos foram disponibilizados. Portanto, essa escolha não foi feita pela pesquisadora. Os processos foram selecionados de forma aleatória, cujo critério norteador foi o período (janeiro de 2008 - abril de 2013) e o ato infracional cometido pelo adolescente. Trata-se, assim, de um recorte feito no conjunto de processos em que o próprio funcionário da repartição definiu o material fornecido à pesquisadora. Esta última não teve participação alguma na seleção dos processos que lhe foram entregues.

A pesquisa documental, para Gil (1999), é aquela que utiliza materiais que ainda não receberam qualquer tipo de análise e podem ser explorados e reelaborados de acordo com a finalidade da investigação. Há diversas fontes de pesquisa que podem servir a tal fim; entre elas estão os documentos oficiais, cartas, filmes, gravações e fotografias. Além disso, é consenso que esse tipo de material requer um cuidado especial por parte do pesquisador. Os cuidados éticos devem ser redobrados para preservar a identidade dos sujeitos, como por exemplo, os dados oriundos da esfera judicial e criminal (Berg, 2007). Assim sendo, o nome dos adolescentes e o número dos processos que fizeram parte da amostra foram preservados a fim de evitar possíveis riscos de identificação. 
O exame do material e as anotações ocorreram nas dependências da VIJ, em recinto designado pelos servidores do local, sendo concluído em dois dias consecutivos no mês de maio de 2013. O projeto de pesquisa foi antecipadamente submetido ao Comitê de Ética responsável pelas pesquisas realizadas na instituição. Tal estudo compõe um conjunto de investigações sobre o tema adolescência e ofensa sexual no Programa de Pós-Graduação em Psicologia Clínica e Cultura da Universidade de Brasília (UnB).

\section{Instrumento}

As informações foram registradas de forma manual com base em um protocolo construído antecipadamente. Para a construção do protocolo, foram escolhidas oito categorias baseadas na literatura e nas informações disponíveis nos processos. As categorias dirigiram-se, primeiramente, aos adolescentes que cometeram as ofensas, conforme segue: identificação do adolescente, idade do adolescente, abuso cometido individualmente ou em associação com outros jovens (individual ou coletivo) e número de vítimas. Em seguida, os itens se destinaram a coletar informações sobre as vítimas dos episódios: idade, sexo e relação com o agressor (conhecido ou desconhecido). Por fim, buscou-se coletar dados a respeito do contexto onde o abuso foi praticado (intrafamiliar, extrafamiliar ou em instituição de acolhimento/abrigo). Este último contexto - instituição de acolhimento - foi incluído pelo fato de ser um ambiente no qual ocorrem casos de abuso, apesar da subnotificação e da carência de estudos empíricos sobre o tema. Assim, trata-se de um ambiente com especificidades quanto à forma de ingresso e à permanência na instituição, diferentes dos contextos intra e extrafamiliar. A seguir estão elencadas as categorias que compõem a tabela1 apresentada nos resultados: 


\section{Tabela 1}

Categorias definidas para a pesquisa nos processos

\begin{tabular}{cccccccc}
\hline Adolescente & $\begin{array}{c}\text { Idade do } \\
\text { adolescente }\end{array}$ & $\begin{array}{c}\text { Prática do } \\
\text { ato }\end{array}$ & $\begin{array}{c}\text { Número } \\
\text { de }\end{array}$ & $\begin{array}{c}\text { Idade } \\
\text { da }\end{array}$ & $\begin{array}{c}\text { Sexo } \\
\text { da }\end{array}$ & Relação com & Contexto do \\
& & & vítima & vítima & abuso \\
& & & & & & & \\
\hline
\end{tabular}

\section{Análise dos Dados}

Por tratar-se de uma amostra reduzida, os dados foram categorizados e suas médias registradas. Com base nesses achados, foram interpretados de forma qualitativa, à luz da literatura utilizada para compor o estudo.

\section{Resultados}

Os resultados estão organizados em duas seções. A primeira delas mostra o número de processos presentes na VIJ entre janeiro de 2008 e abril de 2013 relativos ao ato infracional investigado no presente estudo. Tais informações fazem parte do Acervo de Processos, isto é, conjunto de documentos. A segunda seção apresenta a caracterização do adolescente que cometeu a ofensa sexual relacionando-o ao perfil e características da vítima e ao tipo de abuso cometido.

\section{Acervo de processos}

Mediante acesso ao relatório de processos disponibilizados pela VIJ, foi possível realizar o levantamento, cujos dados indicam que entre 1/1/2008 e 5/4/2013 foram contabilizados 192 processos relativos a atos infracionais pertencentes à categoria ofensa sexual. Todos os autos estavam sob segredo de Justiça, de acordo com as diretrizes estabelecidas nos artigos 143 e 144 do ECA (Brasil, 1990). Os processos estão divididos por ano, conforme segue: 


\section{Tabela 2}

Levantamento do número de processos entre 2008 e 2013

\begin{tabular}{ccccccc}
\hline Ano & 2008 & 2009 & 2010 & 2011 & 2012 & 2013 \\
\hline Processos/ano & 12 & 17 & 29 & 72 & 31 & 31 \\
\hline
\end{tabular}

Caracterização do adolescente e de suas vítimas

Com a finalidade de descrever o perfil dos adolescentes e de suas vítimas, os dados foram organizados na Tabela que seguir. As oito categorias resultantes do estudo estão agrupadas e divididas por subtítulos com o objetivo de descrever o conteúdo da pesquisa.

\section{Tabela 3}

Características dos adolescentes, das vítimas e do contexto

\begin{tabular}{cccccccc}
\hline Adolescente & $\begin{array}{c}\text { Idade do } \\
\text { adolescente }\end{array}$ & $\begin{array}{c}\text { Prática do } \\
\text { ato }\end{array}$ & $\begin{array}{c}\text { Número } \\
\text { de } \\
\text { vítimas }\end{array}$ & $\begin{array}{c}\text { Idade } \\
\text { da } \\
\text { vítima }\end{array}$ & $\begin{array}{c}\text { Sexo } \\
\text { da }\end{array}$ & $\begin{array}{c}\text { Relação com } \\
\text { vátítima }\end{array}$ & $\begin{array}{c}\text { Contexto do } \\
\text { abuso }\end{array}$ \\
\hline 1 & 17 & Coletiva & 1 & 14 & $\mathrm{~F}$ & Conhecida & Extrafamiliar \\
2 & 17 & Individual & 3 & $\begin{array}{c}11,12, \\
\text { Nano }\end{array}$ & F & Extrafamiliar \\
3 & 17 & Individual & 1 & 13 & $\mathrm{~F}$ & Conhecida & Extrafamiliar \\
4 & 16 & Individual & 1 & 4 & $\mathrm{~F}$ & Conhecida & Intrafamiliar \\
5 & 16 & Individual & 1 & 19 & $\mathrm{~F}$ & Desconhecida & Extrafamiliar \\
6 & 15 & Individual & 1 & 9 & $\mathrm{~F}$ & Conhecida & Intrafamiliar \\
7 & 15 & Coletiva & 1 & 18 & $\mathrm{~F}$ & Desconhecida & Extrafamiliar \\
8 & 15 & Individual & 3 & $4,4,3$ & $\mathrm{~F}$ & Conhecida & Institucional \\
9 & 14 & Individual & 1 & 9 & $\mathrm{~F}$ & Conhecida & Institucional \\
10 & 15 & Individual & 1 & 20 & $\mathrm{~F}$ & Desconhecida & Extrafamiliar \\
11 & 13 & Coletiva & 1 & 11 & $\mathrm{M}$ & Conhecida & Extrafamiliar \\
12 & 16 & Individual & 1 & 7 & $\mathrm{~F}$ & Conhecida & Intrafamiliar \\
13 & 14 & Individual & 1 & 8 & $\mathrm{M}$ & Conhecida & Intrafamiliar \\
14 & 12 & Individual & 1 & 8 & $\mathrm{~F}$ & Conhecida & Intrafamiliar \\
15 & 17 & Individual & 1 & 48 & $\mathrm{~F}$ & Desconhecida & Extrafamiliar \\
\hline & & & & & & &
\end{tabular}




\section{Idade dos adolescentes, de suas vítimas e contextos do abuso}

Com base na referida tabela, pode-se destacar que a idade dos adolescentes ofensores oscilou entre 12 e 17 anos, cujas idades das vítimas variaram entre 3 anos e 48 anos de idade. Aqueles adolescentes que praticaram ofensa sexual no contexto extrafamiliar a idade de suas vítimas variou entre 11 anos (indivíduos na puberdade) e pessoas adultas. Os adolescentes que cometeram ofensa no ambiente intrafamiliar, por outro lado, eram mais jovens e suas idades correspondem ao intervalo entre 12 e 16 anos. As vítimas desses adolescentes tinham entre 4 e 9 anos de idade, ou seja, todas crianças. Os abusos cometidos em contexto institucional foram praticados por dois adolescentes, um de 14 e outro de 15 anos de idade. As vítimas tinham entre 3 e 9 anos, sendo que o adolescente mais velho abusou de três vítimas.

\section{Os adolescentes e a relação com as vítimas}

No que tange à relação entre os ofensores e suas vítimas, segundo dados apresentados na tabela, do total de adolescentes $(n=15)$, a maior parte deles $(n=10)$ já conhecia a pessoa que abusou. Além disso, metade desses adolescentes $(n=5)$ cometeu a ofensa no contexto intrafamiliar, enquanto os demais se subdividiram entre o abuso cometido no contexto extrafamiliar $(n=3)$ e institucional/abrigo $(n=2)$. Os outros adolescentes $(n=4)$ não conheciam suas vítimas e todos os abusos foram praticados no ambiente extrafamiliar. Em apenas um caso esta informação não estava disponível no processo.

\section{Idade dos adolescentes e prática do ato ofensivo}


A idade dos adolescentes quando analisada em relação à pratica do ato ofensivo não mostrou disparidade. Nos abusos cometidos de forma individual $(n=12)$ a média de idade dos adolescentes foi de 15,3 anos, ao passo que os abusos praticados de modo coletivo $(n=$ 3), os adolescentes tinham em média 15 anos de idade.

\section{Sexo e número de vítimas}

É possível verificar que do total de vítimas $(n=19)$, apenas duas eram do sexo masculino e tinham onze e oito anos. As femininas $(n=17)$, em contrapartida, oscilaram entre quatro e 48 anos de idade. Pode-se constatar, portanto, que em dois casos, um mesmo adolescente respondeu pelo ato infracional contra três diferentes pessoas do sexo feminino (adolescente 2, que abusou de três meninas, cuja média de idade foi de 12 anos; e adolescente 8, que também abusou de três meninas, porém de menor idade: média de 4,3 anos).

\section{Discussão}

Os resultados encontrados coincidem com os dados de estudos estrangeiros no que diz respeito à diversidade do perfil dos adolescentes que cometem ofensa sexual (Hunter, 2012a; Kemper \& Kistner, 2007; Kjellgren et. al, 2006) e às possíveis repercussões sociais, contextuais e judiciais que o fenômeno envolve (Bianchini \& De Antoni, 2012; Meng Chu \& Thomas, 2010). Mesmo sendo esta uma amostra reduzida e as pesquisas nacionais escassas para embasar a análise, o levantamento ajudou a dimensionar o problema. Isto é, apresentou uma estimativa dos processos pertinentes à Vara da Infância e da Juventude, relativos à ofensa sexual praticada por adolescentes, em um intervalo de cinco anos e quatro meses. 
Esses achados revelam que o número de registros sextuplicou em quatro anos, período compreendido entre 2008 e 2011. Em contrapartida, houve uma rápida redução em 2012 e a retomada da tendência ascendente no ano seguinte. As constatações são compatíveis às apresentadas pela Secretaria de Direitos Humanos da Presidência da República (SDH-PR, 2015), que aponta um índice elevado de denúncias relativas a abuso sexual contra crianças e adolescentes, somente no primeiro trimestre de 2015.

As explicações para a subida no número de denúncias podem estar relacionadas a dois eventos: às campanhas elucidativas a respeito da violência sexual e ao combate à pedofilia. Ambas são estratégias que têm contribuído para as revelações de abuso no contexto brasileiro, sobretudo nos últimos anos. Além disso, a conscientização acerca do papel das políticas públicas na prevenção de atos ofensivos e a necessidade de responsabilização dos autores da violência vêm crescendo (Costa \& Costa, 2013) e estão ajudando a mudar um cenário de impunidade. Assim, as iniciativas apontadas colaboram para dar visibilidade e divulgar a extensão do fenômeno.

Especificamente quanto à escolha das vítimas por parte dos adolescentes, pode-se perceber que o abuso contra crianças ocorreu tanto no contexto intrafamiliar como no institucional. Esse dado sugere que os autores das ofensas, em ambos os ambientes, já possuíam vínculo com as mesmas. Investigações sobre o tema realizadas por Habigzang, Azevedo, Koller e Machado (2006) apontam que as violações cometidas no ambiente intrafamiliar são protagonizadas, em grande parte, por um membro da família ou alguém da confiança da vítima. Situação semelhante parece ocorrer com aquelas que viviam em instituições de acolhimento.

Tais instituições, chamadas informalmente de abrigo, se destinam a receber provisoriamente crianças e adolescentes afastados do convívio familiar em virtude de abandono ou pelo fato dos responsáveis estarem impossibilitados de cumprir o papel de 
cuidadores. Apesar dos locais serem espaços de acolhimento e proteção, eventualmente reproduzem situações de violência (Carinhanha \& Penna, 2012) e abuso, naturalizando as relações de dominação e poder. Infere-se, portanto, que as estratégias de aproximação ou coação dirigidas às crianças tenham sido mais sutis do que as usadas contra as vítimas desconhecidas, em virtude de algum vínculo pré-existente.

Os achados corroboram o estudo de Kemper e Kistner (2007). Os autores, com base em uma investigação realizada em arquivos da justiça juvenil americana sobre 296 sentenciados, concluíram que há uma inclinação por parte de abusadores de infantes a eleger vítimas de suas relações, enquanto aqueles que ofendem pessoas de sua faixa etária, geralmente recorrem a desconhecidos. Eles destacam ainda que quando estes jovens cometem violência sexual contra outros jovens, preferem indivíduos do sexo feminino o que coincide, em parte, com o levantamento efetuado.

Além disso, a análise indica que em algumas ofensas ocorridas no contexto extrafamiliar, havia vínculo entre o adolescente e a vítima. Em quatro casos, porém, a pessoa vitimada era totalmente desconhecida dos perpetradores. Essa informação permite supor que o abuso praticado fora do ambiente familiar também possa ter como alvo alguém próximo. Por outro lado, aquelas pessoas que sofreram agressão no contexto extrafamiliar e não conheciam os autores da agressão eram do sexo feminino e maiores de idade, o que supõe o uso de uma abordagem mais invasiva por parte do perpetrador. Nestes casos, não é incomum o uso de violência durante a abordagem sexual, segundo o estudo conduzido por Hunter et al. (2000), cujas conclusões também referem a preferência desses perpetradores por vítimas do sexo feminino.

Especificamente sobre a média de idade dos adolescentes autores das violências, o levantamento apontou uma proximidade muito grande entre as médias das idades dos jovens que praticaram os atos no contexto intrafamiliar e institucional: 14,6 e 14,5 anos, 
respectivamente. Em contrapartida, aqueles envolvidos nos abusos extrafamiliares eram mais velhos - cerca de um ano e dois meses - quando comparados aos demais. Para tentar entender essa diferença seria preciso mais dados sobre o histórico dos jovens e de suas transgressões. Todavia, a hipótese para interpretar esse dado está apoiada no levantamento de Hunter (2012a). Após analisar diferentes investigações, o autor concluiu que os abusos executados fora do ambiente familiar, cujo alvo são outros adolescentes ou adultos, têm como protagonistas indivíduos com características antissociais e com déficits de competência social. Eles apresentam uma trajetória mais extensa de problemas com a justiça e mais diversificada, como furtos e roubos, o que explicaria o envolvimento em outros tipos de crimes antes das ofensas.

Quanto à prática do ato abusivo, constatou-se que a maioria dos episódios foi realizada de forma individual. Entretanto, os eventos que tiveram como autores mais de um adolescente foram praticados no contexto extrafamiliar. As vítimas, por sua vez, eram conhecidas dos jovens em dois casos e, somente em um, era desconhecida. Segundo o estudo empreendido por Kjellgren et al. (2006), que consistiu em um levantamento sobre ofensores registrados no departamento de Serviço Social do governo da Suécia, em 2000, a agressão cometida em parceria - ou seja, efetuada simultaneamente por mais de um adolescente costuma vitimar indivíduos conhecidos e que não estejam na fase da infância. Esse dado coincide com os achados do presente estudo, pois todos aqueles que sofreram um ataque coletivo estavam na puberdade ou na adolescência. Tal achado sugere a necessidade de investimentos em prevenção dirigidos aos adolescentes ofensores e aos adolescentes vítimas (Murrie, 2012), bem como a detecção dos fatores de risco associados a esse tipo de ataque (Spice, Viljoen, Latzman, Scarola \& Ullman, 2012; Worling \& Curwen, 2001).

Por fim, constata-se que o ato sexual abusivo praticado por um adolescente não ocorre de modo isolado. Ele é um fenômeno complexo que faz parte de um continuum (Ryan, 
2012) e por isso é importante que sejam investigados os fatores de risco e de proteção, bem como as chances de reincidência implicadas nas situações (Spice et al., 2012; Worling \& Langton, 2012;). O checklist denominado ERASOR (Estimate of Risk of Adolescent Sexual Offense Recidivism), por exemplo, é um instrumento dirigido a estimar o risco de reincidência de agressões sexuais cometidas por adolescentes que se baseia em fatores de risco relativos à conduta sexual (Worling \& Curwen, 2001).

Do ponto de vista das decisões judiciais referentes a tais atos infracionais, o ERASOR é um recurso que pode servir de apoio às decisões dos magistrados no contexto brasileiro em virtude da riqueza de detalhes que oferece. Há questões presentes no checklist que ajudam a identificar aspectos intra e interpessoais do jovem, como seus interesses e comportamento, seu histórico de crimes, seu funcionamento psicossocial e o contexto social em que está inserido (Worling \& Curwen, 2001). O somatório dessas informações, uma vez agregado aos processos, pode contribuir para a escolha da medida socioeducativa e para o tratamento mais adequado do adolescente. Os fatores de risco, consequentemente, ajudam a fundamentar as resoluções dos intérpretes da lei, pois oferecem subsídios à tomada de decisões.

O campo da Psicologia, conforme discutido, dispõe de recursos para intersecções com a área do Direito sobre o tema. A visão ampliada e dinâmica da ciência psicológica, por meio de um instrumental apropriado sobre o fenômeno da ofensa sexual, complementa o olhar pragmático do saber jurídico. A interlocução entre as duas disciplinas, aliada à perspectiva dos direitos humanos (Harris et al., 2015; Machado, 2003), portanto, é positiva e promissora no sentido de integrar os conhecimentos, revelando outras possibilidades interpretativas e novas posturas por parte do judiciário frente aos atos infracionais cometidos pelos adolescentes. 


\section{Considerações finais}

Os dados provenientes do estudo não podem ser generalizados em função do número reduzido de processos e do conteúdo presente nestes documentos. Constatou-se, por exemplo, que informações sobre a história pregressa dos sujeitos, das relações familiares e da rede social a qual pertencem são inexistentes. Essas informações ajudariam a contextualizar melhor os episódios e a expandir a compreensão sobre os autores da violência.

Por outro lado, as variáveis apresentadas neste artigo oferecem uma síntese do comportamento do adolescente autor de ofensa sexual e representam uma aproximação entre o campo da Psicologia e contexto judiciário. Neste sentido, o trabalho possibilitou conhecer algumas características dos jovens que cometem ofensa sexual, o ambiente no qual ocorrem as violações, o perfil das vítimas e o tipo de vínculo existente entre elas e os perpetradores.

No que tange à execução da investigação, propriamente dita, ainda é preciso superar alguns obstáculos, como o modo de acessar os processos e a coleta de dados. A inacessibilidade a arquivos sigilosos pode constituir um empecilho para a realização de análise documental em instituições públicas. Muitas vezes, em virtude do volume de tarefas nesses estabelecimentos, a solicitação dos autos e a exploração do material constituem demandas extraordinárias que, por sua vez, exigem tempo e empenho dos funcionários.

Apesar das dificuldades mencionadas, é importante incentivar pesquisas nessa área. Tanto sob o aspecto quantitativo como qualitativo, há uma escassez de referências a respeito do autor de ofensa sexual no Brasil, sendo necessário recorrer à literatura internacional (Costa et al., 2011; Penso, Conceição, Costa \& Carreteiro. 2012). Este é, portanto, um desafio a ser enfrentado, mas não o único.

É preciso criar, em diferentes regiões brasileiras, espaços de atendimento psicossocial às famílias e aos adolescentes envolvidos em episódios dessa natureza, tendo em vista tratar-se de um fenômeno que precisa de uma abordagem sistêmica e plural. $\mathrm{O}$ 
Distrito Federal é uma exceção, na medida em que conta com um serviço de saúde mental destinado não somente às vítimas como aos perpetradores infanto-juvenis e às suas famílias (Costa et al., 2013). Contudo, inexistem projetos dirigidos ao acompanhamento pósintervenção e à prevenção de novos casos (Costa et al., 2011). Aqueles jovens que cometem ofensa sexual merecem um olhar menos preconceituoso e coercitivo e mais continente. Significa dizer que não basta cuidar de quem sofre a violência, se ao agressor não for oferecido atendimento, cuidado, proteção, responsabilização e a possibilidade de reparação.

Essas medidas são essenciais para quem se encontra em pleno processo de desenvolvimento e comete um ato infracional, como a ofensa sexual (Penso et al., 2012). O risco que a sociedade corre em não dar a devida atenção ao problema é o de contribuir para a perpetuação dos comportamentos abusivos e para a legitimação da privação de liberdade como única forma de conter tais condutas, apesar da legislação avançada e da doutrina de proteção integral que vigora no país. 


\section{Adolescente considerado autor de ofensa sexual: Proteção, responsabilização e medidas socioeducativas}

Resumo. Este artigo discute a importância de se promover a proteção e a responsabilização de adolescentes considerados autores de ofensa sexual, com base no Estatuto da Criança e do Adolescente (ECA), com o intuito de evitar a reincidência. Por ser considerado um novo modelo de responsabilização, o ECA constitui o aparato jurídico indicado para enfrentar o preconceito e as discriminações dirigidas aos adolescentes, sobretudo os que se envolvem em transgressões dessa natureza. O silêncio por parte da família da vítima e do agressor, o desconhecimento a respeito das instituições que acolhem as denúncias e as dificuldades dos profissionais do campo da saúde e do judiciário para lidar com o problema são barreiras a serem transpostas. Além disso, é fundamental prevenir a estigmatização do adolescente e respeitar seu momento de desenvolvimento, com o intuito de não o comparar a adultos que cometem episódios semelhantes. $\mathrm{O}$ texto trata ainda sobre alternativas interventivas dirigidas aos adolescentes e suas famílias.

Palavras-chave: adolescente, ofensa sexual, proteção, responsabilização

Abstract. This article discusses the importance of promoting the protection and accountability of adolescents considered sexual offense authors, based on the Child and Adolescent Statute (ECA), in order to prevent a recurrence. To be considered a new model, the ECA is the legal apparatus indicated to face prejudice and discrimination directed at adolescents, especially those who engage in such transgressions. The silence from the family of the victim and the aggressor, the unawareness of the institutions that receive complaints and difficulties of professionals in the health field and the judiciary to deal with the problem are barriers to be overcome. In addition, it is essential to prevent adolescent stigmatization and respect their time of development, in order to not compare it to adults who commit similar episodes. The text also deals with interventional alternative directed to adolescents and their families.

Keywords: adolescent, sexual offense, protection, accountability

"Adolescentes em conflito com a lei" é um tema que tem provocado, nos últimos anos, discussões a respeito da efetividade das medidas socioeducativas e da redução da idade penal para inibir a prática de atos infracionais no contexto brasileiro (Monte, Sampaio, Rosa Filho \& Barbosa, 2011). O diálogo entre distintas áreas - como o Direito e a Psicologia tem aumentado, e está ajudando a aprofundar o debate acerca das contradições que vigoram no sistema socioeducativo (Alves, Pedroza, Pinho, Presotti \& Silva, 2009), para não dizer na própria sociedade, e em sua forma de enfrentar o fenômeno da violência e de lidar com o adolescente infrator (Conceição, 2010). 
Embora pessoas entre 12 e 18 anos sejam mais vítimas do que autores de violência no Brasil (Borges \& Cano, 2014), as transgressões realizadas neste período da vida não podem ser ignoradas, sob o risco de tornarem-se intensas e persistentes (Farrington, Loeber \& Jolliffe, 2008). Segundo o Estatuto da Criança e do Adolescente (ECA), o Estado tem a incumbência de proteger, reeducar e ressocializar o indivíduo em caso de prática infracional, sem dispensar sua responsabilização pelo ato cometido (Brasil, 1990; 2010). Entretanto, sob certas circunstâncias, a expectativa de punição tende a prevalecer (Conceição, 2010). A agressão de natureza sexual - denominada de abuso sexual no contexto brasileiro (Brasil, 1990; 2010) ou ofensa sexual no internacional, é uma destas situações, cuja conduta do jovem costuma ser veementemente repudiada e as reações de intolerância são comuns (Ryan, 2012).

A ofensa/abuso sexual é definida(o) como "todas as formas de atividades sexuais, nas quais, as crianças e adolescentes não têm condições maturacionais e psicobiológicas de enfrentamento, transgredindo assim, as normas sociais, morais e legais" (Habigzang, Ramos \& Koller, 2011, p.467). Pode ser praticado com o emprego de violência física e/ou verbal, sob coerção ou com estratégias de manipulação (American Psychiatric Association, 1999) conduzidas por meio de relações de poder e de confiança estabelecidas entre o agressor e sua vítima (Habigzang et al. 2011).

Importante mencionar que esse ato, quando praticado por adolescente, não constitui em si um diagnóstico, um transtorno ou uma condição, mas um comportamento (Worling \& Langton, 2012) que precisa ser compreendido sob a perspectiva desenvolvimental, inserido em um contexto psicossocial (Harris et al., 2015). A visão do adolescente em processo de desenvolvimento auxilia na construção de um plano interventivo adequado e compatível à sua idade, tendo em vista que pessoas no período da adolescência são mais responsivas ao tratamento do que quem já atingiu a adultez (Ryan, 2012). 
Reconhecendo tratar-se de um assunto relevante e ainda pouco explorado pela literatura no contexto nacional (Costa et al., 2013), o presente texto busca discutir os dilemas que envolvem o ato sexual ofensivo cometido por adolescente e as ações legais destinadas a responder aos episódios e evitar sua repetição. Primeiramente, são apresentadas noções do Estatuto da Criança e do Adolescente e aspectos contextuais; depois, as diretrizes preconizadas pelo Estatuto relacionadas à notificação, proteção e responsabilização do adolescente. Por fim, discute-se a reincidência e a aplicação de medidas socioeducativas.

\section{Infância e ECA: antecedentes e desdobramentos da lei 8.069}

A noção que temos de infância, atualmente, é bastante diferente a de outrora, muito embora o conceito seja recente e constitua uma invenção da era moderna. Segundo Ariès (1981), até o século XII e XIII inexistia na Europa um consenso sobre o termo. A compreensão que a fase infantil é particularmente distinta a do universo adulto, e que a criança necessita ser cuidada e resguardada quanto à sua sexualidade, ocorreu somente a partir do séc. XVII, precipitando uma reorganização nas famílias e na sociedade (Ariès, 1981).

No Brasil, tal entendimento provocou mudanças no campo legislativo ao final do século XX, quando a proteção de indivíduos menores de 18 anos de idade ganhou impulso. A Constituição de 1988 adotou a doutrina de proteção integral à criança e ao adolescente, elevando-os à condição de cidadãos e, consequentemente, de sujeitos de direitos em processo peculiar de desenvolvimento (Brasil, 1990; 2010) e delegando à família, à sociedade e ao Estado a tarefa de zelar pelo seu bem-estar.

O ECA é fruto de um processo social, histórico e cultural sem precedentes. Isto porque a filosofia precursora do Estatuto, presente no Código de Menores que vigorou desde 1979, estava alicerçada em uma visão segregadora e preconceituosa sobre a população 
infantil (Santos, 2010). De acordo com Abreu e Martinez (1996), a denominação "menor" era utilizada para se referir principalmente às crianças e aos adolescentes oriundos de classe social menos favorecida, cujo comportamento era associado com frequência à delinquência e à transgressão. E foi somente a partir da década de 80 que o papel do Estado começou a ser questionado frente à educação, à mortalidade infantil e à falta de políticas públicas inclusivas para esses jovens (Santos, 2010).

O Estatuto representa um amplo mecanismo dirigido a garantir os direitos à população infanto-juvenil, no sentido de fazer cumprir as diretrizes constitucionais. Sua instauração extrapolou fronteiras e permitiu que outros países da América Latina se mobilizassem para a implementação de reformas legislativas, conforme aponta o Plano Nacional de Enfrentamento da Violência Sexual contra Crianças e Adolescentes (2013). Segundo o documento, o ECA deu início a modificações no sistema de justiça e de segurança para crianças e adolescentes com a criação de Juizados da Infância e da Juventude, assim como Núcleos Especializados no Ministério Público e na Defensoria Pública, além de delegacias especializadas tanto para atendimento às vítimas, quanto para os autores de violência.

A organização do ECA compreende três sistemas de garantia, denominados: primário, secundário e terciário. O sistema primário abarca as políticas de atendimento a crianças e adolescentes; o secundário trata das medidas de proteção relativas àqueles que estão em situação de risco pessoal e social, isto é, vítimas que tiveram seus direitos violados; e o sistema terciário é destinado aos adolescentes em conflito com a lei e, consequentemente, às medidas socioeducativas (Brasil, 1990; 2010).

De acordo com o ECA, toda a conduta definida como crime ou contravenção pelo Código Penal brasileiro é considerada ato infracional, cabendo à autoridade competente estabelecer a medida socioeducativa mais adequada ao adolescente (Brasil, 1990; 2010). 
Tais medidas são definidas em consonância ao tipo de delito, às condições sociofamiliares do indivíduo e aos programas e serviços disponíveis no município, no estado ou na região onde ocorrerá o cumprimento da mesma.

A sanção tanto pode ser branda e de caráter protetivo - conforme estabelece o artigo 101 do ECA - como mais rigorosa e restritiva de direitos, que prevê a internação em instituição reeducativa, a saber: advertência, obrigação de reparar o dano, prestação de serviços à comunidade, liberdade assistida, regime de semiliberdade e privação de liberdade ou internação (Brasil, 1990; 2010). Por outro lado, existe um descompasso entre as diretrizes preconizadas pelo Estatuto e sua plena efetivação (Conceição, 2010).

A discrepância se traduz na violação de direitos de grande parte dos adolescentes país afora, como o direito à alimentação, à moradia, à saúde, à educação e ao lazer. Sem ambientes protetivos e expostos à violência, esses jovens têm mais dificuldade de desenvolver ideais de cidadania e de valorização à vida (Alves et al., 2009) e maior chance de manifestar comportamentos transgressores. Portanto, o adolescente identificado como autor de ato infracional não é qualquer adolescente; ele tem posição socioeconômica e características definidas (Penso et al. 2012).

A prática infracional pode ser interpretada como resultado de inúmeras situações de violência e exclusão que selam o destino do jovem e o transformam em "desajustado social" (Penso et al. 2012). Segundo Porto (2010, p. 243) “... a suspeita exercida pelas instituições de controle social atinge, seletivamente, as camadas mais pobres da população", mesmo que indivíduos de extratos médio e alto pratiquem igualmente crimes, como os de natureza sexual. Além de subnotificadas, essas infrações não são associadas a adolescentes de status elevado; pelo contrário, há uma construção social, baseada em estereótipos, que conecta a pobreza à periculosidade (Porto). 
Apesar das diversas contradições que persistem na sociedade brasileira, Conceição e Penso (2015) reforçam que o Estatuto da Criança e do Adolescente continua a ser o aparato jurídico indicado para enfrentar o preconceito e as discriminações dirigidas a adolescentes pobres e marginalizados. Segundo as autoras, o Estatuto estabeleceu uma nova visão sobre o tema, uma vez que "em vez de proteger a sociedade dos menores infratores, propõe-se garantir a proteção à criança e ao adolescente na condição de seres em desenvolvimento" (p. 42).

Se a referida visão está de fato em vigor, cabe entender o modo pelo qual essa proteção pode ser garantida ao adolescente autor de ato infracional de caráter sexual. Por tratar-se de um comportamento que gera estigmatização, hostilidade e rechaço (Harris et al., 2015; Letourneau \& Miner, 2005; Ryan, 2012; Ward, Gannon \& Birgden, 2007) os cuidados devem ser redobrados, não somente em relação às vítimas de abuso, mas ao próprio perpetrador da ofensa (Jones, 2015; Worley et al., 2012). Uma das maneiras de reduzir as consequências nefastas do ato é recorrer a medidas de responsabilização, salvaguardando o indivíduo acusado (Costa, Marreco, Barros \& Chaves, 2015). Em outras palavras, o adolescente que comete uma ofensa sexual precisa ser protegido e responsabilizado, independentemente de sua trajetória de vida, origem social e nível educacional. Em virtude disso, o próximo tópico apresenta questões relativas à notificação do ato e as implicações para o adolescente e sua família após o procedimento.

\section{Notificar, proteger e responsabilizar}

São escassas as informações e os trabalhos relativos a atos sexuais ofensivos protagonizados por indivíduos jovens ou adolescentes, ainda que o assunto esteja sendo explorado e estudado há mais de trinta anos (Barroso, 2012; Ryan, 2012). Essa conclusão é também partilhada por Krahé, Tomaszewska, Kuyper e Vanwesenbeeck (2014) após a 
realização de um levantamento de dados a respeito do tema em 27 países da União Europeia. Os resultados indicam que há um número reduzido de investigações, tanto sobre vitimização sexual como sobre a prática de ofensa sexual, envolvendo pessoas entre 12 e 25 anos de idade. Além disso, segundo os autores, existe uma diversidade de metodologias, instrumentos e concepções teóricas utilizadas nos trabalhos que prejudicam a compreensão do fenômeno e o tornam nebuloso, aumentando o desconhecimento do que ocorre no continente europeu.

No território nacional não é diferente. As estatísticas são parciais, não há sistematização rigorosa das informações e, tampouco, uma categorização por faixa etária de autoria (Penso et al., 2012). Segundo Costa (2014), os preconceitos em relação ao assunto, o silêncio por parte da família da vítima e do agressor, o desconhecimento a respeito das instituições que acolhem as denúncias e as dificuldades dos profissionais do campo da saúde e do judiciário para lidar com o problema são barreiras a serem transpostas.

Por outro lado, a notificação compulsória de violência contra crianças e adolescentes, incluindo situações de abuso sexual, está em vigor desde a década de 1990, tendo por objetivo proporcionar a proteção imediata da vítima e prevenir danos secundários à saúde (Lima \& Deslandes, 2011). De acordo com o artigo 13 do ECA, "os casos de suspeita ou confirmação de maus-tratos contra criança ou adolescente serão obrigatoriamente comunicados ao Conselho Tutelar da respectiva localidade, sem prejuízos de outras providências legais” (Brasil, 2010, p.14). Além desta medida, o Ministério da Saúde ampliou, em 2001, a notificação compulsória para a ocorrência de maus-tratos atendidas pelo Sistema Único de Saúde (Lima \& Deslandes), demonstrando o empenho das entidades governamentais em proteger os indivíduos mais vulneráveis.

Desde então, há uma tentativa em padronizar os procedimentos em situações de violação física e sexual no país, bem como registrar o número de casos e implementar 
políticas públicas (Lima \& Deslandes, 2011). A notificação, portanto, não é importante apenas para a vítima, mas é essencial ao autor da violência (Costa, 2011). Em se tratando de adolescentes, Costa, Penso e Conceição (2015) alertam que é através dela que ocorre, concomitantemente, a proteção e a responsabilização do perpetrador. Embora o papel da justiça seja fundamental neste processo, diversas famílias optam por não recorrer à Lei (Smith et al., 2005).

A investigação realizada por Costa (2011), com famílias de adolescentes que cometeram ofensa sexual, demonstra que os genitores não procuram "espontaneamente nenhum órgão do sistema justiça para denunciar, nem mesmo o Conselho Tutelar” (p. 195). Tais famílias resistem em procurar a delegacia sob a alegação de serem mal recebidas e acusadas de negligência. Segundo a autora, o evento costuma ser silenciado e os próprios membros se encarregam de averiguar o ocorrido e adotar sanções punitivas e reparadoras.

Podem haver, inclusive, tentativas de minimizar o ato a fim de preservar o adolescente das instâncias judiciais, mesmo que a vítima pertença ao núcleo familiar do autor da violência (Smith et al., 2005). A imposição de limites e a construção de um esquema de vigilância para evitar nova situação de abuso também são atitudes comuns (Jones, 2015). Contudo, ter sob o mesmo teto o indivíduo abusado e o jovem que praticou a ofensa sexual constitui um enorme desafio, pois ambos precisam de proteção e cuidados que nem sempre o grupo familiar, sozinho, está preparado para oferecê-los (Penso et al., 2012; Worley et al., 2012).

Um dos procedimentos previstos no ECA, no enfrentamento do problema, é encaminhar o adolescente, juntamente com seus pais ou responsável, para programa comunitário e tratamento médico, psicológico ou psiquiátrico (Conceição \& Penso, 2015). A inclusão nesses espaços auxilia o processo de proteção e de responsabilização do infrator pelo ato cometido, ao mesmo tempo que orienta os progenitores após os eventos. 
Para Costa et al. (2011), o jovem "em função de sua idade e dos conflitos que sofre em família" (p. 455), necessita ser poupado de violências, sob o risco de repetir o mesmo modelo de comportamento no futuro. Assim, a responsabilização é parte de uma abordagem inclusiva e não segregadora que deve respeitar os direitos daqueles que, em determinadas circunstâncias, não foram capazes de respeitar os direitos dos outros (Ward, Gannon \& Birgden, 2007).

Escolher o melhor caminho para lidar com a situação é uma tarefa complexa. O temor em relação às medidas coercitivas dirigidas ao adolescente é outra razão que retarda a busca pelo sistema de justiça (Smith et al., 2005). Nos Estados Unidos, por exemplo, a proteção da sociedade tem prioridade frente à reabilitação do ofensor (Ryan, 2012), cuja legislação é bem mais rigorosa do que a brasileira.

Uma das sanções instituídas naquele país foi o registro público de jovens em um cadastro nacional de ofensores sexuais, com o propósito de garantir a proteção infantil contra possíveis atos violentos de natureza sexual (Harris et al., 2015). O referido registro tem gerado discussões e polêmicas, na medida em que a população adquiriu livre acesso a informações sobre o indivíduo acusado, como idade, histórico de transgressões, dados pessoais e até endereço (Harris et al.; Letourneau \& Miner, 2005; Ryan, 2012). As consequências desta disposição têm se estendido não apenas ao jovem, alvo de perseguições e hostilidade, mas aos demais membros de sua família, sujeitos a perder o emprego e a sofrer segregação social, entre outras adversidades (Harris et al.).

Neste contexto, o adolescente passou a ser tratado como um adulto em miniatura, cujo padrão de conduta considerada "anormal" representa uma ameaça aos cidadãos, exigindo rígidos mecanismos de controle (Zimring, 2004) que vão desde o uso de dispositivos eletrônicos (Harris et al., 2015) até o encarceramento (Ryan, 2012). Outro aspecto a ser mencionado é a popularização do termo ofensor sexual (sex offender) 
exaustivamente associado à figura do adolescente. De acordo com a literatura (Barbaree \& Marshall, 2006; Ryan), somente pessoas já submetidas a julgamento e condenadas poderiam ser identificadas dessa forma, excluindo os suspeitos ou aqueles que apresentam comportamento sexual desviante, mas não criminal.

Conforme as diretrizes presentes no texto das Nações Unidas sobre a prevenção da delinquência juvenil, intitulado de Diretrizes de Riad, classificar o jovem como delinquente ou pré-delinquente em nada contribui para a sua ressocialização, mas "favorece o desenvolvimento de pautas permanentes de comportamento indesejado" (Brasil, 2010, p. 279). Com base neste argumento, entende-se que denominar o adolescente que pratica um ato sexual ofensivo de "ofensor sexual" colabora para a sua estigmatização e prejudica a sua reabilitação (Harris et al., 2015).

Ryan (2012) acrescenta que utilizar esse termo ajuda a cristalizar uma visão equivocada e destrutiva do jovem, aumentando crenças imprecisas sobre a continuidade desta conduta na vida adulta. Grande parte dos adolescentes que cometem tal violência não volta a repeti-la (Ryan; Vandiver, 2006; Worling, 2012), por isso, equiparar o comportamento de um adolescente ao de um adulto implica desconsiderar seu processo de desenvolvimento, sua trajetória de vida, os aspectos contextuais e as possibilidades de transformação deste indivíduo (Barbaree \& Marshall, 2006; Seto \& Lalumière, 2010; Worling \& Langton, 2012; Zimring, 2004).

Trabalhos empíricos feitos em diferentes partes do mundo (Harris et al., 2015; Worling \& Langton, 2012) têm demonstrado que é um equívoco adotar sanções equivalentes para indivíduos desiguais (Wijk, Bullens \& Vermeiren, 2007). Assim, é preciso aprimorar o conhecimento a respeito dos adolescentes mais suscetíveis a repetir o comportamento ofensor, respeitando suas particularidades, ao invés de utilizar os mesmos procedimentos coercitivos que se usa com adultos (Ryan, 2012). 
Ao contrário da legislação americana, o ECA está alicerçado em um princípio pedagógico e ético, mais do que punitivo (Brasil, 1990; 2010), embora as medidas socioeducativas sejam frequentemente criticadas (Monte et al., 2011) e confundidas em sua essência. É importante lembrar o princípio da excepcionalidade e o da brevidade quanto ao sistema de responsabilização para evitar ao máximo a institucionalização de adolescentes (Brasil, 1990; 2010). Mesmo assim, a medida restritiva de liberdade tem vigorado e não são poucos os estabelecimentos ressocializadores que apresentam excesso de contingente, espaços inadequados para acolhimento e serviços de saúde e educação deficitários (Conceição, 2010). Para melhor discutir o tema, a seguir são apresentados aspectos relativos à reincidência e as medidas socioeducativas.

\section{Reincidência e medidas socioeducativas}

No Brasil, os recursos e parâmetros que embasam as decisões relativas às medidas socioeducativas, dirigidas a adolescentes em conflito com a lei, não são uniformes e podem variar de contexto para contexto. Segundo Maruschi, Estevão e Bazon (2012) há falta de instrumentos de avaliação para identificar os fatores mais associados à conduta infracional, bem como à sua repetição.

Cientes desta lacuna, as autoras Maruschi et al. (2012) realizaram uma investigação exploratória com 40 adolescentes em cumprimento de medida socioeducativa, no estado de São Paulo, com o intuito de avaliar os fatores de risco e as necessidades dos adolescentes, após a prática de ato infracional. $\mathrm{O}$ instrumento utilizado para atingir tal fim, denominado Youth Level of Service/Case Management Inventory (YLC/CMI), é um checklist de origem canadense que identifica diferentes níveis de risco para a persistência da conduta infracional.

De acordo com a investigação, $75 \%$ da amostra apresentou risco moderado, alto e muito alto para a manutenção do comportamento, cujas variáveis envolveram o uso de 
drogas, a companhia de pares com histórico semelhante e a precocidade no comportamento transgressor. As conclusões do estudo apontam que esses adolescentes necessitam de intervenções específicas e acompanhamento para superar as adversidades. No entanto, $25 \%$ da amostra foi classificada como baixo risco, sugerindo que os procedimentos jurídicos e institucionais deveriam ser breves e leves "de modo a, inclusive, evitar os efeitos da rotulação e da socialização nas instituições de controle" (p. 684).

Trabalho ainda mais recente foi realizado no Distrito Federal (Companhia de Planejamento do Distrito Federal [CODEPLAN], 2015) com 1.147 adolescentes que cumpriam medida socioeducativa em 2013. O estudo, que teve por objetivo relacionar prática infracional e medidas socioeducativas, apontou a educação e o esporte como os principais fatores responsáveis pela redução das chances de recidiva. Ao mesmo tempo, identificou que "os mais baixos percentuais de reincidência estavam entre os jovens que cumpriam medidas em meio aberto, quando comparados às medidas restritivas de liberdade (semiliberdade e internação)" (p. 6). O investimento em estratégias não restritivas de liberdade pode auxiliar a evitar a repetição de atos infracionais e favorecer o processo de recuperação do jovem. Para Conceição (2010), “a pena de reclusão é falha em seu aspecto correcional da conduta social. Tem sido sistematicamente observado que a sanção de restrição de liberdade cria sérios obstáculos à ressocialização, além de ferir direitos fundamentais do cidadão" (p.91). Quanto à reincidência, a autora destaca que a maioria dos adolescentes internados possui uma trajetória de pequenas transgressões, que culminam na prática de atos mais graves.

É preciso registrar que a escolarização e a profissionalização do adolescente fazem parte do contexto das medidas, assim como o atendimento personalizado, respeitoso à identidade e à singularidade de cada indivíduo (Monte et al., 2011). O ambiente designado para o cumprimento da medida socioeducativa influi diretamente na percepção do amanhã, 
na capacidade de fazer planos e no senso de responsabilidade do adolescente pela infração cometida.

A pesquisa da CODEPLAN (2015) revela, por exemplo, que o jovem em semiliberdade tem três vezes mais chance de ter planos para o futuro, do que aquele que está na internação. Outro dado relevante aponta que quanto menos restritiva for a medida socioeducativa, maior será a probabilidade de o adolescente entender que sua responsabilização é legítima. De outra sorte, “a internação aparece então como medida injusta, enquanto a medida em meio aberto aparentemente aumenta nos jovens a noção de responsabilidade pelo ato cometido" (p.15). Reconhecer o erro e entender que é justo responder por ele talvez seja o primeiro passo para efetivar a proposta ressocializadora contida no ECA, contanto que o adolescente perceba que sua aplicação não extrapola tal fim.

De acordo com Carpentier, Leclerc e Proulx (2011), somente alguns indivíduos que praticaram ofensas sexuais no período da adolescência irão persistir na carreira sexual delitiva ao atingirem a idade adulta. Hunter (2012a) entende que há subgrupos com características comuns, como os que buscam exclusivamente vítimas na fase da infância e os que procuram pessoas de sua própria faixa etária ou adultas. As razões para tais preferências dizem respeito aos antecedentes dos ofensores e costumam ajudar na identificação do tratamento mais adequado e na prevenção de recidivas (Hunter, 2012b; Kemper \& Kistner, 2007).

O estudo empreendido por Meng Chu e Thomas (2010) investigou as características, a versatilidade criminal e as taxas de reincidência de uma amostra de 156 adolescentes que cometeram ofensas sexuais, avaliados entre os anos de 1996 a 2007, no contexto forense de Singapura. Os adolescentes foram divididos em dois grupos: o primeiro, denominado de especialistas, reuniu apenas ofensores sexuais e o segundo, chamado de generalistas, era 
composto por adolescentes que haviam cometido diferentes tipos de crimes, além da ofensa sexual.

Os resultados apontaram que houve reincidência em ambos; porém, no grupo dos generalistas verificou-se que 1 em cada 5 adolescentes cometeu crimes com uso exacerbado de violência em um período de 2 anos e meio, diferentemente do grupo dos especialistas, com índices muito inferiores. Outra distinção disse respeito à escolha das vítimas. Os generalistas escolheram pessoas fora do seu círculo familiar para a prática das ofensas sexuais, ao contrário dos especialistas.

Ao que os estudos indicam, nem todo o indivíduo que praticou ofensa sexual necessita de uma sanção rigorosa. Intervenções adequadas ao tipo de ofensa e aplicadas em meio aberto podem funcionar para uma determinada categoria e contribuir para evitar a reincidência. $\mathrm{O}$ desafio reside em conciliar as especificidades de cada sujeito utilizando uma visão abrangente do desenvolvimento (Ryan, 2012), cuja expressão da sexualidade deve ser vista em processo (Hunter, 2012a).

É preciso ter disponíveis recursos intersetoriais e multidimensionais para que as instâncias estejam aptas e capacitadas a atender tanto quem sofre a violação, como quem a executa (Costa et al., 2011). O Estado, por sua vez, exerce um papel socioeducacional e sua missão é oferecer aos adolescentes que cometem ofensas não apenas medidas responsabilizadoras, mas também possibilidades de atenção e tratamento (Bianchini \& De Antoni, 2012).

O estudo comparativo realizado por Worling e Curwen (2000) aponta que somente 5\% de uma amostra 58 adolescentes que recebeu tratamento teve uma segunda acusação de ofensa sexual. Em compensação, no grupo constituído por 90 adolescentes não submetidos à intervenção, verificou-se que $18 \%$ deles foram acusados de um novo crime da mesma natureza, em um período aproximado de seis anos após o primeiro episódio. 
Instrumentos dirigidos a avaliar os riscos de reofensa vêm sendo desenvolvidos para detectar quais fatores de risco e de proteção colaboram para diminuir ou aumentar as chances de reincidência (Worling \& Langton, 2012). Há, portanto, a necessidade de estudos empíricos que deem suporte às estratégias interventivas e, posteriormente, aos programas preventivos. De acordo com Worling e Langström (2003), é preciso também uma sistematização dos dados, tornando mais eficiente a comunicação entre instituições, como o Sistema de Justiça e os profissionais da saúde.

\section{Considerações finais}

As situações de ofensa sexual constituem uma afronta ao desenvolvimento físico, psíquico, moral e sexual; à autonomia; à liberdade; e à dignidade do indivíduo (Brasil,1990; 2010). Trata-se de um fenômeno complexo e multideterminado, capaz de atingir pessoas de diferentes idades, etnias, religiões e contextos (Worley et al., 2012), cujas implicações e consequências se estendem à prática clínica, à política instaurada nos serviços de atendimento, ao modo de organização das sociedades, além da instância judicial (Chu \& Thomas, 2010).

No Brasil, é um tema ainda incipiente. Os trabalhos empíricos se referem, preferencialmente, às vítimas de violação em detrimento aos perpetradores (Bianchini \& De Antoni, 2012) e pouco mencionam sobre os que estão na adolescência (Costa et al., 2012). Para muitos desses jovens, a referida conduta é parte de um problema maior que envolve situações de violência intrafamiliar, bem como aspectos sociais, econômicos e ambientais (Penso et al., 2012).

Do ponto de vista da legislação, o Estado tem o papel de conter o comportamento do jovem identificado como agressor sexual; contudo, a tarefa de protegê-lo deve vir em primeiro lugar, sob princípios que regem o ECA e os direitos humanos (Brasil, 1990). Por 
esta razão, a aplicação de medidas socioeducativas ultrapassa a figura do "adolescente infrator", abrangendo instituições como família, escola e poder judiciário.

É preciso reconhecer que existe distanciamento entre o discurso ressocializador e a prática vivenciada a partir da decretação de uma medida socioeducativa, seja ela no meio aberto ou fechado. A ideia da responsabilização do jovem pela ação é fundamental e pode gerar efeitos positivos, entretanto, não se pode desconsiderar as dimensões dessas sanções na vida do adolescente.

Conforme demonstrado pela pesquisa da CODEPLAN (2015), as medidas socioeducativas podem ser interpretadas pelos adolescentes como válidas, desde que não cumpridas em estabelecimentos fechados. A resistência a esse contexto é compatível à falta de estrutura e de condições de saúde, educação, profissionalização, sem falar na violência, que existe na maioria das instituições (Conceição, 2010).

Não basta recolher o indivíduo e esperar que ele consiga, por si próprio, rever sua conduta ou perceber os danos causados a outrem. Primeiro, porque o tempo de internação é limitado e o ambiente em nada colabora para a reflexão, mas, ao contrário, acirra sentimentos de raiva, isolamento e exclusão (Conceição, 2010); segundo, pelo fato de não haver condição de atendimento e tratamento em ambiente de internação, uma vez que é contra indicado a identificação do jovem e é dever do Estado proteger sua integridade (Brasil, 1990; 2010); terceiro, porque a equipe de profissionais dificilmente está habilitada e capacitada para atender à demanda.

Ademais, inexistem programas dirigidos ao acompanhamento pós-intervenção e à prevenção de novos casos. Razões para a implementação das ações não faltam, até porque as medidas voltadas a resguardar os direitos dos adolescentes não têm sido suficientes para lhes garantir uma vida digna, sem negligência e livre de violências. Aqueles jovens que cometem ofensa sexual merecem um olhar menos preconceituoso e mais continente. O risco 
que a sociedade corre em não dar a devida atenção ao problema é o de contribuir para a perpetuação dos comportamentos abusivos e para a legitimação da privação de liberdade como forma de inibir tais condutas, apesar da legislação avançada e da doutrina de proteção integral que vigora no país. 


\title{
Ofensa sexual perpetrada por adolescentes: Percurso e intervenção no contexto português e no brasileiro
}

\begin{abstract}
Resumo. Comportamentos delinquentes cometidos na juventude, como a ofensa sexual, constituem um problema de saúde pública que envolve o sistema de justiça e a sociedade civil, atingindo pessoas de diversas culturas. O presente texto aborda os fatores de risco associados à conduta sexual ofensiva perpetrada por jovens e adolescentes, as medidas interventivas mais comuns e a necessidade de implementação destas práticas em diferentes contextos. Para diminuir os efeitos deletérios dos episódios e evitar sua reincidência, é preciso construir programas de atendimento não apenas às vítimas, mas também aos autores da violência. Em virtude da lacuna acadêmica e científica detectada em alguns países - como Portugal e Brasil - ressalta-se a importância de investigações na área, sobretudo as relacionadas a eficácia das ações terapêuticas com os agressores. Em ambas as nações, os serviços públicos de atendimento são relativamente recentes, escassos e limitados geograficamente, o que demonstra a necessidade de mais investimentos em reabilitação e prevenção da reincidência.

Palavras-chave: adolescente ofensor sexual; reincidência; fatores de risco; intervenção
\end{abstract}

Abstract. The delinquent behavior committed in youth time, such as sexual offense, constitute a public health problem involving the justice system, civil society and affects people of diverse cultures. To decrease the deleterious effects of the episodes and to prevent their recurrence, we must build care programs not only the victims but also the perpetrators of violence. This paper is about the risk factors associated with offensive sexual conduct perpetrated by young people and adolescents, the most common interventional measures and the need to implement these practices in different contexts. Due to the academic and scientific gap detected in some countries - such as Portugal and Brazil - emphasizes the importance of research in the area, especially those related to effectiveness of therapeutic actions with the offenders. In both nations, the public health service are relatively recent, scarce and limited geographically, which shows the need for more investment in rehabilitation and prevention of recidivism.

Keywords: adolescent sexual offender; recidivism; risk factors; intervention

A conduta infracional apresentada por jovens é um tema que tem despertado o interesse de investigadores de diversas áreas e de distintas nacionalidades. Tal fenômeno, relativamente frequente, deriva da interação entre fatores de risco e é comum seu declínio ocorrer ao final da adolescência e início da vida adulta (Farrington et al., 2008). Alguns indivíduos são menos propensos a mudar de trajetória, o que exige a identificação das variáveis associadas à manutenção do comportamento e à sua repetição. Assim, esse é um campo de trabalho que engloba não somente medidas para a avaliar a reincidência como para 
aprimorar programas interventivos para evitá-la. De acordo com Harris, Lockwood e Mengers (2009), o termo reincidência equivale a prática de uma nova infração por alguém que já tenha, anteriormente, cometido algum delito. Contudo, há fatores que influenciam a compreensão do fenômeno e que podem gerar ambiguidades no momento de definir se houve ou não repetição do ato.

O primeiro fator diz respeito ao tipo de fonte e de instituição que fornece as informações; o segundo engloba os parâmetros usados para medi-la, ou seja, alguns investigadores consideram a mera acusação de um novo crime, enquanto outros, a condenação ou o encarceramento; o terceiro, e não menos importante, se relaciona a diferentes períodos de follow-up apresentados nos estudos, associados ao estilo e à severidade dos delitos praticados (Daly, Bouhours, Broadhurst \& Loh, 2013). Por outro lado, usar dados oficiais ou dados de autorrelato dá origem a resultados muito diferentes. A operacionalização dos conceitos, critérios e paradigmas que envolvem o tema da reincidência, portanto, influenciam os resultados e a maneira como estes são interpretados (Budd \& Desmond, 2014).

No que diz respeito à eficácia das intervenções, Cunneen e Luke (2007) entendem que os critérios que embasam os estudos atuais a esse respeito são, por vezes, pouco claros. Os autores questionam o modo como as análises são realizadas, a metodologia e os parâmetros utilizados para sustentar conclusões acerca da eficácia das ações interventivas. Para eles, as avaliações relativas à eficácia do sistema de justiça juvenil costumam se restringir à presença ou ausência de reofensas, sem levar em consideração diferentes aspectos implicados em um processo terapêutico, por exemplo. Essa limitação os fez acrescentar medidas de caráter qualitativo às suas investigações com o intuito de detalhar em profundidade a percepção de indivíduos e grupos submetidos a intervenções. 
Conhecer os percursos e os fatores de risco e proteção pode auxiliar na construção de programas que considerem a recidiva uma ferramenta avaliativa da eficácia da intervenção, e sugerir outros recursos além deste. Para Cunneen e Luke (2007), identificar os fatores associados à desistência do comportamento delinquente é tão relevante quanto os índices de recaída e pode informar sobre medidas que devem ser promovidas para validar a eficácia das intervenções a longo prazo.

Entre os comportamentos delinquentes, a ofensa ou abuso sexual cometido por adolescentes é um dos fenômenos que tem gerado preocupações em termos sociais e científicos, devido a consequências negativas, tanto para as vítimas quanto para os perpetradores (Ryan, 2012; Worling \& Langton, 2012). Esta forma de violência é definida como todo o ato sexual que empregue violência física e verbal, além de estratégias de manipulação e coação contra as vítimas (American Psychiatric Association, 1999). A prática pode incluir atitudes sexualizadas, com ou sem contato físico, que causem danos e prejuízos àquele que é subjugado e cuja ocorrência se dê em ambiente intra ou extrafamiliar (Hatzenberger, Habigzang \& Koller, 2012). Trata-se, resumidamente, de qualquer ato sexual que ocorra sem consentimento, sem igualdade e como resultado de uma coerção (Barroso, 2012; Ryan).

Apesar de não ser um tema novo, o abuso sexual cometido por adolescentes começou a ser investigado com vigor a partir da década de 90, no contexto canadense (Barbaree $\&$ Marshall, 2006). Os estudos que abordam os fatores de risco para o comportamento sexual ofensivo e sua repetição são ainda mais recentes e reportam-se, em sua grande maioria, a populações adultas. A falta de investigações sobre a temática com pessoas entre 12 e 20 anos de idade provocou, como afirmam alguns autores (e.g. Hunter, 2012a; Spice et al., 2012), uma lacuna científica que está sendo preenchida, principalmente, nas últimas décadas. 
Em virtude do crescente interesse pelo assunto e das controvérsias que o envolvem, o presente texto apresenta dados sobre a reincidência e as características dos jovens que cometem ofensa sexual, bem como os fatores de risco para a repetição dos atos ofensivos e as avaliações destinadas a detectá-los. Em seguida, aborda a reincidência de comportamentos sexuais ofensivos protagonizados por jovens ou adolescentes e os programas interventivos dirigidos a essa população, nos contextos português e brasileiro. Finalmente, são traçadas considerações sobre o sistema de justiça juvenil de cada um destes dois países e a necessidade de inserção de projetos interventivos nestes contextos.

\section{A dimensão do fenômeno e as caraterísticas dos jovens que cometem ofensa sexual}

Estima-se que cerca de $30 \%$ de todos os casos de ofensa sexual sejam protagonizados por pessoas menores de 18 anos de idade (Oliver, 2007). Esse número pode ultrapassar os $50 \%$ quando se refere a ofensas perpetradas exclusivamente contra crianças (Barbaree \& Marshall, 2006; Ryan, 2012), o que explica as diferenças estatísticas sobre a ocorrência dos episódios.

Quanto aos índices de reincidência, Caldwell (2010) indica uma taxa em torno de $7,08 \%$ para ofensas sexuais e 43,4\% para as não sexuais, entre jovens com antecedentes de conduta sexual delitiva. Significa dizer que os reincidentes têm uma probabilidade seis vezes maior de cometerem atos de ordem não sexual do que sexual. Portanto, os adolescentes que apresentam comportamento sexual ofensivo constituem uma categoria heterogênea e, mesmo demonstrando similaridades, diferem em várias dimensões (Butler \& Seto, 2002; Hunter, 2012a; Worling \& Langton, 2012), o que exige atenção especial na identificação de fatores que levam a esse percurso (Worling, Bookalam \& Litteljohn, 2012).

O trabalho realizado por Marshall e Marshall (2000) aponta, em termos genéricos, que a infância de pessoas que cometem ofensas sexuais é marcada por variadas formas de 
abuso, negligência ou rejeição, que resultam em uma intensa fragilidade. Segundo os autores, esse aspecto originaria um empobrecimento nas habilidades interpessoais, geraria baixa autoestima e desejo de afeição, tendo como consequência o uso inapropriado da sexualidade. No que tange às características familiares, é comum haver padrões problemáticos de comunicação, disciplina inconsistente e inabilidade parental para lidar com o comportamento do jovem. O ambiente de convivência é habitualmente deficitário, em termos de trocas afetivas positivas e de modelos saudáveis de interação (Worley et al., 2012).

No mesmo sentido, a meta-análise empreendida por Seto e Lalumière (2010), baseada em 59 estudos com jovens agressores sexuais e jovens agressores não sexuais, revela algumas particularidades. O primeiro grupo apresenta uma trajetória mais acentuada de episódios de violência física, sexual e negligência, maior isolamento social, exposição precoce à pornografia e interesses sexuais atípicos, diferentemente do segundo grupo.

Para além disso, há distinções entre aqueles indivíduos que cometem somente ofensa sexual e aqueles que praticam, também, outros tipos de violência, conforme pode ser observado na investigação de Butler e Seto (2002). A referida investigação, realizada com 114 adolescentes, deu-se em duas etapas. A primeira teve por objetivo identificar as semelhanças a partir do histórico de práticas delituosas com base em três distintos grupos: adolescentes que haviam cometido ofensa sexual $(n=32)$, adolescentes com trajetória de comportamento violento e não-violento, mas sem registro de ofensa sexual ( $n=48)$, e por fim, um grupo de adolescentes que tinha cometido atos sem violência e não sexuais $(n=34)$.

Os resultados demonstraram que adolescentes de todos os grupos apresentavam problemas de comportamento. Na segunda etapa, os autores buscaram distinguir os adolescentes que haviam praticado apenas delito sexual (sex-only) daqueles que tinham outros crimes associados aos atos sexuais ofensivos (sex-plus-offender). Os resultados 
indicaram que os jovens denominados sex-only demonstraram ter mais habilidades e atitudes pró-sociais, bem como baixo risco de reincidência. Em contrapartida, no grupo dos sex-plusoffender, detectou-se uma chance maior destes indivíduos terem transtorno de conduta, características antissociais e risco elevado de reincidência.

Diante desses achados, entende-se que existem evidências empíricas suficientes para diferenciar jovens quanto ao comportamento sexual ofensivo (Hunter, 2012a). No entanto, eles são muitas vezes considerados um grupo homogéneo, ou equiparados a adultos com histórico de agressão sexual (Murrie, 2012; Ryan, 2012; Spice et al., 2012).

As ofensas sexuais perpetradas na fase da adolescência necessitam de um quadro referencial que considere as questões cognitivas, comportamentais e emocionais, próprias dessa etapa do desenvolvimento. Uma visão contextualizada a respeito da maturação sexual pode permitir que o fenômeno, especialmente nos casos dos "sex-only", seja entendido como parte de um processo, suscetível a mudanças e não como um padrão de comportamento definitivo. Tal visão diminui a chance desses adolescentes virem a ser precocemente classificados como portadores de parafilias (Hunter, 2012a; Ryan, 2012) e contribui para elencar medidas de tratamento ajustadas à sua idade (Worling, Bookalam \& Litteljohn, 2012). Assim sendo, é fundamental que se identifique os fatores de risco relacionados à repetição desses eventos, conforme descrito a seguir.

\section{Fatores de risco e avaliação para estimar a reincidência}

Fatores de risco referem-se a variáveis individuais e contextuais que tornam pessoas ou grupos mais vulneráveis ao desenvolvimento de desfechos negativos (Dalton, Elias \& Wandersman, 2007). Eles tanto podem ser endógenos, relativos às características de personalidade, às atitudes e aos interesses de um indivíduo, como exógenos, relacionados a eventos, experiências e ao ambiente (Hunter, 2012a). 
Diversos autores têm se debruçado a identificar os fatores de risco associados a repetição de episódios de ofensa sexual (Spice et al., 2012; Worling \& Curwen, 2001) com o intuito de compreender a ocorrência dos eventos. Não há, todavia, unanimidade quanto aos fatores de risco para recidiva em adolescentes. Alguns investigadores apontam a vitimização sexual como preditora para a repetição dos comportamentos (Hunter \& Figueredo, 2000), enquanto outros (Worling \& Langstrom, 2006) a associam ao emprego de armas e ameaças por ocasião do ato ofensivo, ao acesso precoce à pornografia e a delitos não sexuais.

Por isso, a avaliação de risco para a reincidência pode diferir na combinação de fatores e em sua previsão (Hempel, Buck, Cima \& Van-Marle, 2013), bem como basear-se em dados retrospectivos, que se referem a coletas efetuadas em arquivos do sistema de justiça criminal, ou prospectivos, envolvendo informações colhidas diretamente com o jovem, em interações face a face (Worling, Bookalam \& Litteljohn, 2012).

Uma das razões que motivam a necessidade de compreensão dos fatores associados à reincidência é a possibilidade de se estimar o risco do comportamento ocorrer no futuro. A avaliação de risco é um recurso relevante no contexto das decisões judiciais e tem, basicamente, duas finalidades: fazer a previsão da reincidência e estabelecer a necessidade de intervenção (Braga \& Gonçalves, 2011), como em casos de ofensa sexual. No contexto atual, há dois instrumentos que costumam compor os trabalhos investigativos, ambos construídos na primeira década do século XXI: The Juvenile Sex Offender Assessment Protocol-II (J-SOAP-II; Prentky \& Righthand, 2003), e Estimate of Risk of Adolescent Sexual Offense Recidivism (ERASOR; Worling \& Curwen, 2001). O primeiro instrumento é dirigido a adolescentes do sexo masculino, com idades entre 12 e 18 anos e inclui fatores de risco estáticos (que não mudam ao longo do tempo) e dinâmicos (suscetíveis a alterações). De acordo com Prentky e Righthand (2003), o J-SOAP-II foi construído para prever tanto a 
reincidência sexual nessa faixa etária, como a repetição de delitos de outra natureza, sendo esta uma das principais diferenças em relação ao segundo instrumento.

O ERASOR, por sua vez, se destina a adolescentes entre 12 e 18 anos, que cometeram pelo menos uma ofensa sexual, e busca avaliar a possibilidade de recidiva exclusivamente para este tipo de crime. $\mathrm{O}$ instrumento, a ser preenchido por técnicos, se constitui em um checklist e é considerado uma referência na América do Norte (Spice et al. 2012). O ERASOR já está traduzido e validado para a língua portuguesa (Barroso \& Manita, 2012) com autorização de Worling e Curwen (2001), para ser utilizado no contexto lusitano. Worling e Curwen selecionaram 25 fatores de risco, dos quais nove dizem respeito a variáveis estáticas, como a história de vida do sujeito, sua idade, sexo da (s) vítima (s) e o número de denúncias a que ele responde, e 16 variáveis dinâmicas, entre elas o comportamento sexual, o envolvimento com pares desviantes e com influência negativa e o grau de impulsividade. Os fatores de risco estão classificados em cinco itens: (a) interesse sexual, atitudes e comportamentos; (b) histórico de ofensas; (c) funcionamento psicossocial; (d) funcionamento familiar e ambiental; e (e) tratamento. Cabe ressaltar que o ERASOR se constitui em um recurso de avaliação estruturado, que envolve o julgamento clínico quanto ao grau de risco para a recaída, ou seja, baixo, moderado ou alto.

Por outro lado, tais instrumentos ainda precisam adquirir robustez no que tange à validade e à confiabilidade, pois foram construídos recentemente e aplicados em um universo reduzido de participantes (Murrie, 2012). Neste sentido, Worling, Bookalam e Litteljohn (2012) procuraram examinar a validade prospectiva do checklist ERASOR em uma amostra com 191 adolescentes, com o intuito de minimizar os déficits que ainda persistem. Os resultados apontaram que a soma dos fatores de risco, o julgamento clínico efetuado pela equipe de avaliação e as sessões de follow-up mostraram-se significativamente preditivos para a reofensa sexual. 
Estudos com esse propósito, portanto, podem ajudar a compor um quadro mais consistente e credível acerca do tema e dos recursos avaliativos. Acredita-se que, nos próximos anos, investigações sobre prognose de recidiva de ofensa sexual serão ampliadas, sobretudo as que dizem respeito à camada jovem. A seguir são apresentadas algumas estratégias interventivas e a necessidade de democratização destas ações para contextos que ainda não dispõem de um trabalho estruturado.

\section{Da responsabilização à intervenção}

Mais do que identificar e contabilizar os fatores de risco, os profissionais que atuam no campo forense necessitam estimar o grau de tratabilidade do jovem, a fim de traçar um plano de atendimento adequado e eficaz (Braga \& Gonçalves, 2011). Para tanto, é imprescindível a avaliação do indivíduo sob diferentes dimensões como, por exemplo, suas relações interpessoais, as questões intrapsíquicas, as contextuais e o suporte oferecido pela rede social de apoio (Worling \& Curwen, 2001).

Em paralelo à referida avaliação, é comum ocorrer a instauração do processo legal e o confronto do autor da violência com o sistema de justiça, cuja prioridade, de acordo com Ryan (2012), está centrada na punição, em detrimento à reabilitação e às políticas interventivas. Esta postura tem aumentado, apesar de se saber que a ênfase no aspecto punitivo é um dos maiores obstáculos ao processo de ressocialização do adolescente e pouco colabora no cultivo a atitudes positivas. Baseia-se na ideia de que o sujeito deve sofrer pelo que fez (Conceição, 2010), ao invés de ser preparado para enfrentar as adversidades e reparar o dano cometido.

Muito embora o comportamento sexual ofensivo varie em extensão, gravidade, persistência e faixa etária (Hunter, 2012a), é esperado que todo aquele que tenha praticado um ato sexual impróprio seja devidamente responsabilizado e receba o cerceamento da 
sociedade. Na verdade, cada vez mais, os adolescentes e jovens, tanto quanto os adultos acusados deste tipo de conduta, têm provocado repulsa e medo na população (Ryan, 2012) e a resposta aos delitos repercute no recrudescimento das leis (Spice et al., 2012).

O encarceramento na fase inicial da adolescência é uma alternativa usada com frequência em alguns países, cuja justificativa está pautada na proteção ao cidadão (Ryan, 2012), o que não deixa de ser uma decisão extrema e nefasta ao desenvolvimento do indivíduo (Conceição, 2010). De acordo com Hunter (2012b) a elaboração de um plano de atendimento para quem tem problemas de comportamento sexual implica três dimensões: (a) a manutenção da segurança pública; (b) a responsabilização do indivíduo; e (c) a construção de programa especializado, que possa reduzir as chances de reofensa.

Acerca das duas primeiras dimensões, percebe-se que a crença disseminada na repetição das agressões e no discurso da transformação de jovens em futuros "predadores sexuais", sobretudo na sociedade americana, desencadeou medidas mais severas na legislação, como o registro compulsório em um cadastro público para quem comete delito sexual (Spice et al., 2012). O referido modelo tem levado outras nações, a exemplo de Portugal, a cogitar a instauração de norma semelhante em seu território. Entretanto, para Ryan (2012), a falta de respaldo científico quanto à efetividade da medida na diminuição do risco de novos atos acaba por torná-la precipitada, sem legitimidade e sem sustentação empírica.

No que diz respeito ao terceiro aspecto citado por Hunter (2012b), isto é, as ações interventivas, parecem ser as mais promissoras. Jones, Chancey, Lowe e Risler (2010) sustentam que os programas de tratamento para jovens com histórico de agressão sexual variam tanto em estilos de abordagem como de contextos. A maioria segue o modelo cognitivo-comportamental, embora não seja incomum encontrar uma mescla de construtos teóricos embasando os trabalhos; dentre eles os princípios psicodinâmicos. Quanto ao setting 
terapêutico, segundo os autores, há desde programas destinados a estabelecimentos institucionais, com esquema de internação, até ambulatoriais realizados na comunidade e com participação da família e apoio de sua rede social.

Para definir o destino do adolescente e o grau de benefícios que ele poderá desfrutar em um tratamento específico, Hunter (2012b) sugere, primeiramente, estimar o risco de repetição do comportamento indesejável. O jovem, para usufruir dos serviços ambulatoriais, precisa ter um comportamento de baixo risco, sem comprometimento maior do ponto de vista psicológico ou tendências antissociais, bem como ser capaz de reconhecer e assumir seus atos. Grande parte dos jovens, de acordo com o autor, tem condição de ser atendida em programas na comunidade, sob proteção legal. Esse tipo de serviço oferece muitas vantagens em relação à internação, pois o adolescente permanece conectado à sua rotina diária, às funções escolares e perto da sua família, além de ser um custo menor ao Estado.

A investigação de Borduin, Schaeffer e Heiblum (2009) demonstra, porém, que não basta elaborar um plano terapêutico e aplicá-lo aos adolescentes na comunidade, uma vez que o tipo de intervenção faz toda a diferença. Segundo os autores, a Terapia Multisistêmica (MST) tem alta eficácia por estar embasada em princípios ecológicos e abranger o indivíduo, sua família, a escola e membros da sua rede social, cujo foco é reduzir os riscos de reofensa, prevenir novos atos e proteger possíveis vítimas. O estudo com 48 jovens, divididos em dois grupos e submetidos a duas distintas modalidades de intervenção, apontou uma taxa de reincidência de $8 \%$ relativa aos crimes sexuais para aqueles que receberam MST, contra $46 \%$ para os indivíduos tratados com outra abordagem.

A internação em instituição fechada, em contrapartida, requer outro estilo de atendimento e de participação do adolescente. O estudo empreendido por Jones et al. (2010), por exemplo, avaliou a eficácia de um programa em uma instituição com regime de internação para jovens entre 9 e 18 anos de idade, que tinham comportamento sexual 
abusivo. Os autores utilizaram um desenho quase experimental, tipo pré-teste (ingresso) e pós-teste (desinstitucionalização), para detectar mudanças em termos de funcionamento e interesse sexual desviante. A abordagem usada denominou-se multimodal por envolver terapia individual e grupal. Os resultados indicaram que houve um decréscimo significativo quanto ao interesse sexual conjugado à violência e uma melhora em termos comportamentais e emocionais, sugerindo que o programa atinge, preferencialmente, aqueles que apresentam comportamento sexual desviante.

Portanto, há experiências bem-sucedidas e eficazes tanto no ambiente comunitário como em estabelecimentos fechados, mesmo que neste último contexto as adversidades sejam maiores. Worling e Langton (2012) destacam que as instituições com esquema de internação raramente contam com serviços especializados no campo das ofensas sexuais, e os profissionais enfrentam dificuldades para colocar em prática o atendimento. Segundo os autores, os estabelecimentos correcionais costumam ter pouco ou nenhum espaço de privacidade e sigilo, colocando em risco a finalidade da proposta e os resultados almejados.

Ademais, a desconsideração a cuidados éticos mínimos pode gerar um clima de insegurança e discriminações. A simples possibilidade de um jovem ser suspeito de agressão sexual já o torna alvo de preconceitos (Ward, Gannon \& Birgden, 2007) e até de violência perpetrada por outros indivíduos em situação semelhante (Conceição, 2010). Dessa forma, a função do atendimento individual em ambientes com privação de liberdade é, entre outras, preparar a pessoa para um futuro tratamento ambulatorial (Worling \& Langton, 2012).

A intervenção oferecida extramuros constitui uma alternativa viável e acessível. Pessoas significativas do mundo do adolescente podem ser integradas ao atendimento, assim como seus familiares. A meta é ajudar o sistema familiar a lidar com a crise relacionada à descoberta do abuso, ao processo avaliativo, às etapas de acompanhamento e planejamento relativos ao futuro (Worley et al., 2012). Na visão de Costa et al. (2012), incluir pessoas da 
família no tratamento é importante para evitar a reincidência, pois incentiva o comprometimento do jovem com o processo terapêutico e previne a violência transgeracional.

A seguir são apresentados aspectos quanto à legislação e aos serviços interventivos para jovens e adolescentes que cometem ofensas sexuais em dois países, de diferentes continentes: Portugal, que pertence ao continente europeu, e Brasil, um país latinoamericano.

\section{Panorama Português}

Em Portugal, ao longo da última década, cresceu o interesse jurídico e acadêmico sobre pessoas que comentem crimes sexuais. Desde então, investigações acerca da prática de violação, abuso sexual infantil, exploração e coerção sexual têm aumentado e favorecido a capacitação de profissionais nessa área (Barroso, Leite, Manita \& Nobre, 2011). Em duas instituições de ensino do país, por exemplo, na Universidade do Porto e na Universidade do Minho, vários estudos estão sendo desenvolvidos em nível de graduação e pós-graduação, envolvendo vítimas e perpetradores (Barroso et al., 2011).

Quanto à Universidade do Minho, em particular, é importante salientar que o estabelecimento já dispõe de um programa dirigido a atender pessoas adultas e jovens que apresentam comportamento sexual ofensivo. O serviço está disponível na Unidade de Psicologia da Justiça e tem atraído a atenção de tribunais de diversas partes do país com o objetivo de realizar avaliações e ações interventivas para essa parcela da população (Braga \& Gonçalves, 2011).

O trabalho efetuado por Barroso (2012), contudo, demonstra a necessidade de novas ações e de medidas preventivas. Segundo o autor, um quarto de todas as violações sentenciadas pelos tribunais portugueses no ano de 2009 foram perpetradas por jovens com 
menos de 18 anos de idade e, em 2010, os crimes de abuso sexual de crianças representaram 13\%. Quanto às condenações em relação a este último tipo de crime, houve um aumento expressivo em cinco anos, sendo 13 condenações registradas em 2005; 22, em 2008; 24, em 2009; e 31, durante o ano de 2010. O autor reconhece, ainda, que os dados podem conter informações imprecisas decorrentes das "cifras negras", cujas agressões são subnotificadas e deixam de ser integradas às estatísticas. Em outras palavras, os números representam somente uma parte dos episódios e não sua totalidade.

No que diz respeito à legislação relativa aos adolescentes, a Lei Tutelar Educativa (n. ${ }^{\circ}$ 166/99) se dirige a pessoas com idades entre 12 e 16 anos, que praticam fatos categorizados como crime (Braga \& Gonçalves, 2011), a exemplo do que ocorre com delitos de natureza sexual. Do ponto de vista legal, em contrapartida, o jovem com menos de 16 anos ainda não tem suficiente capacidade de entendimento e discernimento sobre seus atos, o que caracteriza, nos termos do disposto no artigo $19 .^{\circ}$ do Código Penal, a inimputabilidade penal. De acordo com Barroso (2012, p. 16), somente a partir dos 16 anos "é que o ordenamento jurídico entende existir a capacidade de determinada pessoa constatar que praticou certos fatos, qualificados pela lei penal como crime, de discernir o que fez (ou está a fazer) ... ". E é com base nesse entendimento que será ou não legalmente punida.

Assim, ao praticar um crime, o adolescente menor de 16 anos encontra-se sob as diretrizes da Lei Tutelar Educativa, cujas medidas tutelares compreendem desde as não institucionais ou na comunidade até a institucionalização em um Centro Educativo. A depender da gravidade do ato, a institucionalização é a mais rigorosa delas e poderá ocorrer em regime fechado, semiaberto ou aberto. O jovem que tem mais de 16 anos, por sua vez, se enquadra no regime especial dos jovens adultos até os 21 anos, e é encaminhado a um estabelecimento prisional. Conforme aponta Barroso (2012), a legislação portuguesa prevê, 
assim, um tratamento diferenciado em função da criança ou do jovem ter 12, 16 ou 21 anos de idade.

\section{Panorama Brasileiro}

A Lei 8.069, chamada de Estatuto da Criança e do Adolescente (ECA), está em vigor desde 1990 e é o instrumento legal que estabelece as medidas socioeducativas a indivíduos entre 12 e 18 anos de idade, que cometem ato infracional e cuja ação equipara-se a toda conduta definida como crime ou contravenção pelo Código Penal do país. O ECA foi construído com base em princípios pedagógicos e éticos centrados na reinserção do adolescente em diferentes âmbitos e na garantia de sua proteção integral. Essa lei tanto tem a função de preservar crianças e adolescentes de qualquer forma de violência, negligência e desrespeito à sua integridade física e emocional, como também de estabelecer medidas socioeducativas, em casos de prática de ato infracional.

O adolescente a partir dos 12 anos de idade está, portanto, sujeito à responsabilização pela infração cometida, cabendo à autoridade competente determinar a mais adequada (Brasil, 1990). As medidas socioeducativas são aplicadas levando em conta que o jovem está em um momento peculiar de desenvolvimento, devendo ser compatíveis à sua capacidade de cumpri-las, às circunstâncias envolvidas no ato e à gravidade da infração. No Estatuto, elas estão organizadas da mais branda à mais rigorosa, conforme segue: advertência, obrigação de reparar o dano, prestação de serviços à comunidade, liberdade assistida, regime de semiliberdade e a privação de liberdade ou internação (Brasil, 1990).

Para além disso, o adolescente pode receber uma medida protetiva e de caráter compulsório, e ser incluído em um programa destinado a atendimento psicológico ou psiquiátrico, em ambiente ambulatorial ou hospitalar. A execução da medida ocorre, 
geralmente, em um contexto destinado a acolher não apenas o adolescente, mas também seus familiares ou responsáveis.

Contudo, em casos de agressão sexual cometida pelo adolescente, poucos são os espaços destinados a esse fim. A realidade brasileira, no que tange à infraestrutura na área de saúde mental, é ainda deficitária, sendo que uma das poucas localidades que dispõe de um trabalho consistente para receber tal demanda é o Distrito Federal, cujo programa de atendimento está em vigor na rede pública desde 2009 (Costa, Junqueira, Meneses, Stroher \& Moura, 2012). Ademais, quando há serviços destinados à população infanto-juvenil que envolve situação de violência, na maior parte das vezes, os profissionais estão capacitados a atender as vítimas de agressão sexual, e não aqueles que a praticam (Bianchini \& De Antoni, 2012).

Ao contrário de outras nações, no Brasil, os jovens que cometem ofensas sexuais também não são incluídos em estudos sobre o tema do abuso sexual e pouco se conhece acerca deles (Pincolini \& Hutz, 2014). As denúncias que constam nos institutos de pesquisa e nos estabelecimentos de saúde se referem a informações genéricas e não mencionam aspectos sociodemográficos dos perpetradores dos episódios (Costa, 2012), o que prejudica a visão geral do problema. Com base nesta constatação, o Conselho Nacional de Justiça CNJ (2012) realizou uma investigação, intitulada Execução das Medidas Socioeducativas de Internação: Programa Justiça ao Jovem em que um dos objetivos foi caracterizar a população adolescente em cumprimento de medida socioeducativa de privação de liberdade, no contexto brasileiro.

A equipe de investigação (CNJ, 2012) entrevistou 1898 adolescentes e coletou dados de 14613 processos judiciais em tramitação nos 26 estados da Federação e no Distrito Federal. Segundo a pesquisa, grande parte dos adolescentes brasileiros, cerca de 47, 5\%, 
tinha entre 15 e 17 anos de idade quando cometeu o primeiro ato infracional, o que corrobora dados da literatura internacional (Farrington et al., 2008).

No que se refere às infrações registradas nos processos, $52 \%$ dizem respeito a atos praticados contra o patrimônio, como roubo, extorsão e latrocínio, enquanto os atos infracionais relativos à prática de abuso sexual são minoria. De acordo com o levantamento, $1 \%$ do total de internações de adolescentes ocorrem em decorrência de estupro (violação), o que pode ser considerado baixo quando comparado ao contexto americano. No estado da Califórnia, por exemplo, o número de jovens presos pelo mesmo crime é 11 vezes maior (Ryan, 2012). Tal informação sugere algumas hipóteses; a primeira seria a falta de denúncias no território brasileiro sobre os episódios sexuais ofensivos perpetrados por jovens (Costa et al., 2012; Pincolini \& Hutz, 2014) ou, em direção oposta, o excesso de encarceramento nos Estados Unidos (Ryan; Spice et al., 2012), ao invés de medidas preventivas.

Sendo assim, supõe-se que o número de adolescentes em privação de liberdade decorrente deste tipo de infração, no Brasil, constitua apenas uma parcela do total de jovens envolvidos em atos sexuais ofensivos. Somente os casos que ocorrem sob violência ou grave ameaça costumam resultar em internação (Brasil, 1990) e as estatísticas existentes resumemse a esses episódios. Portanto, os dados sobre prevalência são imprecisos, o que dificulta o conhecimento acadêmico e científico a respeito do assunto.

\section{Considerações finais}

O fenômeno da ofensa sexual sob a perspectiva do perpetrador é um tema a ser explorado, particularmente, no que diz respeito a adolescentes (Worling \& Langström, 2003), tanto no contexto português (Barroso, 2012; Braga \& Gonçalves, 2011) como no brasileiro (Costa et al., 2012; Pincolini \& Hutz, 2014). A heterogeneidade do comportamento sexual ofensivo demonstra que não há uma forma única e eficiente de tratamento (Hunter, 
2012b; Ryan, 2012); ao contrário, a abordagem deve ser adequada a cada indivíduo e compatível ao contexto (Spice et al., 2012). Dito de outra forma, as intervenções precisam ser distintas para pessoas e contextos distintos, sob o risco de acarretar efeitos iatrogênicos aos adolescentes com conduta menos comprometida quando equiparados a jovens com traços antissociais ou envolvidos em outras infrações (Worling \& Langton, 2012).

As instituições, por sua vez, devem contar com uma equipe capacitada para lidar com o público adolescente sob a temática da sexualidade (Worling \& Langton, 2012). Recolher o indivíduo em um estabelecimento correcional pode ser pertinente em alguns casos, mas não na maior parte deles. No Brasil, por exemplo, o descaso e o desrespeito aos direitos humanos por parte do Estado têm demonstrado o descompasso que vigora entre as diretrizes preconizadas pelo Estatuto da Criança e do Adolescente (ECA) e sua plena efetivação (Conceição, 2010).

Acolher adolescentes envolvidos em atos ofensivos de ordem sexual significa tratar e também prevenir (Costa et al. 2012). Oliver (2007) argumenta que uma das medidas para atingir esse objetivo seria, desde cedo, sensibilizar os adultos para detectar sinais que indiquem os riscos desse comportamento ocorrer. O autor destaca que é importante conscientizar meninos e meninas sobre os prejuízos que tais atitudes provocam na vida dos ofensores e das suas vítimas, tanto a médio como longo prazo. Assim, é importante não apenas impedir que a primeira ofensa sexual ocorra, como não permitir que ela volte a se repetir.

É preciso, portanto, investir em pesquisas que possam compreender o fenômeno sob uma perspectiva ampla, sistêmica e relacional (Costa et al, 2012; Worley et al., 2012). Incentivar o planejamento de estudos exploratórios que levem em consideração as peculiaridades e o contexto das ofensas, bem como a diversidade regional e cultural, tanto no território português, quanto no brasileiro.

Outra possibilidade seria de aprimorar a identificação dos fatores de risco para a reincidência por meio de instrumentos, como questionários, entrevistas e checklists, no 
sentido de conhecer quais são os adolescentes mais vulneráveis, suas especificidades e que medidas podem ser adotadas para ajudá-los a não reincidir (Hempel et al., 2013). Estudos qualitativos poderiam, ainda, auxiliar a detectar os aspectos motivadores para o ato sexual ofensivo e facilitariam a elaboração de programas de atendimento de cunho terapêutico, para além da criminalização e da punição (Pincolini \& Hutz, 2014).

Atuar contra a reincidência, construir programas de intervenção e criar oportunidades para os jovens se desenvolverem de maneira saudável são tarefas primordiais para prospectar uma sociedade menos violenta e mais promissora. $\mathrm{O}$ adolescente, seja ele de que nacionalidade for, precisa ser responsabilizado pelos atos cometidos, tanto quanto ser protegido, respeitado e ter assegurado seus direitos de cidadão. A repressão é uma forma de lidar com os problemas de comportamento, como as ofensas sexuais, não sendo, entretanto, o modo mais eficaz. A parceria entre as instâncias de justiça, o sistema de saúde, os profissionais que atuam na área e as políticas públicas podem dar melhores respostas à sociedade e, em especial, ao jovem e ao adolescente, mediante o uso de instrumentos e atenção adequada aos envolvidos, conforme constatado no estudo qualitativo relatado a seguir. 


\section{MÉTODO}

\section{Pesquisa Qualitativa}

A presente pesquisa se caracteriza pela utilização da metodologia qualitativa, sendo que um de seus fundamentos é a aproximação e o diálogo com o real (Denzin \& Lincoln, 2011). Como processo de produção de conhecimento de natureza qualitativa, toda construção é um modo de acesso à realidade e é compreendida por Demo (2004) como geração de conhecimento e instrumento de ação social. Os processos de convivência e participação mostram a qualidade política, ética do indivíduo e o fazem sujeito de direito. A pesquisa qualitativa envolve o estudo de uma variedade de material empírico, como estudo de caso, narrativas, experiência pessoal, introspecção, história de vida, entrevistas, artefatos, textos culturais e produções (Denzin \& Lincoln, 2011), sendo capaz de incorporar a questão do significado e da intencionalidade como inerentes aos atos, às relações e às estruturas sociais (Bardin, 1977).

\section{O Contexto Institucional}

O contexto mais amplo no qual ocorreu a pesquisa foi o Centro de Orientação Médico Psicopedagógica (COMPP) - Unidade de Saúde Mental Infanto-juvenil - que compõe a Rede de Proteção a Crianças e Adolescentes do Distrito Federal. O COMPP está situado na região central de Brasília e presta atendimento multi e interdisciplinar a crianças e adolescentes entre zero e 18 anos incompletos, procedentes do DF e Entorno (SESDF, 2015). Essa demanda se origina de Conselhos Tutelares, da Delegacia de Proteção à Criança e ao Adolescente - DPCA, da Vara da Infância e Juventude - VIJ, do Centro de Referência Especializado em Assistência Social - CREAS, de ONGs, Abrigos e da Rede de Serviços 
Públicos, dentre outros (Costa et al., 2011).

O COMPP funciona de segunda a sexta-feira em regime ambulatorial e conta com especialistas nas áreas de: Assistência Social, Enfermagem, Fonoaudiologia, Nutrição, Neuropediatria, Neurologia, Pediatria, Psicologia e Psiquiatria. Além destes atendimentos, a Unidade desenvolve projetos como o Programa de Atendimento e Prevenção à Violência (PAV), dirigido a crianças e adolescentes em situação de vulnerabilidade social, maus-tratos, negligência e abuso sexual (SESDF, 2015). Especificamente sobre situações de abuso sexual, há dois grupos distintos de atendimento: um para vítimas e outro para autores de ofensa sexual (entre 12 e 18 anos de idade), ambos na modalidade de Grupo Multifamiliar (GM).

\section{Descrição do Grupo Multifamiliar (GM)}

O objetivo principal deste Programa é ajudar a família a encontrar recursos para lidar com a situação de violência sexual, evitar a repetição das agressões e minimizar as consequências negativas dos episódios. Segundo Costa et al. (2011), esse tipo de intervenção induz à aprendizagem de formas inéditas de comportamento pela pressão ou aprovação do grupo, cujas mudanças ocorrem via semelhança e identificação. Dito de outro modo, o grupo funciona "por semelhança, quando as famílias presenciam, em outras, seus conflitos, e por identificação, quando pais aprendem com outros pais, mães com outras mães, as soluções já encontradas" (p. 451). As famílias, portanto, servem de modelo e referência umas às outras em um ambiente de troca e aprendizado.

Importante destacar que o Grupo Multifamiliar (GM) não é uma iniciativa nova, mas é originário da Terapia Familiar Múltipla que, na década de 50, se direcionava a famílias de pacientes psicóticos (Costa et al., 2011). Costa, Almeida, Ribeiro e Penso (2009) adaptaram tal abordagem para ser utilizada como intervenção psicossocial com famílias em situação de 
violência sexual.

O GM geralmente contempla 5 encontros (etapas). Cada um deles diz respeito a um tema ou conteúdo que deve ser trabalhado pela equipe junto aos participantes do grupo. $\mathrm{O}$ primeiro é o da proteção, isto é, "Devo proteger outras crianças, mas ainda preciso de proteção". O segundo aborda a sexualidade: "Este é o tempo da sexualidade desabrochar". O terceiro se refere à violência sexual: "Violência sexual é crime". O quarto fala da transgeracionalidade relativa à violência: "Precisamos conhecer nossos antepassados" e o último, trata do projeto de namoro: “Ainda quero namorar muito”. De acordo com Costa et al. (2009), os temas foram construídos com base na experiência das autoras e buscam abarcar assuntos relevantes para a reinserção sociofamiliar do adolescente e de sua família no meio comunitário.

A equipe responsável pela atividade do GM no COMPP é formada por cerca de cinco profissionais - psicólogas e assistentes sociais - com especialização, em sua maioria, em Terapia Familiar Sistêmica. Essa equipe coordena as sessões do GM, cujo trabalho é supervisionado por um membro externo, pertencente à academia, que se dedica a realizar pesquisas na instituição. Os trabalhos sobre o tema do abuso sexual tiveram início em 2009 e, desde então, várias publicações foram feitas decorrentes desses estudos. Os encontros do Grupo Multifamiliar acontecem quinzenalmente e tem duração total de três horas por sessão, sendo cada uma delas dividida em três distintas etapas.

Na primeira sessão, as famílias (pais, mães, adolescentes, cuidadores e membros da família extensa) são recebidas e reunidas em uma mesma sala. Neste momento inicial, o foco do encontro é proporcionar a aproximação e a integração entre os participantes. Para atingir essa meta, é usada uma dinâmica de grupo. Os profissionais se apresentam, assim como todos os integrantes do grupo e, na sequência, a equipe acolhe as famílias explicitando os objetivos do atendimento multifamiliar e as regras de funcionamento da instituição. 
No segundo momento, a equipe se divide e inicia um grupo de trabalho exclusivo para adolescentes e outro para os demais familiares. A proposta visa criar um espaço para o adolescente que, em companhia de seus pares, consegue ter mais autonomia e liberdade na expressão de seus anseios. A abordagem ao adolescente inclui jogos, brincadeiras e dramatizações, a fim de facilitar a troca entre eles e a equipe. São jovens que proveem de famílias que apresentam pouca habilidade para estabelecer conversas e negociações (Penso et al., 2012), o que permite o uso de recursos verbais e não-verbais.

Os familiares adultos, por sua vez, integram outro grupo. Neste ambiente eles têm oportunidade de verbalizar e compartilhar suas experiências com pessoas de sua mesma faixa etária que enfrentam dificuldades semelhantes. As crianças também são recebidas em um espaço adaptado para a sua idade, cujo objetivo é oferecer acolhimento e favorecer uma compreensão sobre o tema.

Ao final e terceiro momento, os participantes são novamente reunidos e convidados a falar sobre suas vivências nos subgrupos. Cada encontro tem um assunto definido pela equipe a ser debatido, que serve para nortear a discussão.

Fluxo do Grupo Multifamiliar. Antes de ter início os encontros do Grupo Multifamiliar (GM) propriamente dito, a equipe do GM agenda uma reunião com o adolescente e sua família. Nesta ocasião, a equipe procura conhecer a família, perceber suas necessidades, motivar a participação desta no GM e identificar a fonte de encaminhamento.

Este dia se destina à aplicação de um instrumento utilizado pela equipe. O instrumento, denominado de entrevista de acolhimento, engloba perguntas acerca da dinâmica e composição da família, o genograma familiar e dados sociodemográficos (Costa, et al., 2014). Os profissionais conversam com os presentes sobre o episódio da ofensa sexual que motivou o encaminhamento para o COMPP. Nesse atendimento, o adolescente é 
recebido em conjunto com seus pais ou responsáveis.

Cada sessão com a família dura em torno de duas horas e meia e todas as famílias encaminhadas para o Grupo Multifamiliar são agendadas para o mesmo dia, ou seja, com o intuito de otimizar o tempo, os profissionais se dividem em duplas e atendem simultaneamente. Por fim, é explicado a cada uma delas os objetivos, o funcionamento e a data do primeiro encontro do GM.

Foi neste contexto que a doutoranda se inseriu e acompanhou o processo de atendimento às famílias e aos adolescentes. Ela recebeu prévia autorização da equipe para estar presente. Em função do encontro ter ocorrido em uma única manhã, a doutoranda só presenciou o atendimento a duas famílias: de Airton e de Flávio (conforme descrito nos resultados).

Critérios de Inclusão no Grupo Multifamiliar. Os critérios de inclusão dos adolescentes no GM são: ter entre 12 e 18 anos incompletos, ser do sexo masculino, morar em uma região do Distrito Federal ou do Entorno e ser suspeito/acusado (formal ou informalmente) de envolvimento em situações de ofensa sexual com crianças entre zero e 12 anos de idade. As famílias que o COMPP busca atingir são de nível socioeconômico baixo, com renda familiar aproximada de até cinco salários. Algumas estão incluídas em programas de repasse de renda do governo federal, denominado Bolsa Família.

\section{Participantes do Estudo}

Os participantes do estudo foram quatro adolescentes e suas mães/responsáveis encaminhadas ao COMPP. Os nomes dos adolescentes foram substituídos por nomes fictícios, a fim de evitar a identificação dos mesmos. A seguir, são apresentadas três tabelas com informações sobre eles: na Tabela 4, constam as características dos jovens e dados sobre 
o ato sexual ofensivo; na Tabela 5, há a caracterização das famílias; e na Tabela 6, informações sociodemográficas complementares, conforme segue:

\section{Tabela 4}

Características do adolescente e dados sobre o ato sexual ofensivo

\begin{tabular}{cccccccc}
\hline $\begin{array}{c}\text { Adoles- } \\
\text { cente }\end{array}$ & $\begin{array}{c}\text { Idade ao } \\
\text { cometer a } \\
\text { ofensa }\end{array}$ & Escolaridade & $\begin{array}{c}\text { Número } \\
\text { de } \\
\text { vítimas }\end{array}$ & $\begin{array}{c}\text { Idade } \\
\text { da(s) } \\
\text { vítima(s) }\end{array}$ & $\begin{array}{c}\text { Sexo } \\
\text { da(s) } \\
\text { vítima(s) }\end{array}$ & $\begin{array}{c}\text { Relação } \\
\text { com a(s) } \\
\text { vítima(s) }\end{array}$ & $\begin{array}{c}\text { Contexto } \\
\text { do abuso }\end{array}$ \\
\hline Airton & 14 & $2^{\circ}$ ano E.M. & 1 & 8 & $\mathrm{~F}$ & irmã & Intrafamiliar \\
Flávio & 11 & $6^{\circ}$ ano E.F. & 1 & 5 & $\mathrm{~F}$ & vizinha & Intrafamiliar \\
Gaspar & 12 & $7^{\circ}$ ano E.F. & 1 & 7 & $\mathrm{M}$ & primo & Intrafamiliar \\
Léo & 12 & $6^{\circ}$ ano E.F. & 2 & 8 e 3 & $\mathrm{~F}$ & irmãs & Intrafamiliar
\end{tabular}

Nota. E.M: Ensino Médio e E.F: Ensino Fundamental

\section{Tabela 5}

Caracterização das famílias do adolescente que cometeu ato sexual ofensivo

\begin{tabular}{ccccc}
\hline Adolescente & $\begin{array}{c}\text { Composição familiar } \\
\text { (pessoas que moram na } \\
\text { mesma casa/lote do } \\
\text { adolescente) }\end{array}$ & $\begin{array}{c}\text { Pessoa(s) } \\
\text { responsável(eis) } \\
\text { pelo adolescente }\end{array}$ & $\begin{array}{c}\text { Idade } \\
\text { mãe/avó }\end{array}$ & $\begin{array}{c}\text { Idade } \\
\text { pai/ } \\
\text { padrasto }\end{array}$ \\
\hline Airton & mãe, pai, duas irmãs & mãe e pai & 41 & 46 \\
Flávio & mãe e padrasto & mãe e padrasto & 46 & 43 \\
Gaspar & $\begin{array}{c}\text { avó, bisavó, tio, um irmão, duas } \\
\text { irmãs e dois primos } \\
\text { Lãe, padrasto, três irmãs }\end{array}$ & avó materna & 51 & - \\
\hline
\end{tabular}

Nota. O pai biológico de Flávio mora em outro estado e nunca teve contato com o filho. O pai biológico de Léo é falecido. O pai e a mãe de Gaspar não participam de sua criação. 


\section{Tabela 6}

Dados sociodemográficos dos familiares/responsáveis pelo adolescente

\begin{tabular}{|c|c|c|c|c|c|}
\hline Adol. & $\begin{array}{c}\text { Escolaridade } \\
\text { das mãe/avó } \\
\text { responsável } \\
\text { pelo } \\
\text { adolescente }\end{array}$ & $\begin{array}{c}\text { Escolaridade } \\
\text { do pai/padrasto } \\
\text { responsável pelo } \\
\text { adolescente }\end{array}$ & $\begin{array}{c}\text { Profissão da } \\
\text { responsável } \\
\text { pelo } \\
\text { adolescente }\end{array}$ & $\begin{array}{c}\text { Profissão do } \\
\text { responsável } \\
\text { pelo } \\
\text { adolescente }\end{array}$ & $\begin{array}{c}\text { Renda } \\
\text { familiar } \\
\text { na data da } \\
\text { entrevista } \\
\text { (2013) }\end{array}$ \\
\hline Airton & $\begin{array}{l}\text { curso superior } \\
\text { incompleto }\end{array}$ & $\begin{array}{l}\text { ensino médio } \\
\text { completo }\end{array}$ & manicure & carteiro & $4 \mathrm{SM}$ \\
\hline Flávio & $\begin{array}{c}\text { ensino } \\
\text { fundamental } \\
\text { incompleto }\end{array}$ & $\begin{array}{l}\text { ensino } \\
\text { fundamental } \\
\text { incompleto }\end{array}$ & $\begin{array}{l}\text { empregada } \\
\text { doméstica }\end{array}$ & $\begin{array}{l}\text { ajudante de } \\
\text { pedreiro }\end{array}$ & $2 \mathrm{SM}$ \\
\hline Gaspar & $\begin{array}{c}\text { ensino } \\
\text { fundamental } \\
\text { incompleto }\end{array}$ & 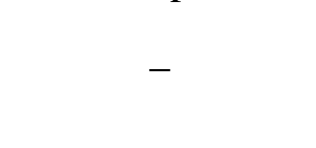 & "do lar" & - & $4 \mathrm{SM}$ \\
\hline Léo & $\begin{array}{l}\text { ensino médio } \\
\text { incompleto }\end{array}$ & $\begin{array}{c}\text { ensino } \\
\text { fundamental } \\
\text { incompleto }\end{array}$ & $\begin{array}{c}\text { auxiliar de } \\
\text { serviços gerais }\end{array}$ & gesseiro & $2,5 \mathrm{SM}$ \\
\hline
\end{tabular}

\section{Instrumentos}

Três instrumentos foram usados na pesquisa e todos foram aplicados pela equipe de profissionais (psicólogas/assistentes sociais) do COMPP. Dois deles - a entrevista semiestruturada (entrevista de acolhimento) e o recurso gráfico (figura) - foram utilizados em um mesmo dia e se destinaram à família e ao adolescente, respectivamente. $\mathrm{O}$ outro instrumento, denominado Checklist ERASOR - Estimativa de Risco de Reincidência de Agressão Sexual em Adolescentes - foi preenchido pelos profissionais, em data posterior.

O primeiro instrumento, denominado "Entrevista de acolhimento para o GM" (Anexo 3), abrangeu dados sociodemográficos, genograma familiar e entrevista semiestruturada. O referido instrumento foi elaborado pela equipe e é utilizado antes dos encontros do Grupo Multifamiliar ter início. Por meio dele, a equipe tem contato com a família e inicia o processo de vinculação dos participantes à instituição. 
O segundo instrumento utilizado foi o ERASOR (Estimate of Risk of Adolescent Sexual Offense Recidivism) (Anexo 4), um checklist elaborado por Worling e Curwen (2001) para servir de apoio a profissionais que buscam estimar o risco de reincidência sexual em indivíduos entre os 12 e os 18 anos de idade que tenham, previamente, cometido delitos sexuais. De acordo com os autores, a diferença de idade entre o adolescente e o indivíduo que sofreu abuso sexual deve ser de pelo menos 4 anos.

O instrumento foi traduzido para o português por Barroso e Manita (2012), em versão autorizada pelos autores para utilização. É composto por 25 fatores de risco, divididos em 5 categorias. Ao final do preenchimento do ERASOR, o avaliador pode estimar o risco global de reincidência: baixo, moderado ou alto. Neste contexto, entende-se reincidência como a prática de um novo ato sexual ofensivo perpetrado pelo adolescente, com ou sem notificação formal.

Os parâmetros gerais elencados por Hunter (2012b) para considerar o risco de reincidência são os seguintes: (a) risco baixo é indicado para comportamentos de natureza não invasiva ou coercitiva, como carícias, por exemplo. Esses atos costumam ser de caráter exploratório e realizados de forma oportunista, sendo que os adolescentes não apresentam traços antissociais, nem evidências de interesses pedofílicos; (b) risco moderado diz respeito ao envolvimento em diferentes tipos de ofensas e conduta mais comprometida, cujos pares e/ou a família têm funcionamento disfuncional. Esses jovens não costumam usar violência e seus interesses são compatíveis a sua idade. É recomendado, para ambos os grupos, tratamento na própria comunidade, embora com diferentes intensidades e objetivos; (c) risco alto abrange atitudes invasivas, com múltiplas vítimas, de longa duração, podendo envolver força e ameaças. Também prevê interesse em pedofilia e preponderância de comportamentos antissociais. Os adolescentes que compõem essa categoria minimizam os atos praticados e 
dificilmente aderem ao tratamento, cuja indicação é de intervenção específica, em unidades de internação, com supervisão 24 horas por dia.

O intuito de utilizar o checklist ERASOR foi qualificar o trabalho dos técnicos que atuam na área de violência sexual na instituição e aumentar o grau de objetividade nas avaliações quanto ao prognóstico de recidiva. Antes de sua utilização, não havia um instrumento específico para a identificação dos fatores de risco. Para colocá-lo em prática, a doutoranda realizou uma reunião com as profissionais antes do GM ter início. Neste encontro, foi disponibilizado material para o grupo sobre o ERASOR, discutido o modo de preenchimento do instrumento e compartilhadas informações sobre o mesmo através de slides. O Erasor está disponível on-line, e faz parte do Programa denominado Sexual Abuse: Family Education \& Treatment (SAFE-T) pertencente a Ontario Ministry of Community \& Social Services, de Toronto, Ontario, Canada.

O terceiro instrumento consistiu na utilização de uma Figura (Anexo 5) escolhida prévia e exclusivamente pela doutoranda, para os adolescentes participantes. Esse recurso foi adicionado ao atendimento da equipe em função da proposta do estudo. Até àquela data, em outras sessões dos Grupos Multifamiliares, o adolescente era visto apenas com sua família e, em nenhum momento, em contexto individual. A doutoranda propôs então a criação de um espaço de escuta para ele com o objetivo de compreender a visão do adolescente sobre si mesmo, em uma perspectiva de futuro. Essa decisão se deve à necessidade de entender o adolescente frente ao processo interventivo e as expectativas quanto à sua própria trajetória. Conforme apontam Zankman e Bonomo (2004), jovens envolvidos em situações de ofensa sexual costumam guardar experiências negativas de seu passado que, por sua vez, influenciam o modo como veem a si próprios e ao seu futuro.

Para compreender tal visão, utilizou-se a figura impressa de uma porta - retirada da World Wide Web - como estímulo à imaginação dos participantes, sob o seguinte enunciado: 
"Imagine que você está diante dessa porta e que você vai atravessar por ela. Quando você fizer isso, vai dar um salto no tempo e você vai se ver daqui a um ano. Como você imagina que estará daqui a um ano? O que terá acontecido com você nesse período? Por gentileza, desenhe elou descreva o que você imaginou”.

Importante destacar que o desenho proposto não teve por objetivo ser analisado e interpretado com base em uma teoria específica. O objetivo principal foi facilitar a expressão verbal dos participantes. No que se refere à perspectiva de futuro, foi escolhido o intervalo de um ano pelo fato de não ser um tempo demasiado longo, mas suficiente para captar as projeções e as possiblidades de mudança antevistas pelos adolescentes.

A inclusão do instrumento buscou facilitar o diálogo entre o adolescente e a equipe, bem como permitir a expressão de suas emoções, desejos e conflitos por meio de um recurso gráfico. Conforme destaca Penn (2002), em pesquisa, o uso de uma figura ou imagem visual é uma forma de comunicação e seu sentido deve estar "ancorado pelo texto que a acompanha" (p.321) não devendo ser interpretada de modo autônomo. Dito de outra maneira, "o texto tira a ambiguidade da imagem (...)" (p. 322) e ajuda a construir um sentido completo para o estímulo.

Além da apresentação da figura, durante o atendimento do adolescente, foram agregadas perguntas sobre sua história pregressa, como: você já sofreu vitimização sexual? Se, sim, quem a cometeu? Que idade você tinha quando isso aconteceu? Essas perguntas não constavam no instrumento (entrevista semiestruturada) dirigido a famílias e, portanto, não eram feitas ao adolescente. Tal lacuna foi identificada durante a elaboração do projeto de pesquisa e, por esta razão, as questões passaram a compor um dos instrumentos.

\section{Etapas da pesquisa e inserção no ambiente institucional}

Conforme descrito anteriormente, a aplicação dos instrumentos da pesquisa ocorreu 
em duas etapas. A primeira delas, que consistiu na aplicação de dois instrumentos, ocorreu em um único dia do mês de setembro de 2013 em uma sala da instituição (COMPP). A equipe era composta por duas profissionais. Neste dia, houve a apresentação da doutoranda e de seu papel à família e foram explanados os objetivos da investigação e solicitado o preenchimento do TCLE.

\section{Limitações institucionais para a realização da pesquisa}

A participação da doutoranda durante o processo limitou-se à observação e a perguntas pontuais, ao final das sessões com o adolescente. A proposta inicial era acompanhar a sessão de atendimento das quatro famílias - selecionadas antecipadamente que fizeram parte do Grupo Multifamiliar (GM). Contudo, a realização simultânea desses atendimentos inviabilizou o plano. A equipe alegou que em virtude de diversos compromissos de trabalho todas as entrevistas deveriam ser feitas em uma mesma manhã. Desta forma, a doutoranda presenciou somente a entrevista de duas famílias e não teve contato concreto com as outras duas. O material de todas as sessões foi gravado em áudio pela equipe e compartilhado. Depois, passou pelo processo de transcrição na íntegra. Também foi vedada a participação da doutoranda no Grupo Multifamiliar, de modo que as observações que seriam feitas neste contexto não foram realizadas. Por esta razão, não foi possível acompanhar a evolução das famílias no GM e, tampouco, colher informações e documentar o que ocorreu no processo interventivo.

A segunda limitação disse respeito aos instrumentos. Havia sido construída uma entrevista bem mais abrangente para ser utilizada separadamente com os adolescentes e com suas mães. O conteúdo da entrevista englobava diferentes tópicos. O primeiro tratava sobre os aspectos circunstanciais e descritivos do episódio ofensivo (Ryan, 2012); o segundo sobre as relações interpessoais e familiares (Braga \& Gonçalves, 2011) e o terceiro dizia respeito 
aos fatores de risco para a prática ofensiva. Além deste instrumento, havia sido construído um questionário sociodemográfico detalhado para complementar as entrevistas. Porém, tal proposta não foi aceita pela equipe. Assim sendo, a pesquisa foi adaptada à realidade da instituição naquele momento, cujo primeiro instrumento que serviu de base para o estudo foi o que estava em uso (entrevista de acolhimento para o GM), conforme descrito anteriormente.

\section{Cuidados Éticos}

O projeto de pesquisa foi submetido e aprovado pela FEPECS - Fundação de Ensino e Pesquisa em Ciências da Saúde sob o número 331/2009-2016. Todos os cuidados éticos foram tomados, conforme estabelece a resolução 466/12 relativa a pesquisas com seres humanos, e o TCLE (Termo de Consentimento Livre e Esclarecido) assinado pelos participantes. As entrevistas foram gravadas em áudio e transcritas na íntegra.

\section{Procedimentos para Análise dos dados}

Para a análise dos dados das entrevistas foi utilizada a Análise de Conteúdo (AC), que consiste, de acordo com Bardin (1977), em "um conjunto de técnicas de análise das comunicações visando obter, por procedimentos sistemáticos e objetivos de descrição do conteúdo das mensagens, indicadores (quantitativos ou não) que permitam a inferência de conhecimentos relativos às condições de produção/recepção (variáveis inferidas) destas mensagens" (p. 42). Neste sentido, as verbalizações dos oito participantes da pesquisa foram gravadas, identificadas e digitalizadas para viabilizar o processo de escuta e transcrição, cujo tempo médio de duração foi de duas horas para cada entrevista. A transcrição foi realizada na íntegra e o tempo médio consumido nesta tarefa foi de, aproximadamente, sete horas por entrevista. 
Em seguida, este material foi submetido a uma categorização, seguindo os passos de construção de sistemas de categorias propostos por Dessen e Cerqueira-Silva (2009). Para a consolidação do sistema final, cerca de três versões preliminares foram construídas. Dois juízes avaliaram a pertinência das categorias e revisaram o material para agregar confiabilidade e credibilidade aos sistemas. Ao final, ambos se mostraram compatíveis aos significados expressos pelos participantes do estudo, bem como aos temas presentes na literatura.

\section{Estágio Sanduíche}

O estágio sanduíche ocorreu entre janeiro e julho de 2015, na Universidade do Minho, em Braga, Portugal. O período de estudos serviu como troca de experiências acerca do tema da tese, cujas atividades foram desenvolvidas na Unidade de Investigação em Justiça e Violência do Departamento de Psicologia Aplicada da Escola de Psicologia da referida Universidade. As atividades foram supervisionadas pela Profa. Dra. Ângela Costa Maia e incluiu a participação da doutoranda em reuniões regulares com a equipe de investigação, reuniões individuais, supervisão de casos, participação na discussão de projeto sobre delinquência juvenil, além da participação em disciplina denominada "Personalidade e Crime”, ministrada pelo professor Dr. Rui Abrunhosa Gonçalves. Durante o período, foi construído um artigo teórico em parceria com a professora Dra. Ângela Costa Maia, denominado "Ofensa sexual perpetrada por adolescentes: Percurso e intervenção no contexto português e brasileiro", que compõe parte da presente tese. 


\section{RESULTADOS}

Os resultados deste estudo estão organizados em três partes. Na primeira parte, há uma breve história dos quatro adolescentes do estudo, onde constam algumas informações sobre a história familiar, as circunstâncias em que ocorreram os episódios ofensivos, as violações vividas pelos adolescentes, as medidas adotadas pelas famílias e as instituições procuradas. Também nesta seção são apresentados os dois sistemas de categorias provenientes das entrevistas com os adolescentes e suas responsáveis, sendo que o Sistema I aborda a ofensa perpetrada pelo adolescente e o Sistema II, o abuso sexual sofrido na infância por dois dos participantes. A segunda parte contém o checklist ERASOR (Estimativa de Risco de Reincidência de Agressão Sexual em Adolescentes). A terceira e última parte apresenta o instrumento de caráter gráfico (uma figura) utilizada para conhecer a perspectiva de futuro dos quatro adolescentes.

\section{Entrevistas: História dos Adolescentes e Sistemas de Categorias}

1. 1. Airton: Entrevista com Airton e sua mãe C. Vítima: I. (irmã, 8 anos de idade)

Breve história familiar: Airton, 16 anos, mora com os pais V. e C. e com suas irmãs A. e I. Airton tem também um irmão mais velho G., de 22 anos, fruto de um primeiro relacionamento de sua mãe. G. já constituiu família e reside com a esposa e dois filhos em uma outra casa. O casal V. e C. vive junto há cerca de 18 anos. Contudo, durante um ano, aproximadamente, o casal ficou separado, época em que ocorreu o episódio ofensivo. Após o fato, V. e C. reataram o relacionamento. Ofensa sexual: Os pais de Airton tomaram conhecimento da ofensa sexual através do Conselho Tutelar. A genitora refere que quando foi chamada na instituição já sabia que algo havia acontecido, mas achava que tudo não tinha passado de uma "brincadeira". A denúncia ao CT foi feita em meio a uma briga entre G. e 
sua irmã A. Depois de G. tê-la agredido fisicamente, a polícia foi acionada e os dois foram encaminhados à delegacia. Neste contexto, G. acusou Airton de cometer ofensa sexual contra a irmã mais nova, I. O episódio ofensivo teria ocorrido, segundo G., na própria residência da família em um momento em que a genitora se encontrava sobrecarregada com a responsabilidade da casa e dos filhos. Nesse período, enquanto a mãe trabalhava, Airton tinha o papel de cuidador de I. Costumava levar e buscar a menina na escola, supervisionar seus afazeres escolares e sua rotina na casa. Após a revelação da ofensa, o pai de Airton retornou à casa da família e reatou a relação com a esposa. A família chegou ao atendimento na instituição (COMPP) dois anos após a ocorrência do ato. Vitimização por abuso sexual: Airton conta que foi abusado por volta dos 5 anos de idade, por um adolescente de 15 anos que frequentava a casa de sua família. Não há informações sobre a frequência do abuso. Segundo ele, o autor das ofensas lhe oferecia doces após o ato sexual. Disse já ter relatado à sua mãe os episódios, mas ela não teria acreditado. Repetição do comportamento: A irmã de Airton I., que foi por ele abusada, repetiu o comportamento/brincadeira com um menino menor e foi flagrada pela mãe.

1. 2. Flávio: Entrevista com Flávio e sua mãe M. Vítima: N. (vizinha, 5 anos de idade). Breve história familiar: Flávio, 12 anos, vive com sua mãe M. e seu padrasto T. Tem três irmãs que não residem com eles. Três meses antes da entrevista, descobriu que tem mais dois irmãos (por parte de pai) e que seu pai biológico, até então desconhecido, vive em outro estado. Flávio diz ter vontade de conhecê-lo e quer viajar para encontrá-lo. A mãe de Flávio refere que sempre se manteve sozinha e cuidou dos filhos sem ajuda de ninguém. Atualmente, porém, tem um relacionamento com T. Ela relata ter sido dependente de álcool e, em determinados períodos da sua vida, o consumia "de segunda a segunda". Em função dos remédios para depressão, diagnosticada recentemente, a ingestão da bebida alcóolica 
ficou reduzida aos finais de semana; o companheiro de M. também faz uso de álcool. Ofensa sexual: Flávio chegou à instituição cerca de 10 meses após ter sido encaminhado à delegacia, em decorrência de denúncia de prática de ofensa sexual contra uma menina. A vítima é sua vizinha e ele seguidamente brinca com a criança e o irmão desta. A acusação partiu da mãe da menina, depois de o filho (também envolvido na situação) contar que Flávio havia colocado "o pinto na perereca da menina". Flávio nega e atribui o ato ao irmão da criança. Vitimização por bullying: Flávio conta situações de bullying vividas na escola e na comunidade em que reside. Diz já ter pensado em se matar quando algumas pessoas debocharam dele e o chamaram de gordo. Já sofreu várias advertências e suspensão na escola por seu mau comportamento e falta de interesse nos estudos. Segundo relato da mãe, ele "é muito agitado e inquieto, não sossega um minuto".

Obs: Em função da proximidade afetiva e geográfica entre a família de Flávio e a família da vítima (vizinha), foi considerado que a situação de ofensa sexual se deu em contexto intrafamiliar, como as demais.

1. 3. Gaspar: Entrevista com Gaspar e a avó materna D. Vítima: P. (primo, 7 anos de idade) Breve história familiar: Os pais de Gaspar, 14 anos, são separados desde que ele tinha um ano de idade. Gaspar tem pouco contato com ambos, sendo que sua mãe tem depressão e o pai não é presente. Ele morou por mais de 10 anos com a avó paterna. Entretanto, em função do seu comportamento indisciplinado, foi entregue à família materna para a avó D. que, por sua vez, é responsável por 6 netos. Ofensa sexual: A ofensa sexual perpetrada por Gaspar ocorreu dois anos antes da entrevista na instituição (COMPP) e não foi denunciada a nenhum órgão. Na época, as irmãs de Gaspar presenciaram o ato ofensivo contra o primo - cinco anos mais jovem - e contaram para a avó D. As meninas pediram a ela, avó, que mantivesse silêncio sobre o ocorrido, a fim de preservar Gaspar de uma provável agressão do pai da 
vítima. A busca por atendimento no COMPP foi motivada pela vulnerabilidade e pelas situações de risco vivenciadas por P. e sua irmã M., tendo em vista que o casal de irmãos vivia exposto à negligência, ao abandono e à violência. Além disso, P. já havia sofrido um primeiro abuso sexual, ocasião na qual sua mãe estava presa. Em decorrência destes acontecimentos, P. e sua irmã passaram a morar com a avó D. e a conviver com outros quatro netos; dentre eles, Gaspar. Vitimização por abandono e rejeição: A mãe de Gaspar nunca conseguiu exercer o papel de mãe e o pai não participa da vida do filho. Ambos o entregaram para ser criado pelos avós (primeiro pelos paternos e atualmente pela avó materna). O menino tem envolvimento em furtos, costuma ficar várias horas do dia em companhia de adolescentes mais velhos, sem supervisão ou controle. Tem baixo rendimento escolar.

1. 4. Léo: Entrevista com Léo e sua mãe R. Vítimas: K. e J. (irmãs de 8 anos e de 3 anos, respectivamente).

Breve história familiar: Léo, 12 anos, mora com sua mãe, o padrasto S. e as irmãs K., J., e M. Tem ainda um irmão, de 9 anos, que desde o nascimento vive com uma tia de sua mãe. Léo e K. são filhos do mesmo pai (E.) que faleceu aos 25 anos de idade, vítima de homicídio, após envolvimento com o tráfico de drogas. Quando Léo nasceu, sua mãe tinha 15 anos de idade e ele foi criado com a ajuda da avó materna e pouco conviveu com o pai. As irmãs J. e M. são filhas de S., atual companheiro da mãe. Ofensa sexual: Léo cometeu ofensa sexual contra sua irmã mais velha K., e depois contra J. Não há informações consistentes quanto à frequência e duração dos episódios. A genitora diz não ter conseguido perceber quando os atos ofensivos começaram e ficou ciente da situação somente após J. tocar no assunto; a menina queixou-se de dor na região pélvica e pediu para o irmão ser castigado. Na ocasião, não foi feita denúncia sobre os atos praticados por Léo contra as irmãs. Porém, durante uma conversa entre Léo e sua mãe, após a descoberta das ofensas, ele revelou que também havia 
sido vítima de violência sexual. Vitimização por abuso sexual: Léo foi abusado por volta dos nove anos de idade, por um adolescente do sexo masculino. Esse adolescente pertencia à sua escola e ambos frequentavam uma escolinha de futebol financiada pelo governo. $\mathrm{O}$ episódio se deu no vestiário da instituição e só foi revelado por Léo após sua mãe confrontálo. Léo relatou que enfrentou ameaças e perseguição por parte do seu agressor para manter silêncio sobre o episódio. Em virtude do abuso sofrido por Léo, a genitora procurou a delegacia e o Conselho Tutelar para fazer a denúncia, motivo pelo qual foram encaminhados ao COMPP. O período entre a descoberta da ofensa e a entrevista nesta instituição foi de 9 meses.

Na próxima tabela, é apresentado um resumo com informações sobre o motivo do encaminhamento ao COMPP, a forma de acesso dos adolescentes e suas famílias à instituição, o intervalo de tempo entre a denúncia e o atendimento, e a idade do adolescente.

\section{Tabela 7}

Motivo do encaminhamento, instituições envolvidas, o tempo entre a denúncia e o atendimento do adolescente e sua idade

\begin{tabular}{|c|c|c|c|c|}
\hline Adolesc. & $\begin{array}{c}\text { Motivo inicial de } \\
\text { encaminhamento da } \\
\text { família } \\
\text { ao COMPP }\end{array}$ & $\begin{array}{c}\text { Instituições } \\
\text { procuradas para a } \\
\text { denúncia do ato } \\
\text { ofensivo }\end{array}$ & $\begin{array}{c}\text { Tempo entre a } \\
\text { ofensa sexual e o } \\
\text { atendimento no } \\
\text { COMPP }\end{array}$ & $\begin{array}{c}\text { Idade do } \\
\text { adolescente } \\
\text { no início do } \\
\text { atendimento }\end{array}$ \\
\hline Airton & $\begin{array}{l}\text { atendimento para o } \\
\text { adolescente }\end{array}$ & Delegacia e CT & 2 anos & 16 \\
\hline Flávio & $\begin{array}{l}\text { atendimento para o } \\
\text { adolescente }\end{array}$ & Delegacia & 10 meses & 12 \\
\hline Gaspar & $\begin{array}{l}\text { atendimento para a } \\
\text { vítima da ofensa }\end{array}$ & $\mathrm{CT}$ & 2 anos & 14 \\
\hline Léo & $\begin{array}{c}\text { atendimento para o } \\
\text { adolescente como } \\
\text { vítima de abuso }\end{array}$ & Delegacia e CT & 9 meses & 12 \\
\hline
\end{tabular}




\section{Sistema de categorias I e II}

$\mathrm{O}$ estudo deu origem a dois sistemas. $\mathrm{O}$ primeiro se denomina "A ofensa sexual praticada pelo adolescente". Este sistema gerou quatro grandes categorias, a saber: (1) Contextos e relações, (2) Repercussões da violência intra e extrafamiliar, (3) A ofensa sexual em si e (4) Consequências do(s) episódio(s) ofensivo(s). Dentro de cada uma destas categorias foram elencadas subcategorias, cujas frases servem para ilustrar a fala dos participantes. O segundo sistema se chama "O abuso sexual sofrido anteriormente pelo autor da ofensa" e também está dividido em categorias, são elas: (1) Reações após a revelação do abuso e (2) Conexão entre o abuso sofrido e a ofensa praticada.

\section{A ofensa sexual praticada pelo adolescente}

\section{Contextos e Relações}

O Conflito Transgeracional foi a primeira subcategoria elencada, cujas verbalizações são: "Eu achava que desde que Gaspar começou a aprontar, ela (mãe de Gaspar) tinha que corrigir.... Ela não quer ser mãe, entendeu? (...) Jogou lá o pacote de batata e disse: Se vira, mãe! (...) Mas ela tem que aprender a ser mãe!" (Avó de Gaspar).

Também foi detectada Violência no Contexto Intrafamiliar, conforme exemplificado: "O padrasto dele não tem muito essa coisa de conversa não, resolve tudo batendo" (Mãe de Flávio); “Ele (padrasto) pega muito no pé dos meninos (...) Ele tem a desvantagem que ele é bruto, parece um cavalo. (Mãe de Léo).

Violência e Insegurança no Contexto Extrafamiliar é a terceira subcategoria: "Bullying, isso acontece na escola e na rua" (Mãe de Flávio); "Mas lá onde eu moro, ultimamente tá sendo tudo ruim. Então eu prefiro que ele fique dentro de casa” (Avó de Gaspar); "Eu acho que dentro de casa ele tá mais seguro” (Mãe de Léo). 


\section{Repercussões da violência intra e extrafamiliar}

Sofrimento do adolescente: "Acho que as pessoas não gostam de mim... elas começam a falar mal... que eu sou gordo (...) Quando falam alguma coisa na rua... dá vontade de se matar... (Flávio).

Sofrimento dos responsáveis pelo adolescente: "Qualquer raiva que eu passo, a vontade que eu tenho é de pegar a pessoa assim... e matar, então tô tomando remédio pra dormir... na minha casa, se eu não tiver o máximo de cuidado, eu saio quebrando tudo que tiver pela minha frente” (Mãe de Flávio).

\section{A Ofensa Sexual em Si}

Quatro subcategorias foram identificadas, sendo que primeira é denominada de Percepção/Interpretação da Ofensa Cometida: "Nós tava brincando... Aí eu subi em cima dele e na hora minha irmã pegou (Gaspar); "Foi uma vez que fiz. Falava: I. vamo brincar, vamos brincar..." (Airton); "Eu entendi assim, que tinha ocorrido uma brincadeira, ocorrido mesmo uma masturbação, entendeu? Mas assim, do ato sexual, eu não pensava! (...) E foi um ato anal!”. (Mãe de Airton); "Eu tava brincando com a K. e com a J. Daí ela (J.) chegou e falou bem assim: Ei Léo, vão bora brincar de mamãe, papai e filhinha. Aí ela ia ser a mãe. Aí nós foi pro quarto.... Só virei ela de traz e coloquei"(Léo).

A segunda subcategoria é chamada de Explicação/Motivo para a Ofensa: “Eu tive vontade de fazer também, aí eu fui e fiz com elas" (Léo); "Eu acho que o que me levou a fazer isso foi quando eu ia pra escola e os meninos ficavam naquela... aí eles ficavam com aqueles vídeos na escola mostrando pornografia, ficavam falando de masturbação, masturbação, até então eu não conhecia isso. Eles ficavam falando que é muito bom, que tinha que fazer, e ficavam mostrando vídeos" (Airton); "Eu tinha muita curiosidade, o que ia sentir enquanto tava fazendo aquilo, aí ia brincar com a I. Aí foi evoluindo, evoluindo... 
até que teve o ato" (Airton); "Porque ele só quer brincar com criança pequena, ele não cresceu ...” (Mãe de Flávio).

A terceira subcategoria é a Atribuição de Culpa pelo Ato Ofensivo, como se observa nas frases: "Foi ela (irmã-vítima) mesma que quis mais..." (Léo); Aí ele (primo-vítima) só mandou nós tirar a roupa, aí eu tirei. Não passou nada” (Gaspar).

A quarta subcategoria é a Responsabilização do Autor pela ofensa: “Eu acho que o Airton não deveria ser, vamos dizer assim, punido, mas corrigido” (Mãe de Airton).

\section{Consequências do Episódio Ofensivo}

Para apresentar esta categoria, optou-se por dividi-la em três níveis de subcategorias, conforme segue. Para as vítimas: Solicitação de limites para o adolescente; Para o autor da ofensa: Medo de ser descoberto; Para a família: (1) Culpabilização, (2) Ambivalência entre conversar e bater e (3) Mudanças positivas. As verbalizações são:

Para as vítimas: Solicitação de limites para o adolescente: "Ela (vítima) não chegou a contar sobre o fato, mas dizia: 'Bate nele, bota ele de castigo' (Mãe de Léo); “Ela falava pra mim: 'Ah mãe, por que você tá fora? Por que você não volta com o pai?' (...) (Mãe de Airton).

Para o autor da ofensa: Medo de ser descoberto: "Eu falava pra I: Não conta, se não minha mãe vai brigar comigo" (Airton).

Para a família: Culpabilização: "Sempre a mãe é culpada... só que nessa história, eu falo assim: Deus, eu não errei. Pelo contrário, fiz as coisas tudo certinha. Claro que a gente erra. Mas, a que mais tentou fazer tudo certinho, fui eu. E ainda aconteceu isso... (Mãe de Airton). Ambivalência entre Conversar e Bater: "Eu fui lá falar pra minha avó, e ela falou que não queria saber. Aí de repente o pessoal queria me bater. Ela ficou um tempo sem vir, sem conversar comigo. Aí depois ela veio" (Gaspar); "Aí todo mundo soube, meu 
pai ficou chorando, queria me bater, mas não me bateu (...)” (Airton). Mudanças positivas: “É que eles se uniram mais (os filhos), se respeitaram mais... Até o meu relacionamento com o V. (marido) hoje, é um relacionamento de mais companheirismo” (Mãe de Airton); “Ele falou que queria conversar sério comigo. De homem pra homem” (Airton).

\section{O abuso sexual sofrido pelo adolescente autor da ofensa}

No II Sistema, foram encontradas duas categorias. A primeira se refere a Reações após a Revelação do Abuso Sexual, que por sua vez, está dividida em subcategorias: Dúvida sobre a Vitimização e Sentimentos/Frustrações. Esta subcategoria está separada em três temas: culpa, revolta e raiva. A segunda categoria é chamada de Ligação entre o Abuso Sofrido e a Ofensa Praticada, como se vê a seguir:

\section{Reações após a Revelação do Abuso Sexual}

Dúvida sobre a Vitimização: “Eu já falei isso (vitimização) pra minha mãe, mas ela não acredita”. (Airton). Descrição dos sentimentos: 1. Culpa: "Eu me senti muito culpada, porque no comportamento dele, eu não percebi a mudança” (Mãe de Léo); 2. Revolta: "Quando eu fiquei sabendo da situação, eu me revoltei porque assim, eu podia ter protegido muito mais ele (filho)...”. (Mãe de Léo); 3. Raiva: “Tenho raiva, ódio” (Léo).

\section{Conexão entre o Abuso Sofrido e a Ofensa Praticada}

Para o autor: "Eu tava assistindo televisão, eu me lembrei (do abuso sofrido), peguei... e fiz nela (Léo); “Aí depois que aconteceu, ela foi brincar com o outro menino... aí minha mãe falou com ela” (Airton). 
Para a família: "A minha preocupação com o que aconteceu lá atrás é que, pelo que eu percebi, e eu posso tá errada, (...) a atitude que ele tomou foi uma reflexão, um... um... assim, foi um reflexo do que aconteceu com ele” (Mãe de Léo). 


\section{Tabela 8}

\section{Sistema de Categorias I e II}

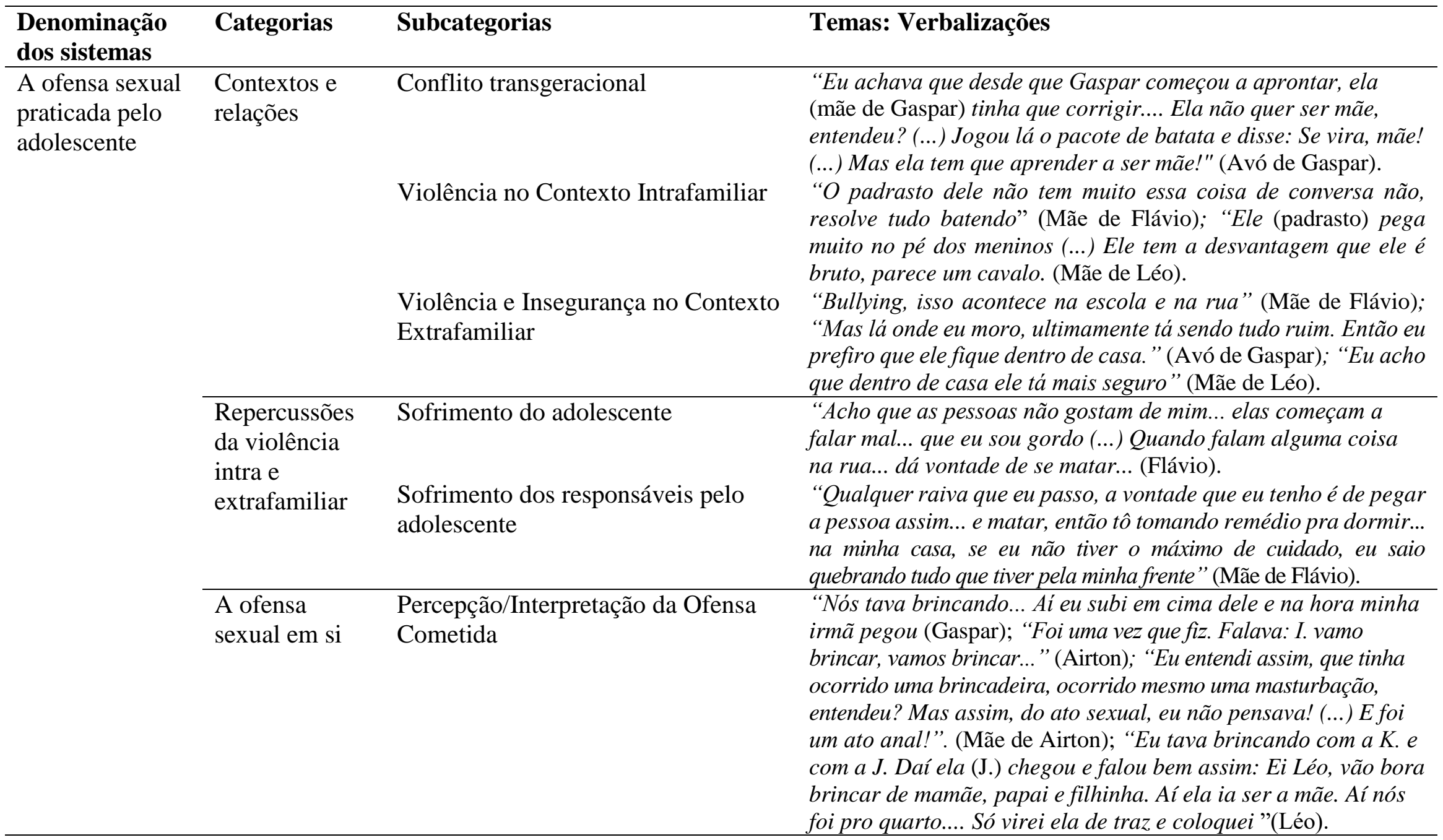




\begin{tabular}{lll}
\hline A ofensa sexual & A ofensa & Explicação/Motivo para a Ofensa \\
praticada pelo & sexual em si & \\
adolescente & (cont.) & \\
(cont.) & &
\end{tabular}

Atribuição de Culpa pelo Ato

Ofensivo

Responsabilização do Autor pela ofensa

Consequências
do(s)
episódio(s)
ofensivo(s)

para o autor da ofensa

para a família
"Eu tive vontade de fazer também, ai eu fui e fiz com elas" (Léo); "Eu acho que o que me levou a fazer isso foi quando eu ía pra escola e os meninos ficavam naquela... aí eles ficavam com aqueles vídeos na escola mostrando pornografia, ficavam falando de masturbação, masturbação, até então eu não conhecia isso. Eles ficavam falando que é muito bom, que tinha que fazer, e ficavam mostrando videos" (Airton); "Eu tinha muita curiosidade, o que ía sentir enquanto tava fazendo aquilo, aí ia brincar com a I. Ai foi evoluindo, evoluindo.. até que teve o ato" (Airton); "Porque ele só quer brincar com criança pequena, ele não cresceu ..." (Mãe de Flávio).

"Foi ela (irmã-vítima) mesma que quis mais..." (Léo); Aí ele (primo-vítima) só mandou nós tirar a roupa, aí eu tirei. Não passou nada" (Gaspar).

"Eu acho que o Airton não deveria ser, vamos dizer assim, punido, mas corrigido" (Mãe de Airton).

solicitação de limites para o adolescente: "Ela (vítima) não chegou a contar sobre o fato, mas dizia: 'Bate nele, bota ele de castigo'. (Mãe de Léo); "Ela falava pra mim: 'Ah mãe, por que você tá fora? Por que você não volta com o pai?' (...) (Mãe de Airton).

Medo de ser descoberto: "Eu falava pra I: Não conta, se não minha mãe vai brigar comigo" (Airton).

Culpabilização: "Sempre a mãe é culpada... só que nessa história, eu falo assim: Deus, eu não errei. Pelo contrário, fiz as coisas tudo certinha. Claro que a gente erra. Mas, a que mais tentou fazer tudo certinho, fui eu. E ainda aconteceu isso... (Mãe de Airton). 


\begin{tabular}{|c|c|c|c|}
\hline $\begin{array}{l}\text { A ofensa sexual } \\
\text { praticada pelo } \\
\text { adolescente } \\
\text { (cont.) }\end{array}$ & $\begin{array}{l}\text { Consequências } \\
\text { do(s) } \\
\text { episódio(s) } \\
\text { ofensivo(s) } \\
\text { (cont.) }\end{array}$ & para a família (cont.) & $\begin{array}{l}\text { Ambivalência entre conversar e bater: "Eu fui lá falar pra } \\
\text { minha avó, e ela falou que não queria saber. Aí de repente o } \\
\text { pessoal queria me bater. Ela ficou um tempo sem vir, sem } \\
\text { conversar comigo. Ai depois ela veio" (Gaspar); "Ai todo } \\
\text { mundo soube, meu pai ficou chorando, queria me bater, mas } \\
\text { não me bateu (...)” (Airton). } \\
\text { Mudanças positivas: “É que eles se uniram mais (os filhos), se } \\
\text { respeitaram mais... Até o meu relacionamento com o V. (marido) } \\
\text { hoje, é um relacionamento de mais companheirismo" (Mãe de } \\
\text { Airton); "Ele falou que queria conversar sério comigo. De } \\
\text { homem pra homem" (Airton). }\end{array}$ \\
\hline \multirow[t]{2}{*}{$\begin{array}{l}\text { O abuso sexual } \\
\text { sofrido } \\
\text { anteriormente } \\
\text { pelo autor da } \\
\text { ofensa }\end{array}$} & $\begin{array}{l}\text { Reações após a } \\
\text { revelação do } \\
\text { abuso }\end{array}$ & $\begin{array}{l}\text { Dúvida sobre a Vitimização } \\
\text { Sentimentos/ } \\
\text { Frustrações }\end{array}$ & $\begin{array}{l}\text { "Eu já falei isso pra minha mãe, mas ela não acredita”. } \\
\text { (Airton). } \\
\text { Culpa: “Eu me senti muito culpada, porque no comportamento } \\
\text { dele, eu não percebi a mudança” (Mãe de Léo) } \\
\text { Revolta: “Quando eu fiquei sabendo da situação, eu me revoltei } \\
\text { porque assim, eu podia ter protegido muito mais ele (filho)...”. } \\
\text { Raiva: "Tenho raiva, ódio" (Léo). }\end{array}$ \\
\hline & $\begin{array}{l}\text { Conexão entre } \\
\text { o abuso sofrido } \\
\text { e a ofensa } \\
\text { praticada }\end{array}$ & Para a família & $\begin{array}{l}\text { "Eu tava assistindo televisão, eu me lembrei (do abuso sofrido), } \\
\text { peguei... e fiz nela (Léo); "Ai depois que aconteceu, ela foi } \\
\text { brincar com o outro menino... aí minha mãe falou com ela" } \\
\text { (Airton). } \\
\text { "A minha preocupação com o que aconteceu lá atrás é que, pelo } \\
\text { que eu percebi, e eu posso tá errada, (...) a atitude que ele tomou } \\
\text { foi uma reflexão, um... um... assim, foi um reflexo do que } \\
\text { aconteceu com ele” (Mãe de Léo). }\end{array}$ \\
\hline
\end{tabular}




\section{Checklist ERASOR}

A1: Airton A2: Flávio A3: Gaspar A4: Léo

\begin{tabular}{|c|c|c|c|c|}
\hline $\begin{array}{c}\text { Fatores de Alto risco de } \\
\text { Reincidência de Agressão } \\
\text { Sexual }\end{array}$ & Presente & $\begin{array}{c}\text { Provável/ } \\
\text { parcialmente } \\
\text { presente }\end{array}$ & Ausente & Desconhecido \\
\hline $\begin{array}{l}\text { 1. Interessses sexuais } \\
\text { desviantes (crianças, violência } \\
\text { ou ambos) }\end{array}$ & A4 & & $\mathrm{A} 1, \mathrm{~A} 2$ & A3 \\
\hline $\begin{array}{l}\text { 2. Interessses sexuais } \\
\text { obsessivos/ preocupação com } \\
\text { pensamentos sexuais }\end{array}$ & $\mathrm{A} 1, \mathrm{~A} 4$ & $\mathrm{~A} 2$ & & A3 \\
\hline $\begin{array}{l}\text { 3. Atitudes que suportem } \\
\text { agressão sexual }\end{array}$ & $\mathrm{A} 3, \mathrm{~A} 4$ & & $\mathrm{~A} 1, \mathrm{~A} 2$ & \\
\hline $\begin{array}{l}\text { 4. Falta de vontade em alterar } \\
\text { interesses e atitudes sexuais } \\
\text { desviantes }\end{array}$ & & & $\begin{array}{l}\text { A1, A2, } \\
\text { A4 }\end{array}$ & A3 \\
\hline \multicolumn{5}{|l|}{ HISTÓRICO DE CRIMES } \\
\hline $\begin{array}{l}\text { 5. Crimes sexuais contra duas } \\
\text { ou mais vítimas }\end{array}$ & A4 & & $\begin{array}{l}\mathrm{A} 2, \mathrm{~A} 3, \\
\mathrm{~A} 1\end{array}$ & \\
\hline $\begin{array}{l}\text { 6. Crime sexual contra a } \\
\text { mesma vítima duas ou mais } \\
\text { vezes }\end{array}$ & $\mathrm{A} 1, \mathrm{~A} 4$ & & & $\mathrm{~A} 2, \mathrm{~A} 3$ \\
\hline $\begin{array}{l}\text { 7. Anterior sanção aplicada por } \\
\text { adultos por crime(s) sexuais }\end{array}$ & & & $\begin{array}{l}\mathrm{A} 1, \mathrm{~A} 2 \\
\mathrm{~A} 3, \mathrm{~A} 4\end{array}$ & \\
\hline $\begin{array}{l}\text { 8. Ameaça de, ou uso de, } \\
\text { violência ou armas durante a } \\
\text { agressão sexual }\end{array}$ & & & $\begin{array}{l}\mathrm{A} 1, \mathrm{~A} 2, \\
\mathrm{~A} 3, \mathrm{~A} 4\end{array}$ & \\
\hline $\begin{array}{l}\text { 9. Crime sexual contra } \\
\text { crianças }\end{array}$ & $\begin{array}{l}\text { A } 1, \text { A2, A3, } \\
\text { A } 4\end{array}$ & & & \\
\hline $\begin{array}{l}\text { 10. Crime sexual contra } \\
\text { desconhecidos }\end{array}$ & & & $\begin{array}{l}\text { A1, A2, } \\
\text { A3, A4 }\end{array}$ & \\
\hline $\begin{array}{l}\text { 11. Escolha indiscrimanda da } \\
\text { vítima }\end{array}$ & & & $\begin{array}{l}\mathrm{A} 1, \mathrm{~A} 2 \\
\mathrm{~A} 3, \mathrm{~A} 4\end{array}$ & \\
\hline $\begin{array}{l}\text { 12. Crime sexual contra vítima } \\
\text { de gênero masculino (cotado } \\
\text { apenas para adolescentes do } \\
\text { gênero masculino) }\end{array}$ & A3 & & $\begin{array}{l}\mathrm{A} 1, \mathrm{~A} 2, \\
\mathrm{~A} 4\end{array}$ & \\
\hline $\begin{array}{l}\text { 13. Comportamentos diversos } \\
\text { de crimes sexuais }\end{array}$ & & & $\mathrm{A} 1, \mathrm{~A} 4$ & $\mathrm{~A} 2, \mathrm{~A} 3$ \\
\hline $\begin{array}{l}\text { FUNCIONAMENTO } \\
\text { PSICOSSOCIAL }\end{array}$ & & & & \\
\hline $\begin{array}{l}\text { 14. Orientação interpessoal } \\
\text { antissocial }\end{array}$ & A3 & & $\mathrm{A} 1, \mathrm{~A} 2, \mathrm{~A} 4$ & \\
\hline $\begin{array}{l}\text { 15. Relações interpessoais } \\
\text { instáveis/isolamento social }\end{array}$ & & $\mathrm{A} 2$ & $\begin{array}{l}\text { A } 1, \text { A3, } \\
\text { A } 4\end{array}$ & \\
\hline
\end{tabular}


Checklist ERASOR (Cont.)

\begin{tabular}{|c|c|c|c|c|}
\hline $\begin{array}{c}\text { Fatores de Alto risco de } \\
\text { Reincidência de Agressão } \\
\text { Sexual }\end{array}$ & Presente & $\begin{array}{c}\text { Provável/ } \\
\text { parcialmente } \\
\text { presente }\end{array}$ & Ausente & Desconhecido \\
\hline $\begin{array}{l}\text { 16. Envolvimento com pares } \\
\text { desviantes e com influência } \\
\text { negativa }\end{array}$ & A3 & $\mathrm{A} 2$ & A4 & A1 \\
\hline 17. Agressão interpessoal & & & $\begin{array}{l}\mathrm{A} 1, \mathrm{~A} 2, \\
\mathrm{~A} 3, \mathrm{~A} 4\end{array}$ & \\
\hline $\begin{array}{l}\text { 18. Recente escalamento de } \\
\text { raiva e sentimentos negativos }\end{array}$ & A2 & A3 & $\mathrm{A} 1, \mathrm{~A} 4$ & \\
\hline $\begin{array}{l}\text { 19. Autorregulação } \\
\text { deficitária dos afetos e } \\
\text { comportamentos (impulsos) }\end{array}$ & $\mathrm{A} 2, \mathrm{~A} 3$ & A4 & A1 & \\
\hline FUNCIONAMENTO & & & & \\
\hline $\begin{array}{l}\text { FAMILIAR/AMBIENTAL } \\
\text { 20. Ambiente familiar } \\
\text { estressante }\end{array}$ & $\mathrm{A} 2, \mathrm{~A} 3, \mathrm{~A} 4$ & A1 & & \\
\hline $\begin{array}{l}\text { 21. Relação progenitores } \\
\text { agressor } \\
\text { problemática/rejeição } \\
\text { parental }\end{array}$ & $\mathrm{A} 2, \mathrm{~A} 3, \mathrm{~A} 4$ & & A1 & \\
\hline $\begin{array}{l}\text { 22. Falta de colaboração } \\
\text { do(s) genitore(s) em } \\
\text { participar na avaliação } \\
\text { específica de agressão sexual }\end{array}$ & $\mathrm{A} 2, \mathrm{~A} 3$ & & A1, A4 & \\
\hline $\begin{array}{l}\text { 23. Fatores ambientais de } \\
\text { risco de reincidência de } \\
\text { agressão sexual }\end{array}$ & $\begin{array}{l}\mathrm{A} 1, \mathrm{~A} 2, \mathrm{~A} 3, \\
\mathrm{~A} 4\end{array}$ & & & \\
\hline $\begin{array}{l}\text { INTERVENÇÃO / } \\
\text { PROGRAMA } \\
\text { TERAPÊUTICO }\end{array}$ & & & & \\
\hline $\begin{array}{l}\text { 24. Inexistência de planos de } \\
\text { tratamento /estratégias }\end{array}$ & $\mathrm{A} 2, \mathrm{~A} 3$ & A4 & & A1 \\
\hline $\begin{array}{l}\text { 25. Programa de terapia } \\
\text { específico para agressão } \\
\text { sexual incompleto }\end{array}$ & & & $\begin{array}{l}\text { A1, A2, } \\
\text { A3, A4 }\end{array}$ & \\
\hline $\begin{array}{l}\text { OUTROS FATORES: } \\
\text { Prévia vitimização sexual }\end{array}$ & A1 e A4 & & & \\
\hline Grau de Risco Global & Baixo & Moderado & Alto & \\
\hline
\end{tabular}




\section{Figura}

1. Airton: "Eu me imaginei com a S. (ex-namorada), que vai dar tudo certo. E vou estar feliz. Vou conseguir vencer isso... que aconteceu. Vou tá bem com meu pai e minha mãe”.

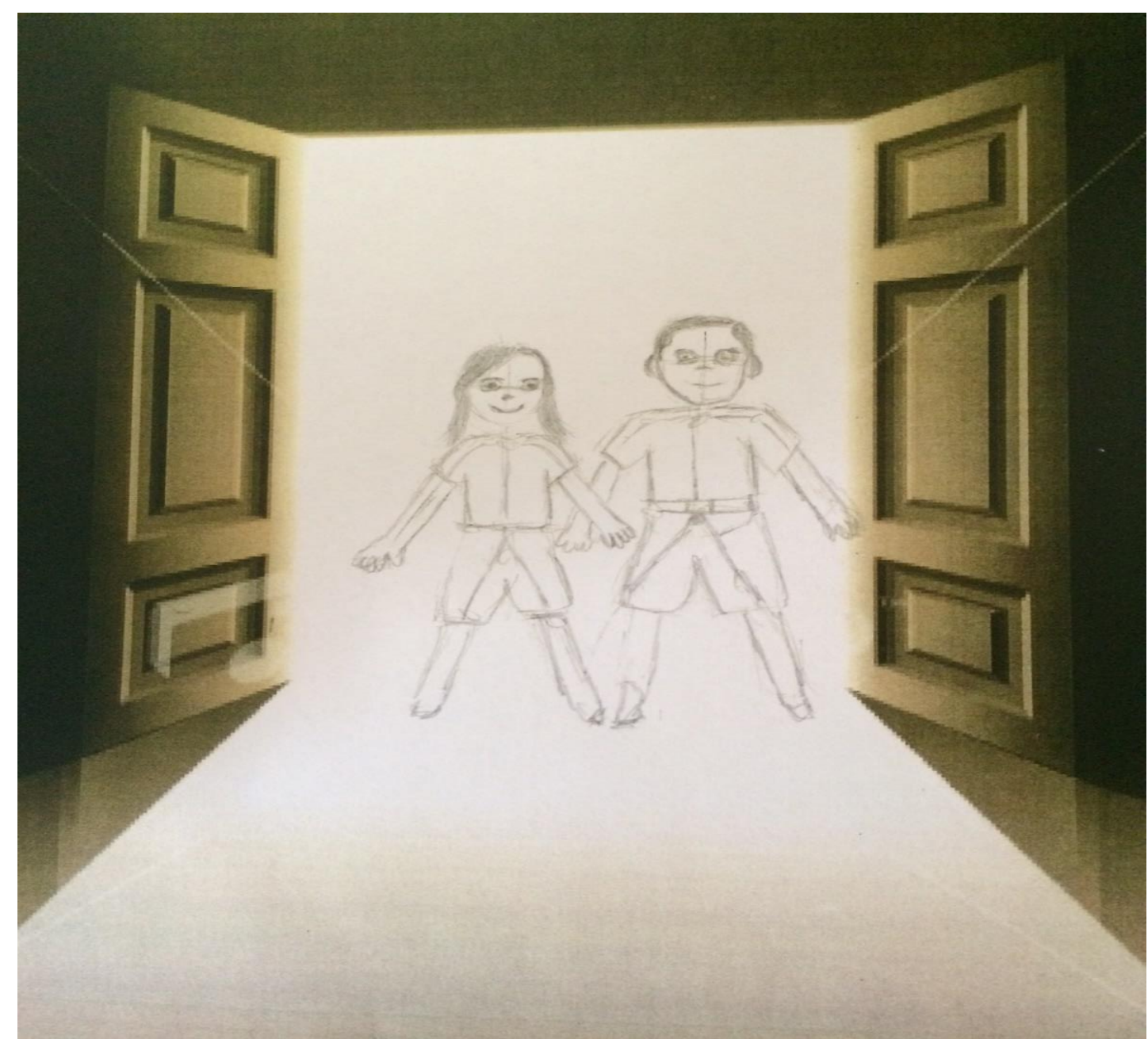


2. Flávio: "Como se eu tivesse saindo do exército, só que de outra forma. Esse carro é uma limusine... trabalhando em outro país, Estados Unidos. Como se eu tivesse saindo de um lugar... como aqui hoje e lá de outro jeito... uma porta aberta pra mim. Eu, salvando o mundo... em guerra”.

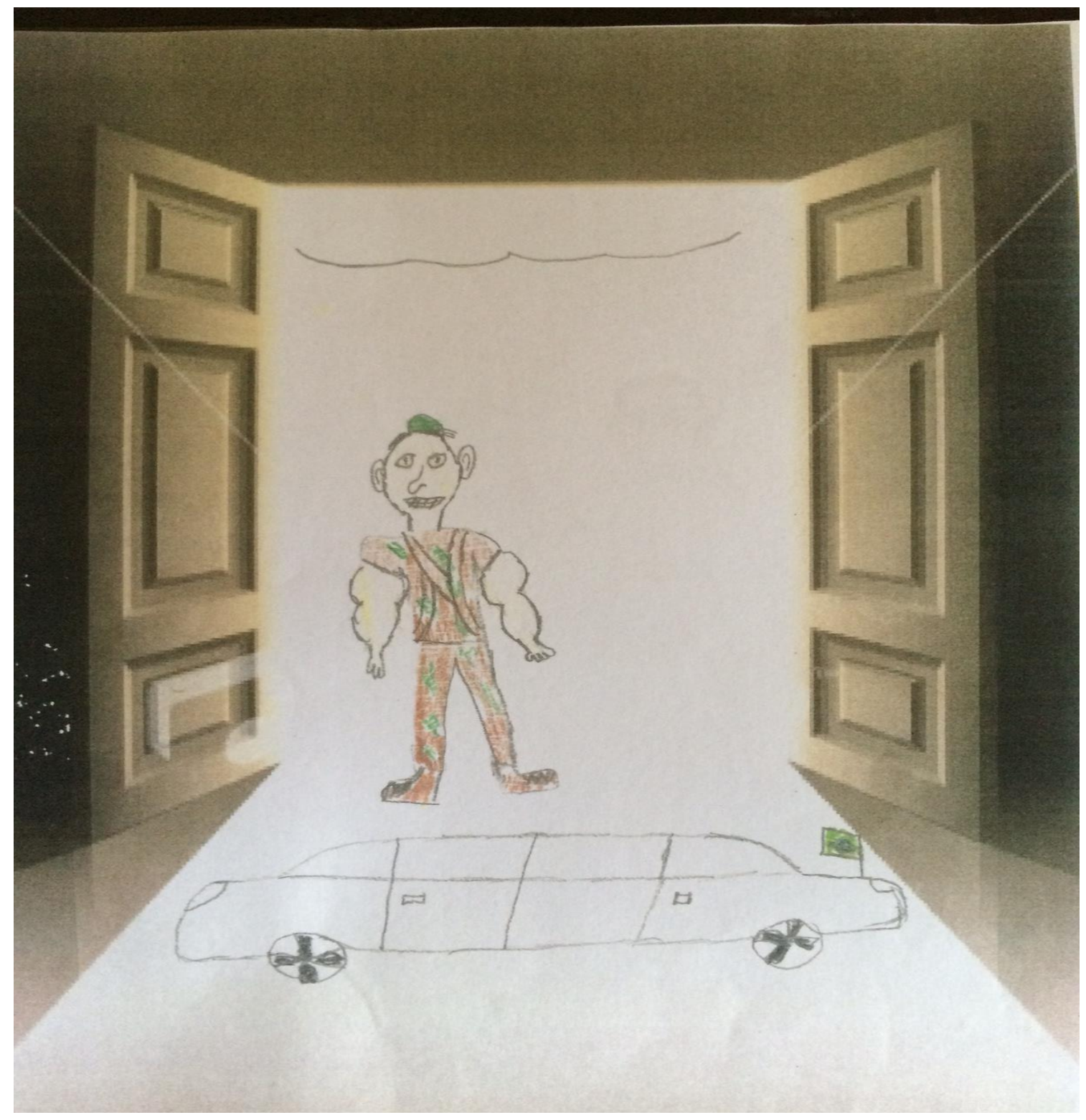


3. Gaspar: "Uma porta aberta e uma luz. Não vou estar mais morando em Taguatinga. Talvez morando em Ceilândia, numa casa. Morando com a avó D. Antes eu não gostava, não. Antes eu tinha тииииииииuita saudade da outra vó. Eu chorava pra voltar. Todo dia eu ia pra lá. Agora não, mas eu sinto saudade dela... Eu vou desenhar eu trabalhando. Não, fazendo alguma coisa: um esporte. Alguma coisa... Porque eu tenho sopro no coração. De vez em quando eu jogo bola no colégio, aí canso rápido. Eu tenho que beber muita água, não posso fazer muito esforço físico”.

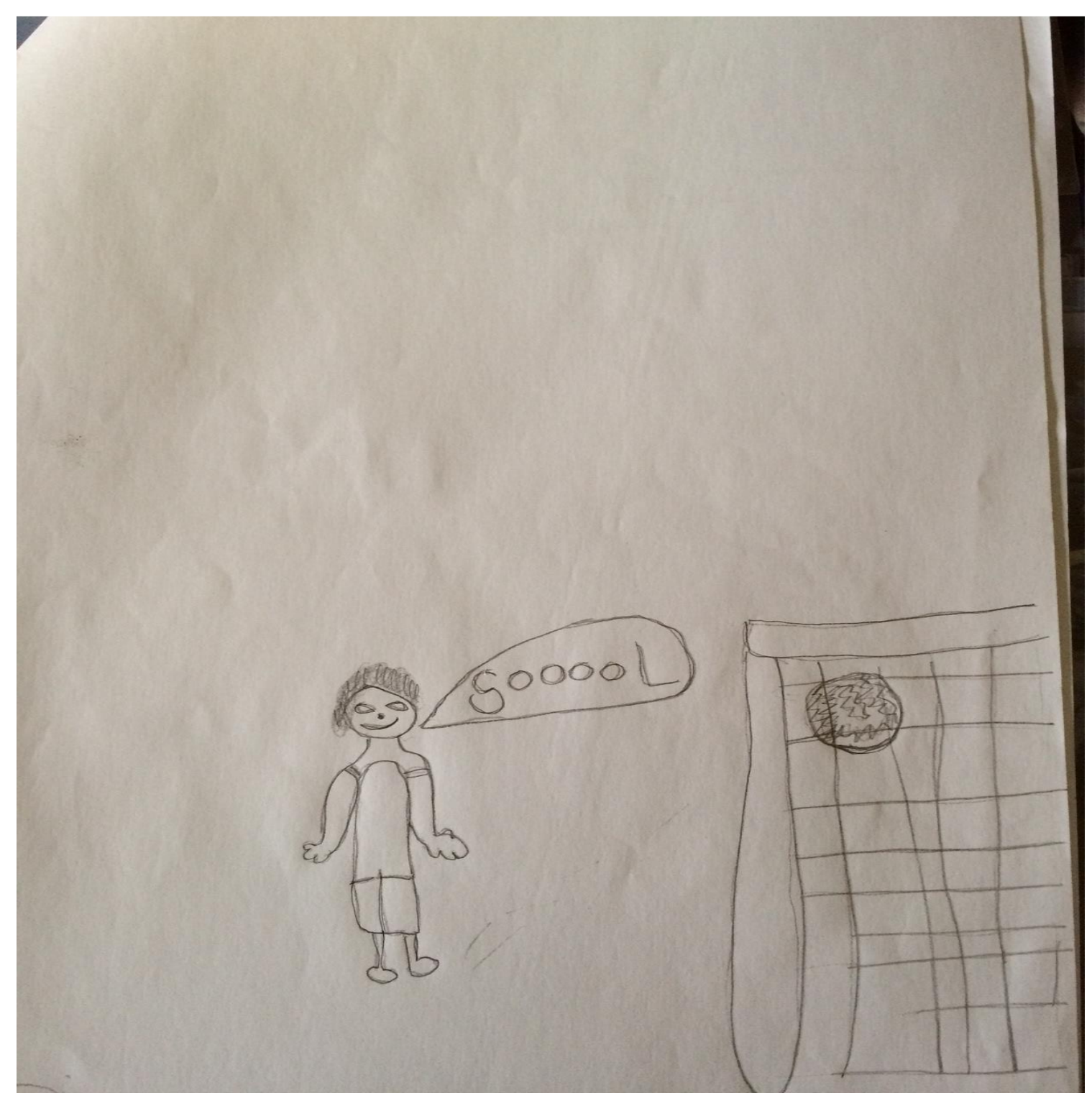


4. Léo: "Uma porta de luz e escuridão. Vai tá mais diferente. As pessoas vão estar mais velhas, muitos vão ter morrido já, e já vão nascer muitas pessoas. Assim... eu seria mais velho, é porque, quando eu crescer, eu quero ser arquiteto porque minha mãe fala que eu desenho muito bem. Aí, como é eu mais velho, é eu entrando em uma escolinha profissional de futebol, pra mim ser jogador de futebol de uma vez, essas coisas assim...”.

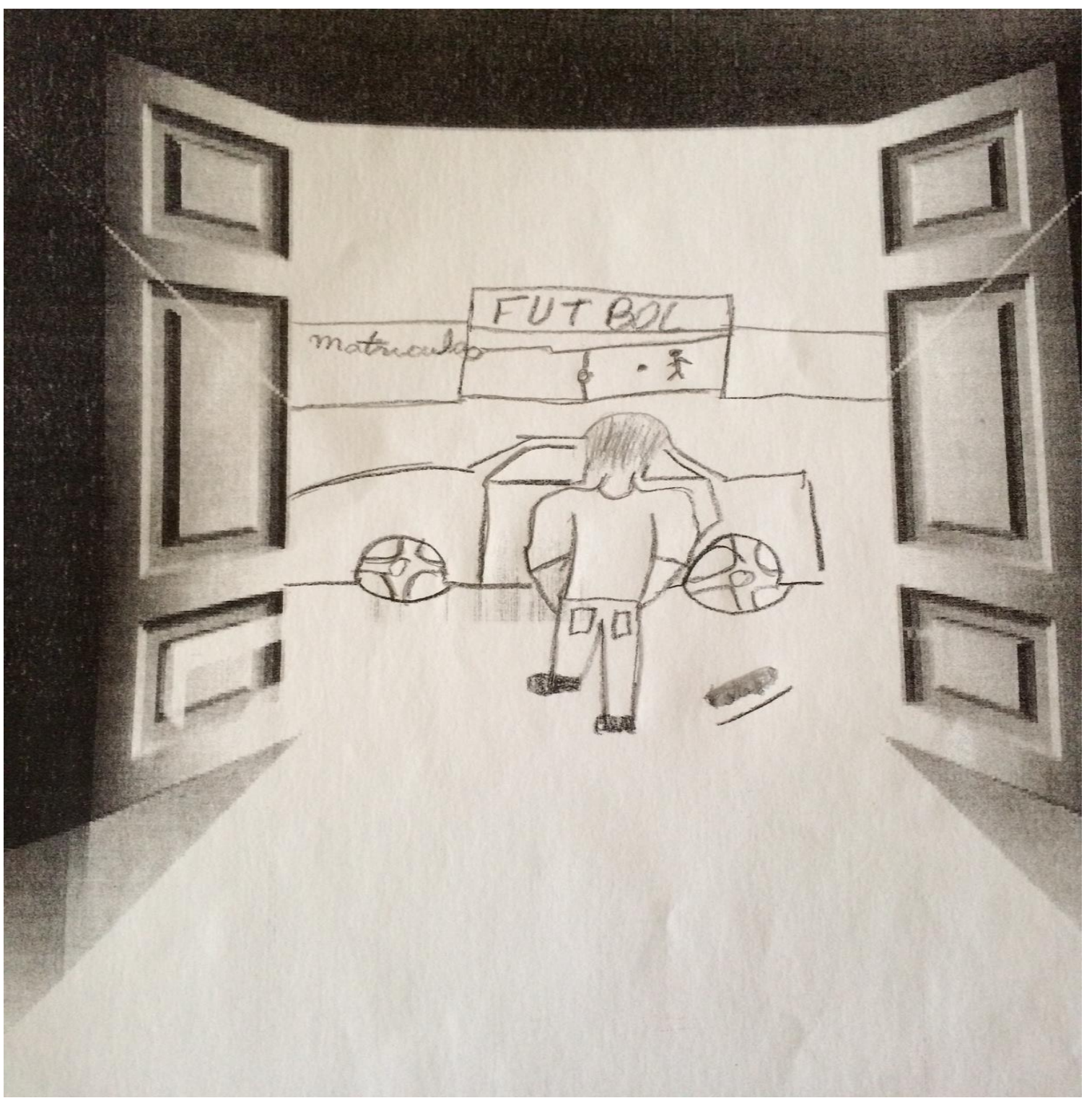




\section{DISCUSSÃO}

Na primeira seção deste capítulo são discutidas todas as categorias e subcategorias relativas à ofensa sexual praticada pelo adolescente, cujos tópicos são: (a) O contexto e as relações que permeiam as situações de ofensa sexual; (b) Pornografia, fantasias e masturbação; (c) Consequências do episódio ofensivo e responsabilização do adolescente; e (d) Mudanças positivas em meio a adversidades. Na segunda seção, são discutidas questões referentes ao abuso sexual sofrido pelo autor da ofensa, com base no item: Conexão entre eventos: abuso e ofensa sexual. A terceira seção trata dos fatores de risco para a reincidência e do ERASOR e, por fim, a quarta seção se refere ao instrumento usado para captar a perspectiva de futuro dos adolescentes.

\section{Discussão dos Resultados 1}

\section{O contexto e as relações que permeiam as situações de ofensa sexual}

A história pregressa dos participantes do estudo, associada aos dados da entrevista, indica que há diversos aspectos convergentes entre o conflito transgeracional, a violência intrafamiliar e a violência extrafamiliar vivenciadas pelos participantes do estudo. Segundo Seto e Lalumière (2010) adolescentes que cometem ofensa sexual apresentam o dobro de relatos sobre abusos físicos vivenciados na infância, quando comparados a adolescentes que se envolveram em outros tipos de delitos. A presença de punição física e de interações familiares emaranhadas são características de um contexto familiar não protetivo (Worley et al., 2012) favorecedor do isolamento social, da hostilidade, da agressividade e de padrões de apego deficitários, frequentemente detectados em adolescentes com comportamento sexual ofensivo (Marshall \& Marshall, 2000). 
Além dos efeitos adversos que esse estilo de parentalidade provoca, há uma forte probabilidade da sua reprodução em contextos futuros. De acordo com Costa e Penso (2014), “cada geração tende a repetir o padrão de relacionamento e a temática de problema da geração anterior” (p.55), conforme se observa nos conflitos entre a avó, a mãe e o adolescente Gaspar, por exemplo. Em outras palavras, ocorre uma atualização dos conflitos não resolvidos, cujo conteúdo foi inadequadamente simbolizado e elaborado (Ramos \& Oliveira, 2008).

Muitas famílias, assim como esta do estudo, não são capazes de fornecer proteção, cuidado e carinho a seus descendentes, mas, ao contrário, constituem um ambiente de risco onde há negligência, desorganização, abandono e rejeição (Costa \& Penso, 2014). É possível notar uma lacuna entre a expectativa da avó em relação à educação do adolescente e a falta de comprometimento da genitora, conforme expresso no seguinte trecho: "Ela não quer ser mãe, entendeu? (...) Jogou lá o pacote de batata e disse: Se vira, mãe!” Se, por um lado, a avó está sobrecarregada de deveres e de responsabilidades para com o neto, por outro, há omissão por parte da mãe e do pai do adolescente, pois nenhum deles assume o papel parental.

A falta de iniciativa para o exercício da paternidade é um obstáculo na criação de limites e regras destinadas ao adolescente e pode servir como um modelo ineficiente de pertencimento e acolhimento. Tal modelo é capaz de perdurar de uma geração para outra se não houver, de fato, uma mudança na dinâmica e nas formas de comunicação entre os membros da família (Costa \& Penso, 2014; Ramos \& Oliveira, 2008). Assim, a normatização do ciclo da violência através das gerações colabora para a prática sexual ofensiva e aumenta a desproteção das vítimas (McCuish et al., 2015).

Para Worley et al. (2012), apesar de a violência doméstica estar presente em diversas famílias de adolescentes que cometem transgressões, naquelas com indivíduos envolvidos 
em situação de ofensa sexual a conjugação entre violência intrafamiliar, práticas parentais equivocadas, ambiente conturbado, depressão, pais afetivamente distantes, uso de drogas ou álcool e padrões de interação problemáticos favorece o surgimento do referido comportamento. Portanto, é nesta complexidade de fatores que o fenômeno da ofensa sexual está inserido e deve ser compreendido (Ryan, 2012; Worley et al., 2012).

Aliada às adversidades do contexto intrafamiliar, estão as dificuldades no ambiente social, como a falta de segurança na comunidade. As famílias deste estudo mencionam outros tipos de violência a que seus adolescentes estão expostos. A prática de bullying, por exemplo, vivenciada dentro e fora da escola, intimida os adolescentes a buscarem espaços de lazer e recreação. Ao invés de experimentarem suas habilidades sociais na interação com outros jovens na rua, eles retraem-se e procuram refúgio dentro de casa (Costa, Marreco, Barros \& Chaves, 2015). Conforme refere Barber-Madden e Saber (2010) são várias pressões micro e macrossociais que a juventude enfrenta, atualmente, e que estão conectadas a novas formas de relação e de organização.

Além disso, no reduto domiciliar, os adolescentes de camadas menos favorecidas da população, como os desse estudo, têm atribuições a serem cumpridas que extrapolam as tarefas escolares. Zelar pelos irmãos menores, levá-los à escola e ajudar nas lições, a exemplo de Airton, são algumas dessas incumbências (Penso et al, 2012). Porém, na contramão à postura de cuidador adotada pelo adolescente, situa-se um outro tipo de interação, denominada por ele e pelos demais participantes da pesquisa, de "brincadeira".

À luz da literatura, a brincadeira relatada pelos jovens é entendida como uma situação de ofensa sexual. Isto porque envolve um adolescente e uma criança na qual a diferença de idade de pelo menos quatro anos (Worling \& Curwen, 2001), a assimetria de poder, o estilo de abordagem e a forma de contato sexual pode ter efeitos deletérios a curto e a longo prazo (Barroso, 2012). Trata-se de um tipo de prática que ocorre sem consentimento, sem 
igualdade de condições e como resultado de uma coerção (ATSA, 2006; Barroso, 2012; Ryan, 2012).

Imbuído em um papel de autoridade e depositário de confiança, o adolescente em situação de ofensa sexual intrafamiliar rompe os limites da atenção e do cuidado que o espaço doméstico deve representar (Penso et. al., 2012). Durante a brincadeira, as fronteiras entre as manifestações sexuais apropriadas à adolescência e as peculiares à infância, se misturam (Murrie, 2012). A pouca distinção entre os dois universos favorece que a referida brincadeira ocorra em um continuum (Ryan, 2012), ou seja, com interações sucessivas e progressivas, antecedentes à situação ofensiva propriamente dita, conforme descreve um dos adolescentes: "Eu tinha muita curiosidade, o que ia sentir enquanto tava fazendo aquilo, aí, ia brincar com a I. Aí foi evoluindo, evoluindo... até que teve o ato” (Airton).

Pelo relato, percebe-se que esse adolescente foi capaz de reconhecer o encadeamento de seus impulsos sexuais mesmo que, naquela ocasião, não tenha encontrado um modo melhor de lidar com eles. O tema da sexualidade, nestas famílias, é considerado tabu e o diálogo entre as gerações não é frequente (Costa et al., 2015), o que dificulta a expressão dos desejos sexuais e favorece a manifestação de comportamentos inadequados (Oliver, 2007). Informações sobre prática masturbatória, prevenção à DSTs e métodos contraceptivos necessitam ser trabalhados junto a essa população. Porém, isolados, não são suficientes para evitar episódios ofensivos.

É preciso estender o debate sobre sexualidade, incluindo não apenas tópicos acerca das mudanças corporais, hormonais e emocionais, como também às relacionais. Auxiliar o jovem a discriminar sexo consentido de sexo forçado, estimular o respeito à sexualidade alheia e a formas de interação não coercitivas são fundamentais. Tais medidas também podem ser úteis para que o adolescente deixe de atribuir a responsabilidade de seus atos à vítima, como se observa na fala de Léo: “Foi ela (irmã) mesma que quis mais...”, e o ajude 
a perceber os efeitos negativos de seu comportamento na vida do outro (Costa et al., 2013).

Orientação e supervisão parental, portanto, são cruciais na distinção de atitudes sexualmente invasivas ou violentas, de atitudes pertinentes ao estágio de desenvolvimento em que se encontra o adolescente, com parceiros(as) de sua faixa etária e interesses semelhantes (Costa et al., 2015; Oliver, 2007; Pincolini \& Hutz, 2014). A falta de preparo para o exercício da sexualidade e de monitoramento estão conectados tanto à vitimização de abuso sexual na infância, quanto à reprodução do mesmo (Hershkowitz, 2014).

Nas famílias de baixa renda, como as da pesquisa, os desafios à criação, proteção e à educação dos filhos são imensos. O excesso de demanda laboral, a falta de recursos financeiros e a pouca disponibilidade de infraestrutura no contexto extrafamiliar, como creches e escolas de turno integral, exige que as famílias recorram a estratégias de sobrevivência e a práticas parentais nem sempre adequadas (Cole \& Cole, 2004; Costa et al., 2015; Penso et al., 2012). O estilo autoritário, marcadamente rígido e com trocas afetivas insuficientes, costuma ser preponderante (Worley et al., 2012).

Hershkowitz (2014) acrescenta que crianças cujos pais trabalham longas horas do dia fora de casa ou um único genitor se responsabiliza pela prole - famílias monoparentais estão mais vulneráveis à ocorrência de situações ofensivas. Em síntese, o conjunto de variáveis relativas ao ambiente intra e extrafamiliar serve como pano de fundo para o entendimento deste tipo de interação.

\section{Pornografia, fantasias e masturbação}

Outro fator relacionado à situação de ofensa sexual relatada pelos adolescentes diz respeito ao acesso precoce à pornografia e, consequentemente, a fantasias sexuais e a masturbação. No discurso de Airton, percebe-se que o grupo de pares fez um forte apelo ao consumo de pornografia. Infere-se que o uso deste recurso pode ter servido de estímulo às 
suas fantasias e à prática ofensiva, pois, de acordo com a meta-análise de Seto e Lalumière (2010), a exposição prematura à sexo, à pornografia e à violência sexual predispõem ao comportamento sexual ofensivo. Latzman, Viljoen, Scalora e Ullman (2011) compartilham da mesma ideia. A conclusão de uma pesquisa desses autores, composta por 100 adolescentes - entre 13 e 17 anos de idade - que haviam cometido ofensa sexual contra irmãos e 66 adolescentes, contra indivíduos do contexto extrafamiliar, apontou que os agressores do ambiente intrafamiliar haviam sido mais expostos à pornografia, a comportamentos sexualizados no ambiente familiar e relatado episódios de vitimização sexual em maior proporção que os demais.

Quanto ao conteúdo das fantasias, segundo Marshall e Marshall (2000), alguns jovens relatam temas de poder, controle e violência ou imagens de crianças durante a atividade masturbatória. Denominadas de fantasias sexuais atípicas/desviantes, esse processo imaginativo é caracterizado pelo retraimento do indivíduo para o seu universo interior, cuja temática envolvida é ilegal ou inaceitável pela sociedade (Gee, Devilly \& Ward, 2004) e de ordem sádica e agressiva que causam danos intencionais a outrem (Prentky et al., 1989). De acordo com Hunter, Ram e Ryback (2008), essas fantasias serviriam como fuga de estados de tensão relacionados, principalmente, a situações de solidão e ansiedade. Os autores, baseados em um estudo de caso em que a conduta ofensora era protagonizada por um jovem de 19 anos contra crianças de ambos os sexos, entendem que as investidas do rapaz significavam uma tentativa de adquirir intimidade com suas vítimas e de escapar de estados de afeto negativos.

O estudo de caso de Hunter et al. (2008) é compatível ao discurso da mãe de Flávio a respeito da ansiedade exacerbada do filho e de sua preferência por interações com pessoas que ainda se encontram na infância: "Ele só quer brincar com criança pequena, ele não cresceu (...)". Por esta razão, é preciso avaliar se a interação do adolescente implica um dano 
potencial a outra pessoa, verificar se ambos estão na mesma faixa etária e se há presença de força ou coerção (ATSA, 2006).

Problemas de comportamento que envolvem a sexualidade podem surgir antes mesmo da pessoa atingir os 12 anos de idade (Murrie, 2012). No período que antecede a puberdade, algumas condutas de agressão sexual - por parte de crianças contra outras mais jovens - estão sujeitas a ocorrer (Hunter, 2012a), demonstrando que essa fase é um momento importante para o destino da sexualidade (Oliver, 2007). As tarefas do desenvolvimento, uma vez vividas de forma conturbada, dificultam ou até impedem que o indivíduo construa habilidades e competências para lidar com as situações do dia a dia e expressar seus impulsos (Marshall \& Barbaree, 1990).

Ademais, é esperado que, durante o processo de desenvolvimento, o indivíduo disponha de instrumental suficiente para fazer a discriminação dos impulsos agressivos dos sexuais e internalize as regras sociais; caso contrário as fantasias podem ser usadas para expressar raiva e desilusão em momentos de dor ou estresse (Marshall \& Barbaree, 2008). Em tais casos, a masturbação acaba sendo utilizada para enfrentar problemas e lidar com diversas situações. A pessoa recorre a esta estratégia não somente para obter prazer, mas também para enfrentar momentos de tensão e desconforto (Marshall \& Barbaree). A qualidade das fantasias, portanto, é um aspecto importante na compreensão do comportamento abusivo e merece especial atenção em programas interventivos (Oliver, 2007; Worling, 2012).

\section{Consequências do episódio ofensivo e responsabilização do adolescente}

Situações de ofensa sexual perpetradas por adolescentes têm consequências negativas não somente para as vítimas, como para os autores da violência e seus familiares 
(Jones, 2015). Do ponto de vista das vítimas, o medo e a vergonha em revelar o ocorrido contribuem para a manutenção do segredo, impedindo que o indivíduo procure alguém de sua confiança, relate o evento e receba a devida atenção (Marra, 2015). Em casos de ofensa no contexto intrafamiliar, os dilemas vividos pela criança que sofre a ação são ainda maiores, tendo em vista que inclui pessoas de um mesmo núcleo familiar, com relações consanguíneas (ou não) e que compartilham o espaço domiciliar (Costa, 2011).

Os pais, por sua vez, precisam arcar com uma dupla tarefa, uma vez que "têm sob sua responsabilidade uma criança vitimada e um adolescente vitimizador, além de um contexto no qual não conseguiram impedir a violência" (Costa, 2011, p. 194). Neste sentido, são considerados vítimas secundárias em virtude das diversas adversidades decorrentes dos episódios (Worley et al. 2012). Para driblar as alterações no sistema familiar e as críticas oriundas do ambiente extrafamiliar, muitos genitores recorrem a subterfúgios.

Pode haver uma tentativa de atenuar o problema e desqualificar a interação incestuosa estabelecida entre os irmãos, comprometendo a detecção e elucidação do episódio, conforme aparece no relato da mãe de Airton: “Eu entendi assim, que tinha ocorrido uma brincadeira, ocorrido mesmo uma masturbação, entendeu? Mas assim, do ato sexual, eu não pensava! (...) E foi um ato anal! ". A negação, como neste caso, é uma das possíveis reações de pais de adolescentes que cometem ofensa sexual (Heiman, 2002), pois, para eles, a experiência é tão avassaladora que adotam posturas defensivas para não tomar conhecimento sobre o que está acontecendo (Marra, 2015).

Admitir a ocorrência do episódio é uma árdua tarefa e envolve ambivalência, sentimento de impotência, autoacusação e culpa (Heiman, 2002; Jones, 2015), como no relato da genitora (Airton): "Sempre a mãe é culpada... só que nessa história, eu falo assim: Deus, eu não errei. Pelo contrário, fiz as coisas tudo certinha. Claro que a gente erra. Mas, a que mais tentou fazer tudo certinho, fui eu. E ainda aconteceu isso...". A verbalização 
demonstra o desapontamento vivido por esta mulher que, mesmo empenhada em cuidar de sua prole, não conseguiu perceber a situação, nem agir antes da ofensa ocorrer.

Apesar da resistência, as próprias vítimas sinalizam que algo não está bem, como nos casos de Léo e Airton. Elas solicitam aos genitores/responsáveis providências quanto ao comportamento do adolescente e indicam soluções para a questão. Mesmo que as vítimas não tenham revelado explicitamente o evento ofensivo, em ambos os casos, há um claro pedido de ajuda. Na família de Léo, a menina requisita que o adolescente seja punido: "Bate nele, bota ele de castigo"; enquanto na família de Airton, a criança sugere que o pai retorne à casa: “Ah mãe, por que você tá fora? Por que você não volta com o pai? ”. A força destes pedidos demonstra a necessidade do resgate da autoridade familiar (Minuchin, 1982) e da retomada do papel parental que foi abandonado (Costa, 2011) ou que nunca chegou a se consolidar. Para tanto, é fundamental criar um contexto protetivo, com figuras hierárquicas consistentes, que seja capaz de impedir a perpetuação da violência (Penso et al., 2012).

Assim, quando não existe mais a possibilidade de negar o ato, tanto por parte do adolescente quanto da família (Worling \& Langton, 2012), a atitude dos pais ou responsáveis para com o autor da ofensa pode ser de extrema aversão e hostilidade (Heiman, 2002) ou até de violência física. Neste estudo, percebe-se uma oscilação entre a adoção de práticas punitivas - bater no adolescente - e dialógicas, de acordo com a narrativa de Gaspar: "Eu fui lá falar pra minha avó, e ela falou que não queria saber. Aí de repente o pessoal queria me bater. Ela ficou um tempo sem vir, sem conversar comigo. Ai depois ela veio”. Essas declarações sugerem a crise instalada no sistema familiar como consequência da revelação (Worley et al., 2012) e a necessidade de reorganização dos membros deste núcleo para manejar a situação (Worling \& Langton, 2012) e seguir em frente.

Importante destacar que, no caso de Airton, os pais só tomaram contato com a situação de ofensa sexual por intermédio do Conselho Tutelar. Ou seja, a instituição tanto 
informou sobre a denúncia - oferecida pelo irmão mais velho de Airton contra o adolescente - como relatou os detalhes acerca do fato e dos procedimentos adotados em relação à vítima. Tal queixa, entretanto, é considerada uma exceção na medida em que familiares de adolescentes acusados deste tipo de ofensa procuram protegê-los do sistema judicial e mantê-los fora do alcance das autoridades (Ryan, 2012; Smith et al., 2005). De acordo com Costa (2011), “as famílias com adolescentes ofensores sexuais não buscam espontaneamente nenhum órgão do sistema de justiça para denunciar, nem mesmo o Conselho Tutelar” (p. 195) e, quando a denúncia acontece, geralmente é feita por algum profissional que compõe a rede social da família.

A falta de notificação pode ser atribuída a dois principais motivos. O primeiro deles diz respeito às crenças das famílias sobre o papel da justiça/polícia. Segundo o estudo de Costa (2011), para os denunciantes, essas instituições representam uma fonte adicional de dor e sofrimento. Ao invés de amparo, elas são vistas como pouco respeitosas e colaborativas, o que reforça a sensação de rechaço (Costa). O risco de a família ser vítima de estigmatização e isolamento são aspectos que desencorajam a efetivação da denúncia e geram dúvidas quanto à competência dos pais para lidar com o adolescente (Heiman, 2002). A sensação de fracasso é um dos maiores desafios a ser enfrentado pelos genitores (Marra, 2015) e requer a revisão dos deveres parentais e das práticas educativas adotadas (Jones, 2015; Worley et al. 2012). Dito de outro modo, quando é feita a denúncia, todo o grupo familiar fica suscetível a uma espécie de 'julgamento' e necessita se recompor para responder às demandas internas e externas a este grupo.

O segundo motivo para a ausência de notificação se refere aos desdobramentos e implicações, provenientes desta decisão, na trajetória do adolescente e dos demais componentes da família (Smith et al., 2005), isto é, a instauração do processo legal e aplicação de medidas coercitivas (Ryan, 2012) ou socioeducativas (Brasil,1990). Trata-se de 
um momento ansiogênico e perturbador em que a família responde tanto pela proteção da vítima, quanto do adolescente (Costa et al., 2011), encarregando-se de acatar as determinações impostas pela Lei (Jones, 2015). Em face a tais determinações, muitos pais não sabem como proceder e temem pelo futuro dos seus filhos.

Em alguns estados norte-americanos como Nova Jersey, Minnesota e Pennsylvania, por exemplo, os casos de ofensa sexual praticados por adolescentes podem ser julgados por tribunais de adultos e receber penas severas, com privação de liberdade. Neste país, existe ainda uma forma de registro compulsório destinada a adultos e a adolescentes que cometem ofensa sexual e que serve para o controle social (Ryan, 2012; Zimring, 2004). Uma vez inscrito nesta lista, o indivíduo e sua família têm suas identidades, dados pessoais e endereço expostos na web, tornando-se facilmente alvos de perseguições (Harris et al., 2015).

A investigação de Harris e Cudmore (2016), realizada junto a cidadãos que utilizam o referido registro, aponta que o principal motivo de acesso ao documento é a curiosidade, sendo que a sensação de insegurança do usuário é maior, à medida que nova consulta é feita ao banco de dados. Em síntese, a percepção de desproteção na comunidade continua a vigorar. Além disso, não há embasamento científico que comprove a prevenção de novos episódios ofensivos a partir do uso deste instrumento (Ryan, 2012), o que torna a medida polêmica.

Por outro lado, é consenso em diferentes nações que o adolescente deva ser responsabilizado (Barroso, 2012; Costa, 2011; Costa et al., 2015; Penso et al., 2012; Ryan, 2012; Seto \& Lalumiére, 2010; Worling \& Langton, 2012), pois, permitir que ele fique alheio às consequências de seus atos e não responda legalmente pelo que praticou é tão prejudicial quanto adotar medidas exageradas (Smith et al., 2005). Neste sentido, a responsabilização tem um papel relevante no percurso da pessoa envolvida com o sistema 
de justiça, desde que seja aplicada dentro de parâmetros de respeitabilidade e cidadania (Ward, Gannon \& Birgden, 2007).

Nos Estados Unidos, a propensão à punição ao invés da reabilitação dificulta a visão humanizada do sujeito, conforme preconizam Ward et al. (2007), e torna difícil sua recuperação. Sob a crença de um descontrole em relação aos índices gerais de criminalidade atribuídos aos jovens, ocorreu a partir dos anos 90 um incremento nas ações punitivas e de segurança (Spice et al., 2012), em detrimento a medidas interventivas (Ryan, 2012), apesar da multiplicação de modelos de atendimento a adolescentes e suas famílias nas últimas décadas (Worling \& Langton, 2012).

Particularmente ao contexto brasileiro, a responsabilização não pode se limitar à atribuição de uma medida socioeducativa designada pelo juiz, mas precisa ser abrangente e proporcionar ao adolescente um olhar sobre si mesmo. Essa é uma das conclusões do trabalho de Valente e Lopes de Oliveira (2015) ao efetuar a análise documental de textos legais sobre o processo de responsabilização e de uma pesquisa com operadores do sistema socioeducativo. Os participantes do estudo defenderam o foco pedagógico das medidas para além da questão jurídica. Contudo, segundo as autoras, ainda permanece um discurso antiquado e punitivo, cuja associação entre "impunidade e falta de leis mais rígidas e até retributivas, continuam sendo defendidas" (p. 867).

Diante desse paradoxo, o adolescente tem menos chance de refletir sobre sua conduta e seu futuro, e maior probabilidade de permanecer à margem da sociedade. Ademais, enquanto ele não for visto como um ser em desenvolvimento, que necessita de atenção individualizada e inserido em um contexto familiar, social e histórico (Penso et al., 2012), dificilmente o cumprimento da medida socioeducativa terá êxito. Sem sua participação ativa, as tensões entre culpabilização, punição e responsabilização tendem a se acirrar (Valente \& Lopes de Oliveira, 2015). 
A proteção ao adolescente em situação de ofensa sexual é o primeiro passo para reconhecer que a família, a sociedade e o Estado falharam em algum momento e são, por sua vez, corresponsáveis pela prática deste ato infracional. Ao mesmo tempo, essas instâncias constituem a base para a mudança do jovem e para a escolha de condutas mais assertivas destinadas a tirá-lo, em definitivo, da categoria infrator (Valente \& Lopes de Oliveira, 2015) ou ofensor (Penso et al., 2012). A responsabilização é, portanto, parte de um conjunto de medidas que começa no próprio adolescente e se estende a toda a sociedade (Conceição, 2010).

\section{Mudanças positivas em meio a adversidades}

De acordo com algumas verbalizações dos participantes deste estudo, houve menção não somente a consequências negativas, como também a mudanças positivas, decorrentes da situação de ofensa sexual. Um redimensionamento nas relações fraternais, parentais e conjugais indica que episódios dessa natureza podem ser também promotores de transformações positivas, como se deduz do seguinte intervalo: “Eles (os filhos) se uniram mais, se respeitaram mais... Até o meu relacionamento com o C. (marido) hoje, é um relacionamento de mais companheirismo” (Mãe de Airton).

Para tanto, o grupo familiar precisa passar por uma mudança abrangente que inclua o fortalecimento das figuras de autoridade, a redefinição de papéis, a implementação de fronteiras entre os membros do sistema fraternal, a construção de limites para o adolescente e, sobretudo, a aproximação entre pais e filhos para evitar novos episódios (Penso et al., 2012; Worley et al., 2012). Ainda sobre o caso Airton, a conversa de "homem pra homem" proposta pelo pai do adolescente após a descoberta do evento, parece suscitar uma nova fase na relação entre os dois. Até então, distantes um do outro, não haviam conseguido 
estabelecer uma relação de cumplicidade a ponto de tratar temas relevantes para o adolescente, como sexo, por exemplo.

Conforme discutido anteriormente, a falta de uma referência parental para Airton e a confusão entre os papéis assumidos por ele contribuíram para a situação ofensiva. Todavia, quando é possível retomar a comunicação, redefinir competências e negociar um espaço de troca no contexto familiar (Worley et al., 2012), todos podem ser beneficiados e sair fortalecidos dessa experiência.

\section{Conexão entre eventos: abuso e ofensa sexual}

A meta-análise empreendida por Seto e Lalumière (2010) assinala que a vitimização sexual aumenta em cinco vezes a probabilidade de conduta sexual ofensiva na adolescência, quando comparada a comportamentos transgressores de natureza não sexual. Um segundo trabalho de Seto, Kjellgren, Priebe, Mossige, Svedin e Langström (2010), realizado com 4.000 estudantes noruegueses e suecos do sexo masculino, sugere que a vivência de coerção sexual - considerada como qualquer forma de pressão ou força para manter contato sexual oral, anal, vaginal ou através de masturbação - é um fator de risco para prática de ofensa sexual, tanto para aqueles que escolhem vítimas crianças, quanto para os ofensores de pessoas de sua faixa etária ou adultos.

Tais referências colaboram para a compreensão do fenômeno sexual ofensivo e contextualizam a situação protagonizada por dois participantes deste estudo: Airton e Léo. Em ambos os casos, há relato de vitimização sexual e a reprodução do episódio no ambiente familiar, como explicitado na frase de Léo: "Eu tava assistindo televisão, eu me lembrei (do abuso sofrido), peguei... e fiz nela". Apesar de o adolescente referir que sente "raiva e ódio" quando questionado sobre sua vitimização, acaba por repetir o comportamento com duas irmãs menores. Para Finkelhor e Browne (1985) tal conduta deriva da experiência traumática 
pregressa. Segundo os autores, o abuso sexual gera a sensação de impotência e compromete o desenvolvimento sexual a ponto de causar confusão sobre a própria identidade, desencadear disfunções sexuais ou comportamentos sexuais inadequados e ofensivos. Mesmo tratando-se de uma experiência potencialmente aversiva, a identificação entre vítima e agressor não é incomum e envolve um processo de elaboração delicado (Penso \& Neves, 2008).

No caso do adolescente Airton, há também uma cena semelhante que envolve a irmã por ele abusada: "Ai depois que aconteceu, ela (vítima) foi "brincar" com um outro menino... aí minha mãe falou com ela”. Ou seja, a menina replica sua vivência com uma criança no ambiente da casa. $\mathrm{O}$ ato sugere que, por mais doloroso que tenha sido o episódio abusivo, ele pode ter servido de exemplo para outras interações, até porque o processo de simbolização efetuado pela criança parece estar em curso e não concluído. Segundo Araújo (2002) "são muitos os processos de subjetivação produzidos no percurso de elaboração dessas experiências" (p. 8), podendo influir na repetição de um padrão familiar e na transmissão transgeracional desta conduta (Marra, 2015; Penso \& Neves, 2008).

É preciso cultivar fatores protetivos que possam evitar a repetição do comportamento ofensor em indivíduos vítimas de abuso sexual na infância, conforme aponta a pesquisa de Lambie e Johnston (2015). A investigação sustenta que receber suporte emocional regular de algum familiar, amigo ou parente adulto, após os eventos, constitui um dos principais componentes para a resiliência e serve de modelo positivo. Nestes casos, a chance de identificação com o perpetrador da violência diminui, cedendo lugar a padrões de relacionamentos mais empáticos e apoiadores.

Por fim, a fala da mãe de Léo corrobora a relação entre os dois eventos, abuso e ofensa sexual: "A minha preocupação com o que aconteceu lá atrás é que, pelo que eu percebi, e eu posso tá errada, (...) a atitude que ele tomou foi uma reflexão, um... um... assim, 
foi um reflexo do que aconteceu com ele”. Para ela, está nítido que o abuso sofrido pelo filho no contexto escolar ainda não foi completamente superado ou esquecido, mas foi atualizado (Penso \& Neves, 2008). E é sobre este tema que as famílias necessitam, o mais rapidamente possível, se dispor a tratar.

Em contrapartida, o intervalo de tempo entre a ocorrência do episódio ofensivo e a chegada para atendimento institucional pode não ser imediata. Neste estudo, a família de Léo ingressou na instituição (COMPP) nove meses após a denúncia, enquanto a família de Airton, dois anos depois. Outro detalhe que chama a atenção é o motivo do encaminhamento para a instituição, isto é, duas famílias foram conduzidas em função de atendimento à vítima. Somente depois de iniciada a intervenção, a história da ofensa foi revelada.

A hipótese mais provável para explicar a busca de ajuda para o indivíduo vitimado e não para o adolescente que cometeu a ofensa é o fato de a vitimização sexual ter mais visibilidade (Bianchini \& De Antoni, 2012) e contar com uma rede de atendimento (Paixão \& Deslandes, 2010) um pouco mais consistente do que para o autor da violência (Espindola \& Batista, 2013). Outra hipótese é o preconceito em torno do assunto. Segundo Marra (2015), “a insegurança e as desconfianças geradas pelo relato do abuso sexual, no primeiro momento, impedem uma aproximação necessária entre os familiares para a tomada de decisão de revelar e publicizar a situação" (p. 109).

Ora, se para eles, aceitar a ocorrência de abuso sexual intrafamiliar é uma missão complicada, mais difícil será assimilar que o agressor é o irmão/primo/vizinho adolescente da vítima. De qualquer maneira, tomar providências para evitar a repetição do ato é um dever da família, tendo em vista que ser vítima de abuso sexual antes dos 14 anos de idade predispõe à prática de ofensa sexual em um período inferior a um ano, conforme sugere a investigação de Hershkowitz (2014). Por esta razão, é importante identificar os fatores de 
risco para a reincidência e construir medidas interventivas capazes de auxiliar o adolescente a trilhar um novo caminho.

\section{Discussão dos Resultados 2 e 3}

\section{Fatores de risco para a reincidência e perspectiva de futuro}

Diferentes aspectos de ordem pessoal, familiar, psicossocial e interventiva podem constituir fatores de risco para a reincidência de agressão sexual em adolescentes, de acordo com o checklist ERASOR (Worling \& Curwen, 2001). Para evitar novos episódios, é necessário conhecer os adolescentes da maneira mais ampla possível a fim de identificar seus comportamentos e poder elaborar estratégias adequadas e individualizas. Os autores do checklist (Worling \& Curwen) recomendam que os profissionais façam um julgamento clínico para avaliar o risco de reincidência - classificado como baixo, moderado ou alto com base no conjunto de fatores, mais do que em algum deles de forma isolada.

Com o objetivo de sintetizar os resultados do ERASOR e agregar informações sobre a perspectiva de futuro, optou-se por reunir dois participantes, Léo e Airton, ambos com vivência de abuso sexual, apesar de apresentarem diferentes fatores de risco para a reincidência, e discutir separadamente os outros dois, Flávio e Gaspar, conforme segue:

\section{Léo e Airton}

Os fatores de risco a serem destacados são interesses sexuais desviantes (crianças, violência ou ambos), preocupação com pensamentos sexuais e crime sexual contra duas ou mais vítimas, presentes na avaliação de Léo. A este adolescente é atribuída a autoria de ofensa sexual contra duas pessoas do seu contexto intrafamiliar: a irmã de oito e a irmã de três anos de idade. É provável que o conteúdo inadequado de suas fantasias, envolvendo 
crianças ou coerção, por exemplo (Marshall \& Marshall, 2000), estejam colaborando para o retraimento de Léo ao seu universo interior e dificultando interações com pessoas de sua faixa etária (Gee et al., 2004).

Com base no conjunto dos fatores de risco, se pode supor que além das dificuldades do adolescente para conter seus impulsos e pensamentos, há uma fragilidade no subsistema parental quanto ao estabelecimento de limites e fronteiras entre os membros da família (Minuchin, 1985; Penso et al., 2012). Ademais, o comportamento sexualizado e reiterado do adolescente frente às irmãs, sugere que a violação sexual vivida por ele no contexto escolar está ainda pendente (Hershkowitz, 2014) e representa um dano potencial (Araújo, 2002; Penso \& Neves, 2008).

Talvez, por esta razão, quando perguntado sobre sua perspectiva de futuro, Léo mencione a existência de "uma porta com luz e com escuridão". Tais opostos podem revelar os conflitos, a ambivalência e as dúvidas experimentadas pelo adolescente diante de tantos desafios a serem enfrentados. Outro detalhe que chama atenção é o cenário desenhado por ele. Léo se vê matriculado na escolinha de futebol, local carregado de significado, pois foi neste contexto que sofreu o abuso sexual. Segundo relatos de Léo, as questões relacionadas ao episódio não foram completamente clarificadas ou resolvidas e sua família não conseguiu perceber as mudanças nas atitudes de Léo na ocasião do abuso, o que o deixou ainda mais vulnerável (Lambie \& Johnston, 2015).

Neste sentido, foi incluído no item 26 do checklist ERASOR o fator de risco prévia vitimização sexual. O mesmo fator também está presente na avaliação de Airton, sendo que há similaridades entre o comportamento dos dois jovens e entre a reação de seus responsáveis no que se refere à revelação da vitimização sexual sofrida por ambos, isto é, a dificuldade em perceber que algo havia acontecido ao adolescente. Portanto, neste estudo, 
prévia vitimização sexual constitui um fator de risco para a reincidência de agressão sexual, ainda que os trabalhos não sejam unânimes a esse respeito (Worling \& Curwen, 2001).

Pelos relatos, se deduz que não foi realizado atendimento para trabalhar as experiências abusivas vivenciadas por Léo e por Airton, cujo conteúdo permanece não elaborado, constituindo uma fonte de tensão e estresse. Penso e Neves (2008) asseveram, por exemplo, que pessoas que não conseguem ser acolhidas e protegidas por seus cuidadores em situação de violência sexual podem se manter em estado de pane, caracterizado por "uma grande indiferenciação entre o discurso e o agir, o objetivo e o subjetivo, o passado e o presente, o familiar e o social” (p. 138), como se observa nos dois casos.

Segundo Sell e Ostermann (2015), a fala-em-interação é um instrumento “de empoderamento das vítimas de abuso sexual, na medida em que é através da linguagem em uso que as crianças e os/as adolescentes organizam, elaboram e ressignificam sua experiência" (p. 325). Assim, o processo interventivo poderá se constituir em uma ferramenta importante para a escuta destes jovens e contribuir para elucidar as conexões entre a situação de vitimização e a prática de ofensa sexual.

Ajudar o indivíduo a dar sentido à vivência traumática é um caminho para evitar sua revitimização e impedir a atuação de comportamentos indesejáveis (Finkelhor \& Browne, 1985). As intervenções, nestes casos, devem focalizar aspectos pessoais, interpessoais e familiares (Borduin et al., 2009) com o intuito de evitar a cristalização de condutas, impedir a repetição dos atos e dirimir os sintomas (Penso \& Neves, 2008).

Outro fator de risco que se destaca na avaliação de Airton é a utilização de pornografia, categorizada como interesses sexuais obsessivos. Segundo Hunter (2012a), muitos indivíduos têm acesso à pornografia antes mesmo da puberdade, sendo que este comportamento está associado a prática sexual ofensiva, embora ainda não exista uma compreensão completa quanto ao mecanismo que induz a tal conduta. O autor destaca que é 
preciso investigar também variáveis como aspectos culturais, familiares e grupo de pares relativos ao consumo de pornografia, que podem atenuar ou precipitar as atitudes ofensivas.

Por outro lado, de acordo com a avaliação do ERASOR, há diferenças entre o funcionamento familiar/ambiental de Léo e Airton. Este último dispõe de um contexto familiar mais consistente, no qual não há presença de rejeição parental, nem relação problemática com os genitores. Infere-se que Airton desfrute de uma condição favorável à integração das vivências, em virtude do apoio oferecido por sua família (Lambie \& Johnston, 2015). O desenho e o discurso sobre sua perspectiva de futuro traduzem seus anseios para adquirir autonomia, reconquistar a confiança dos pais e suplantar as dificuldades decorrentes da situação ofensiva. Em paralelo, o adolescente demonstra o desejo de reatar com a exnamorada, pessoa que pertence a sua faixa etária e com quem já estabeleceu uma relação amorosa. Portanto, a escolha de Airton por uma parceira de sua idade é adequada e compatível ao seu momento de desenvolvimento (Hunter, 2012b). Léo, ao contrário, necessita de intervenção específica para dirimir a elevada probabilidade de reincidência.

\section{Flávio}

No que tange ao adolescente Flávio, outros fatores de risco foram identificados pela equipe. Os que mais chamam a atenção se referem ao Funcionamento Psicossocial, ou seja, relações interpessoais instáveis e isolamento social, recente escalonamento de raiva e sentimentos negativos, e autorregulação deficitária dos afetos e comportamentos. Esses fatores são compatíveis à descrição do adolescente, de sua história pregressa e da vivência de episódios de violência, lembrando que Flávio foi vítima de bullying e apresenta ideação suicida.

Quanto ao Funcionamento Familiar/Ambiental, é possível perceber que todos os fatores foram assinalados e que precisam ser trabalhados de maneira intensa. Entretanto, sem 
amparo da família, em especial de seus responsáveis, será difícil a reorganização do sistema familiar, bem como a proteção do adolescente. Para superar as adversidades decorrentes dos episódios de bullying e da acusação da prática de ofensa sexual, Flávio necessitará de uma rede apoio efetiva e da participação da família no atendimento (Borduin et al, 2009; Worley et al., 2012). A evasão e a falta de comprometimento por parte de seus genitores podem levar a dificuldades no tratamento e à descrença na construção de uma trajetória de desenvolvimento mais saudável para o adolescente (Nahum \& Brewer, 2004).

Para Hunter (2012b), adolescentes com essas características têm uma tendência a se aproximarem de crianças pequenas como forma de compensar sua baixa autoestima e suas poucas habilidades sociais. Em tais casos, programas de atendimento ambulatorial realizados na comunidade devem fomentar a inserção desses adolescentes em contextos acolhedores, de forma a melhorar sua performance social e desenvolver um repertório comportamental adequado para interagir com seus pares.

Quanto à figura da porta, o desenho associado às frases sugere uma tentativa de Flávio lidar com as adversidades vividas internamente (medos, desproteção, baixa autoestima) e externamente (acusação da prática de ofensa sexual, revelação recente sobre sua filiação, violência intrafamiliar e extrafamiliar). A solução encontrada pelo adolescente para a resolução dos conflitos agrega elementos de idealização, como força, poder e determinação (observados em seu autorretrato), opostos à sua atual situação. Em síntese, o desenho de Flávio indica uma tendência à fuga ou à busca por soluções mágicas para ultrapassar os obstáculos.

\section{Gaspar}

Por último, há o fator de risco crime sexual contra vítima do sexo masculino, presente apenas no ERASOR de Gaspar. Segundo Costa et al. (2015), a ofensa cometida por meninos 
contra meninos é um fenômeno que se enquadra na categoria das violências sexuais, embora não seja notificado, nem devidamente tratado. A ofensa sexual desta natureza é, muitas vezes, invisível devido à falta de distinção entre uma situação lúdica e uma situação invasiva ou perniciosa (Costa et al., 2015; Oliver, 2007).

Estima-se que a escolha de Gaspar por uma vítima do sexo masculino não tenha sido aleatória, tendo em vista que no contexto intrafamiliar onde ocorreu a ofensa, haviam outras crianças e jovens do sexo oposto em situação de vulnerabilidade, conforme descrito na seção dos resultados. Tais elementos são sugestivos de reincidência, de acordo com Langström e Grann (2000).

Do ponto de vista do funcionamento psicossocial, a equipe entendeu que há orientação interpessoal antissocial, envolvimento com pares desviantes e com influência negativa, autorregulação deficitária dos afetos e provável escalonamento de raiva e sentimentos negativos. Também foram pontuados todos os fatores de risco relativos ao funcionamento familiar/ambiental. Em conjunto, esses aspectos levantados no checklist de Gaspar são compatíveis à sua história pregressa e sugerem um modelo de intervenção um pouco diferente dos demais participantes do estudo.

É necessário, por exemplo, oferecer a Gaspar um atendimento capaz de trabalhar e entender sua adesão a outros tipos de ofensas, que não sexuais, como a prática de furtos. Neste contexto, o grupo de pares costuma colaborar para as condutas antissociais, na qual o adolescente encontra um campo fértil para treinar e perpetuar comportamentos desviantes (Braga \& Gonçalves, 2011). Por isso, é importante dispor de uma abordagem que inclua diferentes pessoas de seu ciclo de relações e figuras de autoridade mais positivas, além da avó materna, que, no momento, é a única a se responsabilizar por ele. Os adolescentes que apresentam tanto comportamentos sexuais ofensivos, como comportamentos ofensivos não- 
sexuais são propensos a prognósticos reservados e podem ser mais refratários ao tratamento (Butler \& Seto, 2002; Ryan, 2012).

Quanto à perspectiva de futuro, o relato de Gaspar unido à expressão gráfica, sugere uma indefinição de sua trajetória. Para aderir à tarefa solicitada pela equipe, por exemplo, o adolescente utilizou uma folha extra para desenhar, sem a figura da porta. Além disso, explorou o espaço de forma muito tímida e limitada, indicando que tem dificuldades para se colocar em cena e se posicionar. Suas verbalizações denotam confusão e incertezas, compatíveis a sua realidade atual. Conforme discutido anteriormente, os recursos familiares disponíveis ao adolescente são bastante restritos e ele não conta com outras pessoas ou instituições para apoio, enquanto que seus recursos internos parecem desvitalizados, como se observa em suas declarações: "Porque eu tenho sopro no coração. De vez em quando eu jogo bola no colégio, aí canso rápido (...)”. Gaspar faz tentativas de se situar em meio a diversas adversidades, como rejeição parental, abandono afetivo, dificuldades escolares, envolvimento em outros tipos de transgressões e ausência de modelos positivos (Hunter, 2012b; Penso et al., 2012; Worley et al., 2012). A falta de uma organização familiar com condições de prover limites e apoio a Gaspar (Lambie \& Johnston, 2015) podem dificultar seu processo de responsabilização e reparação pelo ato cometido (Costa et al., 2011). 


\section{CONSIDERAÇÕES FINAIS}

A ofensa sexual protagonizada por adolescentes é um problema de saúde pública que implica inúmeras consequências para as vítimas (Bianchini \& De Antoni, 2012), assim como para os perpetradores e seus familiares (Worley et al., 2012), tratando-se de um fenômeno complexo e heterogêneo (Butler \& Seto, 2002; Ryan, 2012; Worling \& Langton, 2012) "tanto em termos de características pessoais, do tipo de vítima ou do tipo de comportamentos sexualmente agressivos" (Barroso, 2012, p. 65). As ofensas cometidas intrafamiliarmente, por sua vez, costumam ser praticadas contra irmãos, primos ou outras crianças que frequentam o mesmo ambiente e podem ser interpretadas como uma brincadeira por parte dos autores dos episódios (Costa et al., 2015), indicando a necessidade de cuidado e orientação a estes jovens, especialmente sobre o despertar da sexualidade e suas manifestações.

Observa-se também que muitos jovens vivem em contextos não protetivos, sob variadas formas de violência e desrespeito à condição de pessoas em desenvolvimento (Penso et al., 2012), além de estarem mais expostos à vitimização sexual (Latzman et al., 2011), à pornografia e a comportamentos sexualizados em tenra idade (Seto \& Lalumière, 2010). Para responder a situação de ofensa sexual, é importante contar com espaços de atendimento construídos para o público infanto-juvenil e seus familiares, bem como com um corpo de profissionais capacitados para receber pessoas nesta condição.

No que diz respeito à abordagem teórica, no contexto nacional (Costa et al., 2011; Costa et al., 2015) assim como no internacional (Nahum \& Brewer, 2004; Worley et al., 2012;), a metodologia do Grupo Multifamiliar (GM) e a perspectiva sistêmica são recursos usados para compor as intervenções, sobretudo com famílias economicamente desfavorecidas. Segundo Nahum e Brewer, trata-se de uma forma sofisticada de troca, 
transferência de conhecimento e orientação entre famílias que vivenciam situações similares e que necessitam encontrar soluções a seus problemas em um ambiente seguro e emancipatório. A afirmação de Costa et al. (2011) reforça a ideia da importância deste recurso, ou seja, "a inclusão da perspectiva familiar no tratamento é relevante para a sua eficácia por ser um agente favorável para evitar a reincidência do ato violento, de melhora do compromisso do jovem com o tratamento e de prevenção da violência transgeracional" (p. 451).

Por outro lado, embora seja consenso que a violência sexual (Paixão \& Deslandes, 2010) e interpessoal possam ser evitadas, parece haver uma falta de comprometimento coletivo para impedir que crianças e adolescentes se transformem em adultos abusivos, mesmo com os conhecimentos já disponibilizados pela ciência em termos de prevenção (Ryan, 2005). Para buscar alternativas e oferecer uma resposta ao problema, é indicado adotar referenciais e parâmetros pertinentes à área da saúde pública. O modelo integrativo de Weisz, Sandler, Durlak e Anton (2005) é um deles, cuja proposta está baseada na conexão entre promoção de saúde, prevenção e tratamento.

Neste modelo, as intervenções promotoras de saúde têm por objetivo proporcionar o desenvolvimento de habilidades e recursos pessoais para o enfrentamento das adversidades. A prevenção, por seu turno, é mais ampla e abrange três dimensões: a universal, a seletiva e a indicada. A primeira delas, prevenção universal, é designada para abarcar toda a população; a seletiva, por outro lado, se direciona somente à parcela que apresenta risco elevado, em virtude de determinadas características; e, a indicada, é focada em pessoas que têm sintomas, mas que ainda não tiveram situações que justificaram tratamento (Muñoz, Cuijpers, Smit, Barrera \& Leykin, 2010).

Esse modelo pode servir para embasar a criação de intervenções destinadas às situações de ofensa sexual cometidas no contexto intrafamiliar. Para o planejamento destas 
intervenções, há dois eixos a serem considerados. O primeiro exige ações para evitar o surgimento de novos casos e, o segundo, para impedir que adolescentes que já praticaram ofensas sexuais, voltem a repetir o mesmo comportamento.

Com base nesta ideia, o checklist ERASOR foi empregado no estudo para ampliar o conhecimento acerca dos fatores de risco para a reincidência e ajudar no planejamento interventivo a esses adolescentes. Entende-se que o instrumento ERASOR inaugura um olhar diferenciado para o processo de tratamento no contexto brasileiro. Até o momento, a modalidade de Grupo Multifamiliar dirigido a essa população tinha como objetivo interromper a transmissão transgeracional da ofensa/abuso sexual, compreender o fenômeno e auxiliar a família a lidar com os episódios (Costa et al, 2009) sem, contudo, dispor de um recurso científico.

O checklist ERASOR (Worling \& Curwen, 2001) veio preencher esta lacuna, pois se baseia em fatores de risco sustentados empiricamente. A partir de agora, a equipe dispõe deste mecanismo, não somente para detectar o risco de reincidência, como também para construir intervenções personalizadas e adaptadas à necessidade de cada caso (Worling \& Langton, 2012). A inserção do ERASOR, neste estudo, buscou explorar e conhecer tais fatores, muito mais do que avaliar se o risco de reincidência dos participantes é baixo, moderado ou alto, conforme preconizado no instrumento. A utilização do checklist foi pensada para agregar informações sobre os adolescentes e seus familiares de forma objetiva, servir como um guia para elencar os principais fatores de risco, construir intervenções específicas e motivar a equipe a novos desafios.

Em razão do caráter inédito, entende-se que há muito a avançar em termos práticos para que o ERASOR passe, de fato, a fazer parte da rotina dos profissionais da instituição. Seria importante, por exemplo, incluir nos demais instrumentos dirigidos à família questões pertinentes aos fatores de risco, a fim de facilitar o preenchimento do mesmo. Também se 
recomenda que os profissionais tenham um tempo para se dedicar ao checklist e discutir a melhor forma de completá-lo, isto é, individualmente ou em grupo, como realizado nesta tese. É necessário que a equipe consiga integrar as diferentes visões dos adolescentes e de suas famílias a fim de propor uma intervenção capaz de reduzir as chances de recidiva.

Quanto à escuta individual do adolescente, proposta pela doutoranda, observa-se que o referido formato se mostrou valioso. Através da criação deste espaço, foi possível detectar que dos quatro participantes do estudo - Airton, Flávio, Gaspar e Léo - pelo menos um deles, o adolescente Airton, revelou ter sido vítima de abuso sexual na infância durante essa conversa, assunto considerado tabu em sua família. Ainda neste contexto, foi proposta a utilização de um terceiro instrumento, que ajudou a conhecer a perspectiva de futuro dos quatro adolescentes.

Nota-se que eles conseguiram se colocar de maneira distinta da que se colocavam até o momento. A criação de um espaço individual de escuta os elevou à categoria de protagonistas de suas histórias, onde puderam relatar suas próprias experiências, antes demandadas somente à família, e antever as possibilidades de um futuro próximo. Portanto, a situação de ofensa sexual intrafamiliar, embasada na perspectiva sistêmica e apoiada em outros instrumentos, permite a compreensão ampliada do fenômeno, o entendimento das circunstâncias envolvidas nos episódios, os atores que fazem parte da trama e as variáveis que contribuem para o surgimento do comportamento.

Infere-se que o presente estudo tenha contribuído para integrar informações a respeito da trajetória pregressa dos adolescentes, conectando vivências de violência física, emocional e principalmente sexual, às ofensas por eles praticadas. Este último elemento - vitimização sexual do perpetrador - não fazia parte da abordagem interventiva nos grupos Multifamiliares (GM) e tampouco era questionada. Em outras palavras, as sessões 
abordavam apenas a "má" conduta do jovem, sem conectá-la a eventos estressores vividos anteriormente.

Com base no ERASOR e no conteúdo da entrevista - ainda que reduzida em virtude das limitações institucionais - pôde-se observar que a reincidência precisa ser evitada, sobretudo para os adolescentes que não tiveram apoio no contexto familiar na época em que sofreram abuso. Além disso, conforme aponta Rasmussen (1999), o atendimento ao jovem autor de ofensa sexual não deve ser apenas direcionado a prevenir a reincidência, mas deve contemplar a interrupção de qualquer comportamento delinquente, promover sua responsabilização e impedir condutas que violem o direito alheio.

Para Olds et al. (1998), testar a validade de intervenções preventivas representa um longo processo que envolve recursos econômicos e humanos. Do ponto de vista metodológico, geralmente os estudos exigem uma amostra grande de participantes, com grupo controle e continuadas sessões de follow-up. Contudo, essas não são razões que justifiquem a falta de iniciativas. Pesquisas com um número reduzido de participantes, de caráter qualitativo, como o presente estudo, também podem ajudar a avançar sobre o fenômeno da ofensa sexual protagonizada por adolescentes.

Com base neste argumento, instrumentos dirigidos a avaliar os riscos de reofensa vêm sendo desenvolvidos para ampliar o conhecimento sobre quais fatores de risco e de proteção colaboram para evitar ou aumentar as chances de reincidência (Worling \& Langton, 2012) e, assim, aprimorar os que já existem. Há, portanto, a necessidade de estudos empíricos que deem suporte às estratégias interventivas e, posteriormente, aos programas preventivos. De acordo com Worling e Langström (2003), é preciso uma sistematização dos dados, tornando mais eficiente a comunicação entre instituições, como o Sistema de Justiça, e os profissionais da saúde. 
Cabe destacar, ainda, que a transferência de novos conhecimentos, frutos da academia e de centros pesquisa, esbarra em diversos obstáculos e não constitui um processo simples, automático e imediato. Evidências de eficácia e efetividade, aproximação entre a comunidade científica e os gestores das políticas públicas, e recursos humanos capacitados são alguns itens que necessitam ser averiguados e aperfeiçoados antes da implantação de um programa, por exemplo (Murta, 2011). Só assim, a sociedade poderá, de fato, usufruir dos benefícios e avanços que a ciência produz. 


\section{REFERÊNCIAS}

Abreu, M. \& Martinez, A. F. (1996). Olhares sobre a criança no Brasil: Perspectivas históricas. In I. Rizzini (Eds.), Olhares sobre a criança no Brasil, séculos XIX e XX (pp. 19-37). Rio de Janeiro: Editora Universidade Santa Úrsula.

Alves, C., Pedroza, R., Pinho, A., Presotti, L. \& Silva, F. (2009). Adolescência e maioridade penal: reflexões a partir da Psicologia e do Direito. Psicologia Política, 9(17), 67-83.

American Psychiatric Association (APA) (1999). American psychiatric association task force on sexually dangerous offenders. Washington, DC: Author.

Araújo, M. F. (2002). Violência e abuso sexual na família. Psicologia em Estudo, 7(2), 3-11.

Association for the Treatment of Sexual Abusers - ATSA (2006). Report of the Task Force on Children with Sexual Behavior Problems. Author.

Barbaree, H. E., \& Marshall, W. L. (2006). An introduction to the juvenile sex offender: Terms, concepts, and definitions. In H. E. Barbaree, \& W. L. Marshall (Eds.), The juvenile sex offender (2 ed) (pp. 1-18). New York: Guilford Press.

Barber-Madden, R., \& Saber, B. A. (2010). A situação dos jovens no mundo. In R. BarberMadden \& T. F. Santos (Eds.), A juventude brasileira no contexto atual e em cenário futuro (pp. 17-39). Brasília: UNFPA.

Bardin, L. (1977). Análise de conteúdo. Lisboa: Edições 70.

Barroso, R. N. S. G. (2012). Características e especificidades de jovens agressores sexuais. Tese de Doutorado. Universidade de Aveiro: Portugal.

Barroso R. G., Leite, A. L., Manita, C., \& Nobre, P. (2011). Between public agenda and the emergence of intervention programmes: Sexual offenders within the Portuguese context. Sexual Offender Treatment, 6(2), 1-10.

Barroso R. G., \& Manita, C. (2012). ERASOR - Estimativa de risco de reincidência de agressão sexual em adolescentes. Versão portuguesa 2.0. 
Berg, B. L. (2007). Qualitative research methods for the social sciences (6 $6^{\mathrm{a}}$ ed.). Boston: Allyn and Bacon.

Bianchini, F., \& De Antoni, C. (2012). Adolescentes que abusam sexualmente de crianças ou de outros adolescentes. In L. F. Habigzang \& S. H. Koller (Eds.), Violência contra crianças e adolescentes: teoria, pesquisa e prática (pp. 123-133). Porto Alegre: Artmed.

Borduin, C. M., Schaeffer, C. M., \& Heiblum, N. (2009). A randomized clinical trial of multisystemic therapy with juvenile sexual offenders: Effects on youth social ecology and criminal activity. Journal of Consulting and Clinical Psychology, 77, 26-37.

Borges, A. L. V., \& Nakamura, E. (2009) Normas sociais de iniciação sexual entre adolescentes e relações de gênero. Revista Latino-Americana em Enfermagem, 17(1), 94-100.

Borges, D., \& Cano, I. (2014). Programa de Redução da Violência Letal. Homicídios na adolescência no Brasil em 2012. Rio de Janeiro: Observatório de Favelas.

Braga T., \& Gonçalves, R. A. (2011). Avaliação psicológica de jovens ofensores. In M. Matos, R. A. Gonçalves \& C. Machado (Eds.), Manual de psicologia forense: Contextos, práticas e desafios (pp. 271-290). Braga: Psiquilibrios.

Brasil (1990). Lei nº 8069, de 13 de julho de 1990: Estatuto da Criança e do Adolescente. Retirado em 12 de junho de 2013, em http:// www.planalto.gov.br.

Brasil (2001). Plano nacional de enfrentamento da violência sexual infanto-juvenil. Ministério da Justiça, Brasília/DF.

Brasil (2010). Estatuto da Criança e do Adolescente. Atualizado com a Lei no 12.010 , de 3 de agosto de 2009. Tribunal de Justiça do Distrito Federal: Série Legislação Fundamental.

Brasil (2013). Plano nacional de enfrentamento da violência sexual contra crianças e adolescentes. Secretaria de Direitos Humanos, Brasília/DF. 
Budd, K., \& Desmond, S. A. (2014). Sex offenders and sex crime recidivism: Investigating the role of sentence length and time served. International Journal of Offender Therapy and Comparative Criminology, 58(12), 1481-1499.

Butler, S. M., \& Seto, M. C. (2002). Distinguishing two types of adolescents sex offenders. American Academy of Child and Adolescent Psychiatry, 41(1), 83-90.

Caldwell, M. F. (2010). Study characteristics and recidivism base rates in juvenile sex offender recidivism. International Journal of Offender Therapy and Comparative Criminology, 54, 197-212.

Carinhanha, J. I., \& Penna, L. H. G. (2012). Violência vivenciada pelas adolescentes acolhidas em instituição de abrigamento. Texto \& Contexto Enfermagem, 21(1), 68-76.

Carpentier, J., Leclerc, B., \& Proulx, J. (2011). Juvenile sexual offenders: Correlates of onset, variety, and desistence of criminal behavior. Criminal Justice and Behavior, 38, 854-873.

Carter, B., \& McGoldrick, M. (1995). As mudanças no ciclo de vida familiar: uma estrutura para a terapia familiar ( $2^{\mathrm{a}}$ ed). Porto Alegre: Artes Médicas.

Cole, M., \& Cole, S. (2004). O desenvolvimento da criança e do adolescente. Porto Alegre: Artmed.

Companhia de Planejamento do Distrito Federal - CODEPLAN (2015). Jovens e medidas socioeducativas: Determinantes da reincidência e de suas percepções. Recuperado em janeiro de $2016 \quad$ de www.codeplan.df.gov.br/images/CODEPLAN/PDF/pesquisa_socioeconomica/Estudos $\underline{12015 /}$

Conceição, M. I. G. (2010). A clínica do adolescente em meio fechado: olhares sobre o contexto. In M. M. Marra \& L. F. Costa (Eds.), Temas da clínica do adolescente e da família (pp. 87-103). São Paulo: Ágora. 
Conceição, M. I. G., \& Penso. M. A. (2015). O Estatuto da Criança e do Adolescente e as atribuições do Conselho Tutelar diante das famílias. In L. F. Costa, M. A. Penso \& M. I. G. Conceição (Eds.), Abordagem à família no contexto do Conselho Tutelar (pp. 41-48). São Paulo: Ágora.

Conselho Nacional de Justiça - CNJ (2012). A execução das medidas socioeducativas de internação: Programa justiça ao jovem. Brasília: CNJ.

Costa, B., \& Costa, L. (2013). Perpetrador e vítima: o adolescente que cometeu ofensa sexual. Revista Latinoamericana de Ciencias Sociales, Niñez y Juventud, 11, 541-553.

Costa, L. F. (2010). A perspectiva sistêmica para a clínica da família. Psicologia: Teoria e Pesquisa, 26, 95-104.

Costa, L. F. (2011). Participação de famílias no Grupo Multifamiliar de adolescentes ofensores sexuais: Vergonha e confiança. Psicologia Clínica, (23)1, 185-201.

Costa, L. F., Almeida, T. M. C.; Ribeiro, M. A. \& Penso, M. A. (2009). Grupo Multifamiliar: Espaço para a escuta das famílias em situação de abuso sexual. Psicologia em Estudo, 14(1), 21-30.

Costa, L. F., Junqueira, E. L., Meneses, F. F. F., \& Stroher, L. M. C. (2013). As relações familiares do adolescente ofensor sexual. Psico-USF 18 (1), 33-44.

Costa, L. F., Junqueira, E. L., Meneses, F. F. F., Stroher, L. M. C., \& Moura, M. G (2012). Construindo conhecimento sobre o adolescente que cometeu ofensa sexual. Contextos Clínicos, 5(2), 112-120.

Costa, L. F., Marreco, D. F., Barros, J. F., \& Chaves, M. N. S. G. (2015). Meninos préadolescentes que abusam sexualmente de meninos. Acta Psiquiátrica y Psicológica de América Latina, 61(1), 80-88.

Costa, L. F., \& Penso, M. A. (2014). A compreensão da família como sistema. In L. F. Costa, M. A. Penso \& M. I. G. Conceição (Eds.), Abordagem à família no contexto do conselho 
tutelar (pp. 49 - 59). São Paulo: Àgora.

Costa, L. F., Penso. M. A. \& Conceição, M. I. G. (2015). Os referenciais teóricos do Grupo Multifamiliar. In L. F. Costa, M. A. Penso \& M. I. G. Conceição (Eds.), Manual de Grupos Multifamiliares (pp. 18-28). Brasília: Central de Produções Gráficas e Editora.

Costa, L. F., Penso, M. A., Conceição, M. I. G., Junqueira, E. L., Meneses, F. F. F., \& Stroher, L. M. (2014). Violências e violências: As relações familiares do adolescente ofensor sexual. In L. C. A. Williams \& L. F. Habigzang (Eds.), Crianças e adolescentes vítimas de violência: Prevenção, avaliação e intervenção (pp. 125-142). Curitiba: Juruá.

Costa, L. F., Ribeiro, A., Junqueira, E. L., Meneses, F. F. F., \& Stroher, L. M. C. (2011). Grupo multifamiliar com adolescentes ofensores sexuais. Psico, 42 (4), 450-456.

Cunneen, C., \& Luke, G. (2007). Recidivism and the effectiveness of criminal justice interventions: Juvenile offenders and post release support. Current Issues in Criminal Justice, 19(2), 197-210.

Daly, K., Bouhours, B., Broadhurst, R. G., \& Loh, N. (2013). Youth sex offending, recidivism and restorative justice: Comparing court and conference cases. Australian \& New Zealand Journal of Criminology, 46(2), 241-267.

Dalton, J. H., Elias, M. J., \& Wandersman J. (2007). Community psychology: Linking individuals and communities. Belmont, California: Thomsom Wadsworth.

De Antoni, C., Barone, L. R., \& Koller, S. H. (2004). Violência e pobreza: um estudo sobre vulnerabilidade e resiliência familiar. In D. D. Dell'Aglio, S. H. Koller \& M. A. M. Yunes (Eds.), Resiliência e psicologia positiva: interfaces do risco à proteção (pp. 141171). São Paulo: Casa do Psicólogo.

Dell'Aglio, D. D., \& Nardi, F. L. (2010). Delinquência juvenil: Uma revisão teórica. Acta Colombiana de Psicologia, 13(2), 69-77.

Demo, P. (2004). Pesquisa e construção do conhecimento: Metodologia científica no 
caminho de Habermas. Rio de Janeiro, Brasil: Tempo Brasileiro.

Denzin, N. K., \& Lincoln. Y. S. (2011). The sage handbook of qualitative research. Londres, Inglaterra: Sage Publications.

Dessen, M. A., \& Cerqueira-Silva, S. (2009). Desenvolvendo sistemas de categorias com dados de entrevistas. In L. Weber, \& M. A. Dessen (Eds), Pesquisando a família: instrumentos para coleta e análise de dados (pp. 43-56). Curitiba: Juruá.

Dessen, M. A., \& Polônia, A. C. (2007). A Família e a Escola como contextos de desenvolvimento humano. Paidéia, 17(36), 21-32.

Espindola, G. A., \& Batista, V. (2013). Abuso sexual infanto-juvenil: A atuação do Programa Sentinela na cidade de Blumenau/SC. Psicologia: Ciência e Profissão, 33 (3), 596-611.

Esteves de Vasconcellos, M. J. (2012). Pensamento sistêmico: o novo paradigma da ciência. Campinas: Papirus.

Farrington, D. P., Loeber, R., \& Jolliffe, D. (2008). The age crime curve in reported offending. In R. Loeber, D. P. Farrington, S. Loeber \& H. R. White (Eds.), Violence and serious theft: Development and prediction from childhood to adulthood. New York: Routledge.

Finkelhor, D. \& Browne, A. (1985). The traumatic impact of child sexual abuse: A conceptualization. American Journal of Orthopsychiatry, 55(4), 530-541.

Fishman, H. C. (1996). Tratando adolescentes com problemas: Uma abordagem da terapia familiar. Porto Alegre: Artes Médicas.

Gee, D. G., Devilly, G. J., \& Ward, T. (2004). The content of sexual fantasies for sexual offenders. Sexual Abuse: Journal of Research and Treatment, 16, 315-331.

Gil, A. C. (1999). Métodos e técnicas de pesquisa social. São Paulo: Atlas.

Gomes, H. S. R. (1986). Terapia de Família. Psicologia: Ciência e Profissão, 6(2), 29-32. 
Grisante, P. C., \& Aiello, A. L. R. (2012). Interações familiares: observação de diferentes subsistemas em família com uma criança com Síndrome de Down. Revista Brasileira de Educação Especial, 18(2), 195-212.

Habigzang, L. F., Azevedo, G. A., Koller S. H., \& Machado P. X. (2006). Fatores de risco e de proteção na rede de atendimento a crianças e adolescentes vítimas de violência sexual. Psicologia: Reflexão e Crítica, 19, 379-386.

Habigzang, L. F., Ramos, M. S., \& Koller, S. (2011). A revelação de abuso sexual: As medidas adotadas pela rede de apoio. Psicologia: Teoria e Pesquisa, 27(4), 467-473.

Harris, A. J., \& Cudmore, R. (2016). Community experience with public sex ofender registries in the United States: A national survey. Criminal Justice Policy Review, 1, 122.

Harris, A. J., Walfield, S. M., Shields, R. T., \& Letourneau, E. J. (2015). Collateral consequences of juvenile sex offender registration and notification: Results from a survey of treatment providers. Sexual Abuse: Journal of Research and Treatment, 02, 122.

Harris, P. W., Lockwood, B., \& Mengers, L. (2009). A CJCA white paper: Defining and measuring recidivism [White paper]. Retrieved from http://www.cjca.net.

Hatzenberger, R., Habigzang, L. F., \& Koller, S. H. (2012). Análise das percepções que meninas vítimas de violência sexual têm de si, dos outros e do futuro: tríade cognitiva. In L. F. Habigzang \& S. H. Koller (Eds.), Violência contra crianças e adolescentes: Teoria, pesquisa e prática (pp. 69-79). Porto Alegre: Artmed.

Heiman, M. (2002). Helping parents address their child's sexual behavior problems. Journal of Child Sexual Abuse, 10(3), 35-57.

Hempel, I., Buck, N., Cima, M., \& Van-Marle, H. (2013). Review of risk assessment instruments for juvenile sex offenders: What is next? International Journal of Offender 
Therapy and Comparative Criminology, 57(2), 208-228.

Hershkowitz, I. (2014). Sexually intrusive behavior among alleged CSA male victims: A prospective study. Sexual Abuse: Journal of Research and Treatment, 26(3) 291-305.

Hunter, J. A. (2012a). Patterns of sexual offending in juveniles and risk factors. In E. P. Ryan, J. A. Hunter, \& D. C. Murrie, Juvenile sex offenders: A guide to evaluation and treatment for mental health professionals (pp. 34-53). New York: Oxford University Press.

Hunter, J. A. (2012b). Management and treatment methodos. In E. P. Ryan, J. A. Hunter, \& D. C. Murrie, Juvenile sex offenders: A guide to evaluation and treatment for mental health professionals (pp. 175-192). New York: Oxford University Press.

Hunter, J. A., \& Figueredo, A. J. (2000). The influence of personality and history of sexual victimization in the prediction of juvenile perpetrated child molestation. Behavior Modification, 24(2), 241-264.

Hunter, J. A., Hazelwood, R. R., \& Slesinger, D. (2000). Academic journal juvenileperpetrated sex crimes: Patterns of offending and predictors of violence. Journal of Family Violence, 15, 81-93.

Hunter, J. A., Ram, N. e Ryback, R. (2008). Use of satiation therapy in the treatment of adolescent-manifest sexual interest in male children: A single-case, repeated measures design. Clinical Case Studies, 7, 54-74.

IBGE (2015). Instituto Brasileiro de Geografia e Estatística. Recuperado em 21 de outubro de 2015, em http://ces.ibge.gov.br/base-de-dados/metadados/ministerio-da$\underline{\text { saude/sistema-de-informacoes-de-agravos-de-notificacao-sinan }}$

Japiassú, H., \& Marcondes, D. (2006). Dicionário básico de Filosofia. $4^{\text {a }}$ ed. Rio de Janeiro: Jorge Zahar.

Jones, C. D., Chancey, R., Lowe L. A., \& Risler, E. A. (2010). Residential treatment for 
sexually abusive youth: An assessment of treatment outcomes. Research on Social Work Practice, 20(2), 172-182.

Jones, S. (2015). Parentes of adolescents who have sexually offended. Providing support and coping with the experience. Journal of Interpersonal Violence, 30(8), 1299-1321.

Kahhale, E. M. P. (2001). Subsídios para reflexão sobre sexualidade na adolescência. In A. M. B. Bock, O. Furtado, \& M. L. T. Teixeira, Psicologia sócio-histórica: Uma perspectiva crítica em psicologia (pp. 179-91). São Paulo: Cortez.

Kemper, T. S., \& Kistner, J. A. (2007). Offense history and recidivism in three victim-agebased groups of juvenile sex offenders. Sexual Abuse: Journal of Research and Treatment, 19, 409-424.

Kjellgren, C., Wassberg, A., Carlberg, M., Langström, N., \& Svedin, C. G. (2006). Adolescent sexual offenders: a total survey of referrals to Social Services in Sweden and subgroup characteristics. Sexual Abuse: Journal of Research and Treatment, 18(4), 35772.

Krahé, B., Tomaszewska, P., Kuyper, L., \& Vanwesenbeeck, I. (2014). Prevalence of sexual aggression among young people in Europe: A review of the evidence from $27 \mathrm{EU}$ countries. Aggression and Violent Behavior, 19, 545-558.

Lambie, I., \& Johnston E. (2015). "I couldn't do it to a kid knowing what it did to me": The narratives of male sexual abuse victims' resiliency to sexually offending. International Journal of Offender Therapy and Comparative Criminology, 11, 1-22.

Langström, N., \& Grann, M. (2000). Risk for criminal recidivism among young sex offenders. Journal of Interpersonal Violence, 15, 855-871.

Latzman, N., Viljoen, J., Scalora, M., \& Ullman, D. (2011). Sexual offending in adolescence: a comparison of sibling offenders and nonsibling offenders across domains of risk and treatment need. Journal of Child Sexual Abuse, 20, 245-263. 
Letourneau, E. J., \& Miner, M. H. (2005). Juvenile sex offenders: A case against the legal and clinical status quo. Sexual Abuse: Journal of Research and Treatment, 17, 293-312.

LeVine, R. A. (1988). Human parental care: Universal goals, cultural strategies, individual behavior. In M. A. LeVine, P. M. Miller, \& M. M. West (Eds.), Parental behavior in diverse societies. New directions for child development. $N^{o} 40:$ The Jossey-Bass social and behavioral sciences series. San Francisco, CA: Jossey-Bass, Inc.

Lowenstein, L. (2006). Aspects of young sex abusers: A review of literature concerning sex abusers (1996-2004). Clinical Psychology and Psychotherapy, 13, 47-55.

Machado, M. T. (2003). A proteção constitucional de crianças e adolescentes e os direitos humanos. Barueri: Manole.

Marra, M. M. (2015). Do espaço privado para o público: construções narrativas com famílias em situação de abuso sexual. Tese de Doutorado. Universidade de Brasília: Brasil.

Marshall, W., \& Marshall, L. (2000). The origins of sexual offending. Trauma, Violence \& Abuse, 3, 250-263.

Maruschi, M. C., Estevão, R., \& Bazon, M. R. (2012). Risco de persistência na conduta infracional em adolescentes: estudo exploratório. Estudos de Psicologia Campinas, 29, 679-687.

Minayo, M. C. S. (2005). Laços perigosos entre machismo e violência. Ciência \& Saúde Coletiva, 10(1), 18-34.

McCuish, E. C., Cale, J., \& Corrado, R. R. (2015). Abuse experiences of family members, child maltreatment and development of sex offending among incarcerated adolescent males: Differences between adolescent sex offenders and adolescent non-sex offenders. International Journal of Offender Therapy and Comparative Criminology, 17(3), 1-23.

McLoyd, V. C. (1998). Socioeconomic disadvantage and child development. American 
Psychologist, 53(2), 185-204.

Meng Chu, C., \& Thomas, S. D. M. (2010). Adolescent sexual offenders: The relationship between typology and recidivism. Sexual Abuse: Journal of Research and Treatment, $22,218-233$.

Miner, M. H., Robinson, B. E., Knight, R. A., Berg, D., Romine, R. S., \& Netland, J. (2010). Understanding sexual perpetration against children: Effects of attachment style, interpersonal involvement, and hypersexuality. Sexual Abuse: Journal of Research and Treatment, 22(1), 58-77.

Minuchin, S. (1982). Famílias: funcionamento e tratamento. Porto Alegre: Artes Médicas.

Minuchin, S. (1985). Families and individual development: Provocations form the field of family therapy. Child Development, 56, 289-302.

Monte, F. F. C., Sampaio, L. R., Rosa-Filho, J. S. \& Barbosa, L. S. (2011). Adolescentes autores de atos infracionais: psicologia moral e legislação. Psicologia \& Sociedade,23(1), 125-134.

Morin, E. (2008). O método: a natureza da natureza. (Trad. I. Heineberg). Porto Alegre: Sulina.

Muñoz, R. F., Cuijpers, F., Smit, F., Barrera, A. Z., \& Leykin, Y. (2010). Prevention of major depression. Annual Review of Clinical Psychology, 6, 181-212.

Murrie, D. C. (2012). Assessment instruments for juveniles who sexually offend. In E. P. Ryan, J. A. Hunter, \& D. C. Murrie, Juvenile sex offenders: A guide to evaluation and treatment for mental health professionals (pp. 161-174). New York: Oxford University Press.

Murta, S. G. (2011). Aproximando ciência e comunidade: difusão de programas de habilidades sociais baseados em evidências. In A. Del Prette, \& Z. A. Del Prette (Eds.), Habilidades sociais: intervenções efetivas em grupo (pp. 83-114). São Paulo: Casa do 
Psicólogo.

Nahum, D., \& Brewer, M. M. (2004). Multi-family group therapy for sexually abusive youth. Journal of Child and Sex Abuse, 13(3-4), 215-243.

Olds, D., Henderson, C. R., Jr., Cole, R, Eckenrode, J., Kitzman, H., Luckey, D. et al. (1998). Long-term effects of nurse home visitation on children's criminal and antisocial behavior: 15-year follow-up of a randomized controlled trial. Journal of the American Medical Association, 280, 1238-1244.

Oliver, B. E. (2007). Three steps to reducing child molestation by adolescents. Child Abuse \& Neglect, 31, 683-689.

Outeiral, J. O. (2003). Adolescer: estudos revisados sobre adolescência. Rio de Janeiro: Revinter.

Paixão, A. C. W., \& Deslandes, S. F. (2010). Análise das políticas públicas de enfrentamento da violência sexual infanto-juvenil. Saúde e Sociedade, 19(3), 114-126.

Pasian, M. S., Faleiros, J. M., Bazon, M. R., \& C. Lacharité, (2013) Negligência infantil: a modalidade mais recorrente de maus-tratos. Pensando Famílias, 17(2), 61-70.

Penn, G. (2002). Análise Semiótica de imagens paradas. In M. W. Bauer, \& G. Gaskell (Eds), Pesquisa qualitativa com texto, imagem e som. Um manual prático (pp. 319-342). Petrópolis: Editora Vozes.

Penso, M. A., Conceição, M. I. G., Costa, L. F. \& Carreteiro, T. C. O. C. (2012). Jovens pedem socorro: o adolescente que praticou ato infracional e o adolescente que cometeu ofensa sexual. Brasília: Universa.

Penso, M. A., Costa, L. F., \& Sudbrack, M. F. (2008). A transmissão transgeracional no estudo da relação adolescentes, drogas e ato infracional. In M. A. Penso, \& L .F. Costa, Transmissão geracional em diferentes contextos: da pesquisa à intervenção (pp. 143164). São Paulo: Summus. 
Penso, M. A., \& Neves, V. L. (2008). Abuso sexual infantil e transgeracionalidade. In M. A. Penso, \& L .F. Costa, Transmissão geracional em diferentes contextos: da pesquisa à intervenção (pp. 123-142). São Paulo: Summus.

Pincolini, A. M. F., \& Hutz, C. S. (2014). Abusadores sexuais adultos e adolescentes no sul do Brasil: Pesquisa em denúncias e sentenças judiciais. Temas em Psicologia, 22(2), 301311.

Porto, M. S. G. (2010). Sociologia da violência: do conceito às representações sociais. Brasília: Francis.

Prentky, R. A., Burgess, A. W., Rokous, F., Lee, A., Hartman, C., Ressler, R. et al. (1989). The presumptive role of fantasy in serial sexual homicide. American Journal of Psychiatry, 146, 887-891.

Prentky, R. A., \& Righthand, S. (2003). Juvenile sex offender assessment protocol-II (JSOAP-II): Manual. Washington, DC. United States Department of Justice.

Ramos, M. E. E., \& Oliveira, K. D. (2008). Transgeracionalidade percebida nos casos de maus-tratos. In M. A. Penso, \& L .F. Costa, Transmissão geracional em diferentes contextos: da pesquisa à intervenção (pp. 99-122). São Paulo: Summus.

Rasmussen, L. A. (1999). Factors related to recidivism among juvenile sexual offenders. Sexual Abuse: Journal of Research and Treatment, 11, 69-85.

Rodgers, K. B., \& McGuire, J. K. (2012). Adolescent sexual risk and multiple contexts: Interpersonal violence, parenting and poverty. Journal of Interpersonal Violence, 27(11), 2091-2107.

Ryan, E. P. (2012). Changing perceptions of juvenile sexual offending in society and legal system. In E. P. Ryan, J. A. Hunter, \& D. C. Murrie, Juvenile sex offenders: A guide to evaluation and treatment for mental health professionals (pp. 1-20). New York: Oxford University Press. 
Ryan, G. (2005). Preventing violence and trauma in the next generation. Journal of Interpersonal Violence, 20, 132-141.

Santos, V. A. (2010). As medidas protetivas e a garantia de direitos na perspectiva de famílias em situação de violência sexual intrafamiliar. Tese de Doutorado. Universidade de Brasília: Brasil.

Secretaria de Direitos Humanos da Presidência da República (SDH-PR) (2013). Plano Nacional de Enfrentamento da Violência Sexual contra Crianças e Adolescentes. Brasília: SDH-PR.

Secretaria de Direitos Humanos da Presidência da República (SDH-PR) (2015). Disque 100. Recuperado em 15 dezembro de 2015 de http://direitoshumanos.gov.br.

Secretaria de Estado de Saúde do Distrito Federal (SESDF) (2015). Recuperado em 27 de outubro de 2015 de http://www.saude.df.gov.br/sobre-a-secretaria/hospitais-e$\underline{\text { regionais/506-centro-de-orientacao-medico-psicopedagogica-compp.html . }}$

Sell, M., \& Ostermann, A. C. (2015). A construção da significação da experiência do abuso sexual infantil através da narrativa: uma perspectiva interacional. Documentação e Estudos em Linguística Teórica e Aplicada,31(2), 307-332.

Seto, M. C., Kjellgren, C., Priebe, G., Mossige, S., Svedin C. G., \& Langström, N. (2010). Sexual coercion experience and sexually coercive behavior: A population study of Swedish and Norwegian male youth. Child Maltreatment 15(3) 219-228.

Seto, M. C., \& Lalumiére, M. L. (2010). What is so special about male adolescent sexual offending? A review and test of explanations through meta-analysis. Psychological Bulletin, 136, 526-575.

Smith, S., Wampler R., Jones J., \& Reifman A (2005). Differences in self-report measures by adolescent sex offender risk group. International Journal of Offender Therapy and Comparative Criminology, 49(1), 82-106. 
Spice, A., Viljoen J. L., Latzman N. E., Scalora, M. J., \& Ullman, D. (2012). Risk and protective factors for recidivism among juveniles who have offended sexually. Sexual Abuse: A Journal of Research and Treatment, 25(4), 347-369.

UNICEF (2011). O direito de ser adolescente: Oportunidade para reduzir vulnerabilidades e superar desigualdades. Fundo das Nações Unidas para a Infância. Brasília: UNICEF.

Valente, F. P. R., \& Lopes de Oliveira, M. C. S. (2015). Para além da punição: (Re)construindo o conceito de responsabilização socioeducativa. Estudos e Pesquisa em Psicologia 15(3), 853-870.

Vandiver, D. M. (2006). A prospective analysis of juvenile male sex offenders: Characteristics and recidivism rates as adults. Journal of Interpersonal Violence, 21(5),673-688.

Vara da Infância e da Juventude do Distrito Federal (VIJ-DF) (2012). Dados consolidados 2011. Recuperado em 14 de maio de 2014: http//www.tjdft.jus.br/trib/vij/docVij/estatis/2010/vij_viol sex_pdf.

Ward, T., Gannon. T. A., \& Birgden, A. (2007). Human rights and treatment of sex offenders. Sex Abuse, 19, 195-216.

Weisz J. R., Sandler I. N., Durlak J. A., \& Anton B. S. (2005) Promoting and protecting youth mental health through evidence-based prevention and treatment. American Psychologist, 60(6), 628-648.

Weitzman, J. (1985). Engaging the severely dysfunctional family in treatment: Basic considerations. Family Process, 24, 473-485.

Wijk, A. Ph., Bullens, R. A. R, \& Vermeiren, R. R. (2007). Criminal profiles of violent juvenile sex and violent juvenile non-sex offenders: An explorative longitudinal study. Journal of Interpersonal Violence, 22(10) 1340-1355.

Worley, K. B., Church, J. K., \& Clemmons, J. C. (2012). Parents of adolescents who have 
committed sexual offenses: Characteristics, challenges, and interventions. Clinical Child Psychology and Psychiatry, 17(3), 432-448.

Worling, J. R. (2012). The assessment and treatment of deviant sexual arousal with adolescents who have offended sexually. Journal of Sexual Aggression, 18, 36-63.

Worling, J. R., Bookalam, D., \& Litteljohn, A. (2012). Prospective validity of the estimate of risk of adolescent sexual offense recidivism (ERASOR). Sexual Abuse: A Journal of Research and Treatment, 24(3), 203-223.

Worling, J. R., \& Curwen, T. (2001). Estimate of Risk of Adolescent Sexual Offense Recidivism (ERASOR; Version 2.0). In M. C. Calder (Ed.), Juveniles and children who sexually abuse: Frameworks for assessment (pp. 372-397). Lyme Regis, UK: Russell House. Available at www.erasor.org.

Worling, J. R., \& Langton, C. M. (2012). Assessment and treatment of adolescents who sexually offend: Clinical issues and implications for secure settings. Criminal Justice and Behavior, 39, 814-840.

Worling, J. R., \& Langström, N. (2003). Assessment of criminal recidivism risk with adolescents who have offended sexually: A review. Trauma, Violence \& Abuse, 4, 341361.

Zankman, S. \& Bonomo, J. (2004). Working with parents to reduce juvenile sex offender recidivism. Journal of Child Sexual Abuse, 13(4), 139-156.

Zimring, F. (2004). An American Travesty: Legal Responsibility to Adolescent Sexual Offending. Chicago: University of Chicago Press. 
ANEXOS 


\section{ANEXO I - Ficha de notificação - SINAN (1º modelo)}

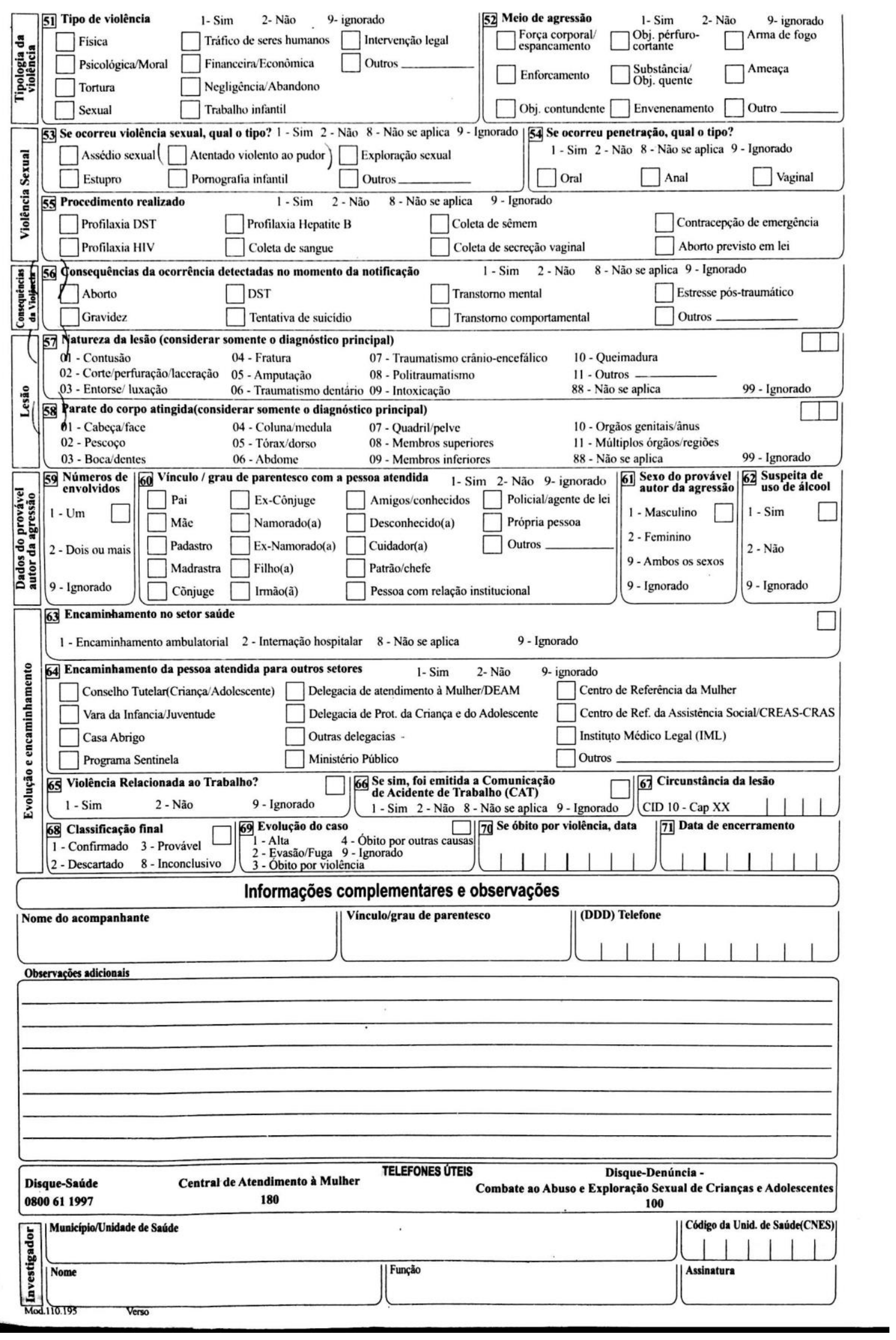




\section{ANEXO II - Ficha de notificação - SINAN ( $2^{\circ}$ modelo $)$}

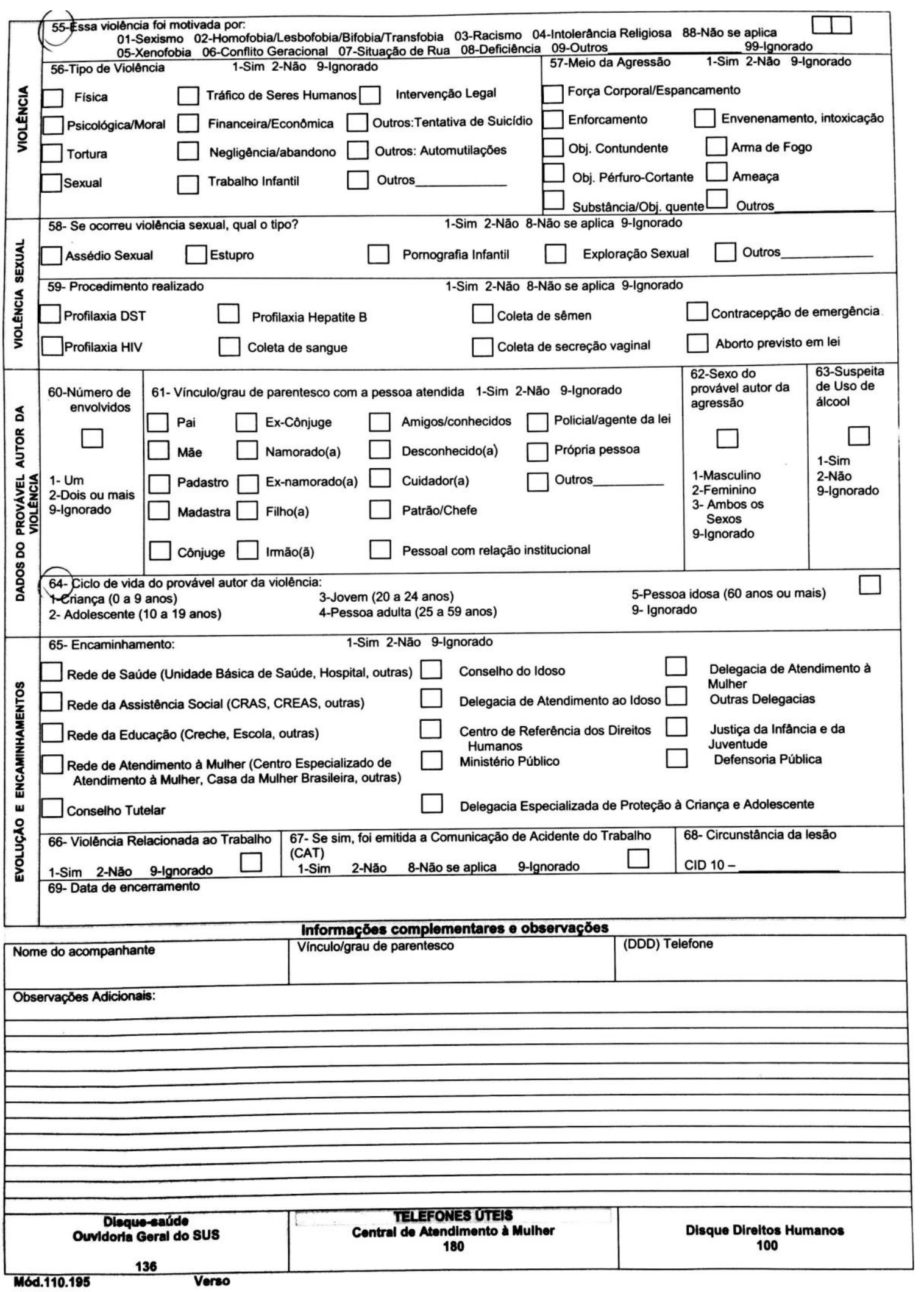




\section{ANEXO III - Entrevista semiestruturada}

Entrevista para o GM

Data:

Nome:

DN: RA:

Profissionais responsáveis:

01. Sujeito

02. Descrição do caso

03. Perfil da família

04. Figura de referência nesta família

05. Atividades de lazer em família

06. Com quem esta família pode contar

07. Genograma

08. Ecomapa

09. Situação atual do sujeito

10. Condição socioeconômica da família

11. Perfil da vítima

12. Perfil da família da vítima

13. Condição socioeconômica da família da vítima

14. Situação atual da família

15. Perfil da violência (foi denunciado, onde, por quem)

16. Perfil das ações básicas (quando houve denúncia, quem é a figura de referência no CT, VIJ, DPCA)

17. Julgamento e sentença

18. Observações 


\section{ANEXO IV - ERASOR}

\section{ERASOR 2.0 \\ ESTIMATIVA DE RISCO DE REINCIDÊNCIA DE AGRESSÃO SEXUAL EM ADOLESCENTES}

James R. Worling \& Tracey Curwen (SAFE-T Program, Thistletown Regional Centre, Canada)

Ricardo G. Barroso, PhD \& Celina Manita, PhD (Versão Portuguesa)

Este é um SUMÁRIO do instrumento de avaliação. APENAS VÁLIDO SE a cotação for feita segundo o formulário de codificação em anexo. O nome do adolescente e a data de avaliação deverão ser anotados na página 1.

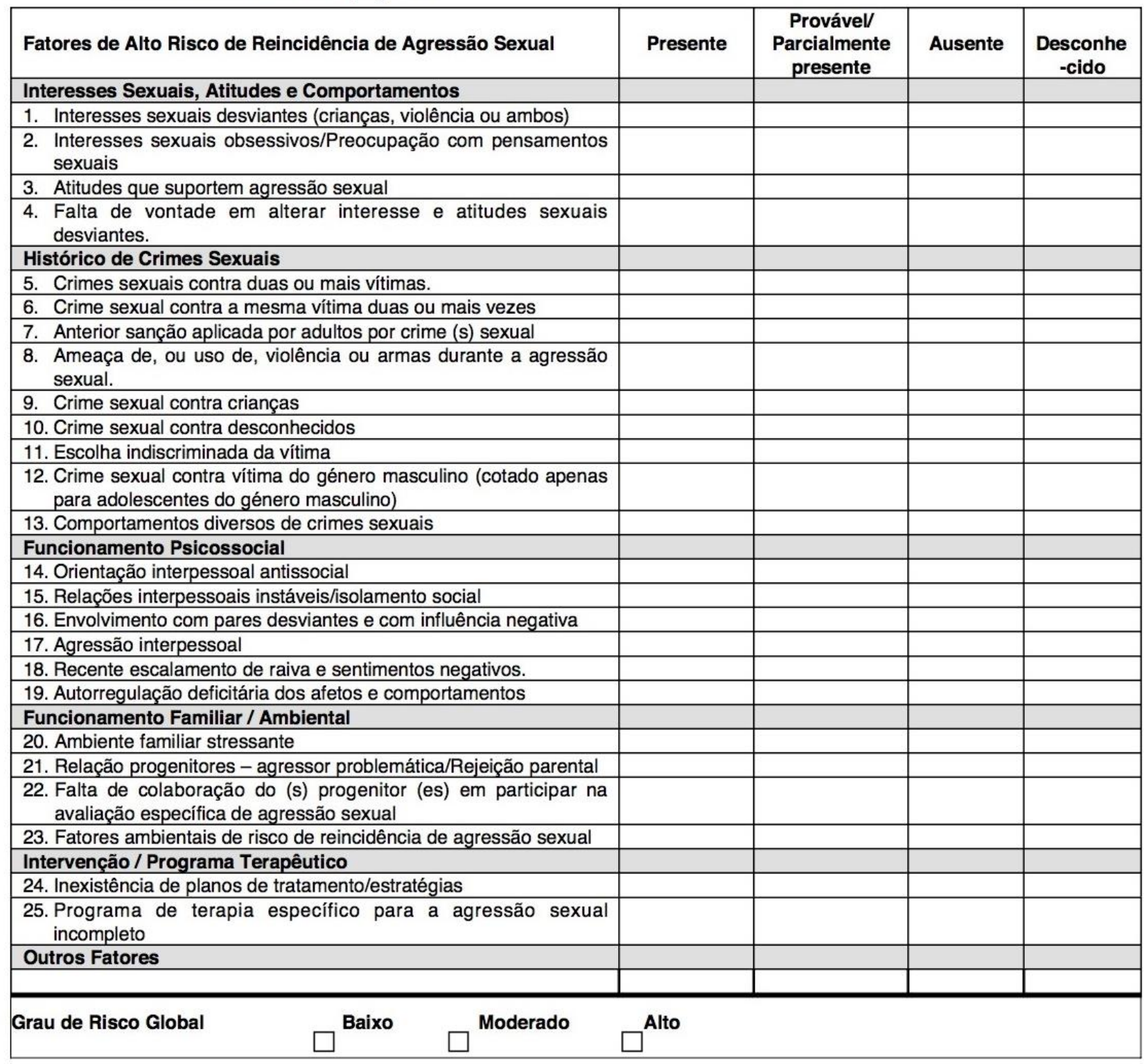


ANEXO V - Figura

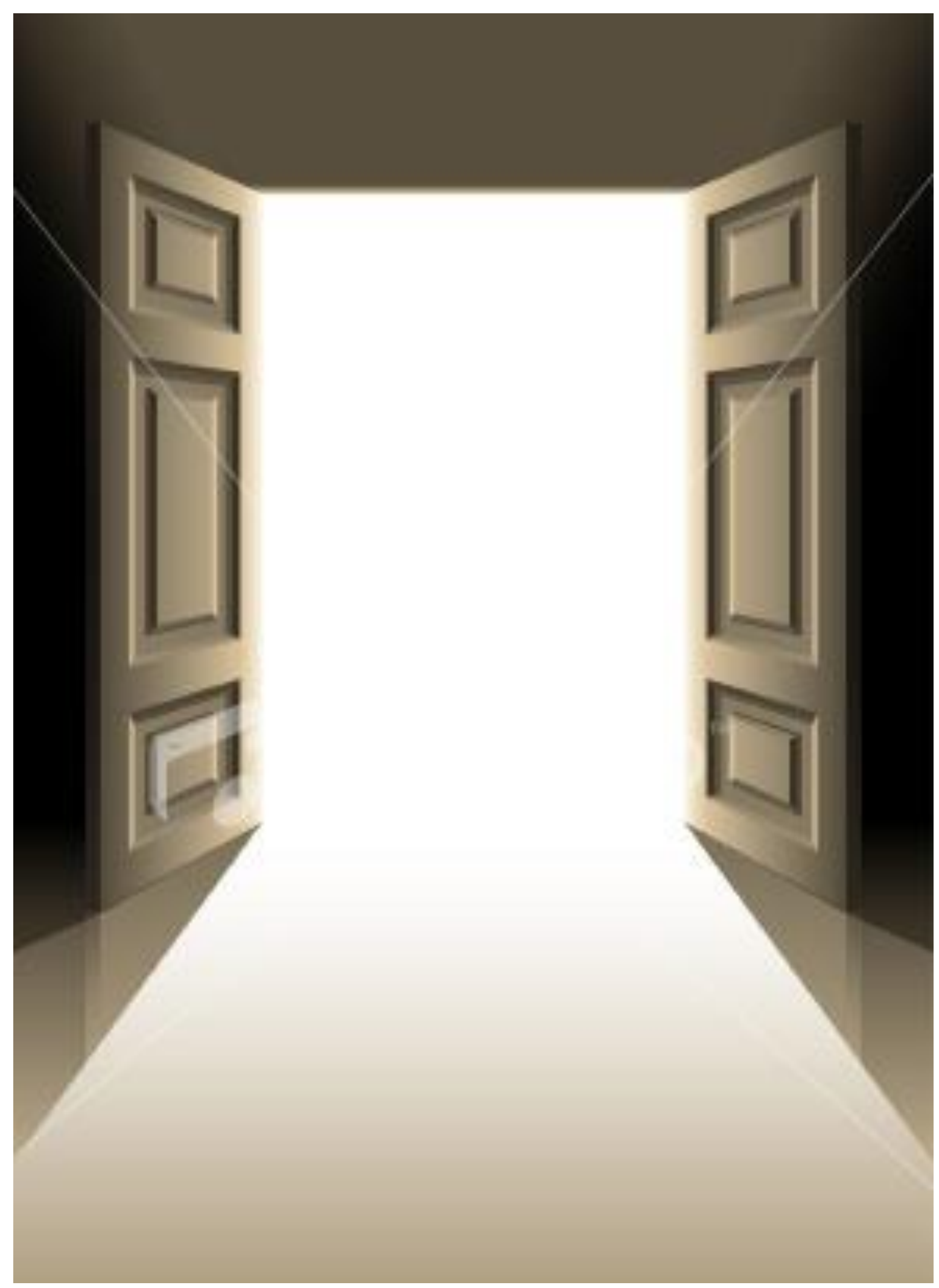

